\author{
Mon ograph \\ urn:1sid:zoobank.org:pub:85AF63D9-5E9E-4CE0-AEC6-6F7CC8C4D375
}

\title{
Rhaetian (Late Triassic) ostracods (Crustacea, Ostracoda) from the offshore prolongation of the North Dobrogean Orogen into the Romanian Black Sea shelf
}

\author{
Marie-Béatrice FOREL ${ }^{1, *}$ \& Eugen GRĂDINARU 2,* \\ ${ }^{1}$ Muséum national d'histoire naturelle, CR2P, MNHN-CNRS-SU, \\ 8 rue Buffon (CP38), 75005 Paris, France. \\ ${ }^{2}$ Department of Geology, Faculty of Geology and Geophysics, University of Bucharest, \\ Bd. Bălcescu Nicolae 1, RO-010041 Bucharest, Romania. \\ *Co-corresponding authors: marie-beatrice.forel@mnhn.fr; eugen.gradinaru@g.unibuc.ro \\ ${ }^{1}$ urn:lsid:zoobank.org:author:063C1F7E-6D26-48F9-A8B1-2AFA496B5FB8 \\ ${ }^{2}$ urn:1sid:zoobank.org:author:DE8A275A-486D-478F-9333-0FE0F7D30A78
}

\begin{abstract}
The present study evaluates the significance of Triassic ostracods from the Romanian Black Sea shelf as part of a project for the understanding of the palaeoceanographical evolution of the offshore extension of the North Dobrogean Orogen. The drill core CM31, sampled from the borehole 817 Lebăda Vest drilled on the western Romanian portion of the Black Sea shelf, contains sediments of Rhaetian, Late Triassic age. The taxonomy of ostracods obtained is discussed and adds to the scientific understanding of marine ostracods during the Rhaetian stage. We document 72 species, of which seven are new: Histriabairdia pontuseuxinusensis Forel gen. et sp. nov., Bairdiacypris argonautaii Forel sp. nov., Ceratobairdia? akhilleusi Forel sp. nov., Isobythocypris atalantella Forel sp. nov., Petasobairdia amazonella Forel sp. nov., Paracypris ovidi Forel sp. nov. and Pseudomacrocypris? kerabani Forel sp. nov. Histriabairdia Forel gen. nov. is introduced to accommodate species of the Triassic-Jurassic interval previously attributed to the modern genus Anchistrocheles. These assemblages point to an outer shelf environmental with relatively normal marine oxygenation. The oldest occurrence of Pokornyopsis, found in this material, indicates that this forerunner of modern troglobitic ostracods may not have been troglobitic in the Triassic.
\end{abstract}

Keywords. Ostracods, Rhaetian, Late Triassic, Romanian Black Sea shelf.

Forel M.-B. \& Grădinaru E. 2020. Rhaetian (Late Triassic) ostracods (Crustacea, Ostracoda) from the offshore prolongation of the North Dobrogean Orogen into the Romanian Black Sea shelf. European Journal of Taxonomy 727: 1-83. https://doi.org/10.5852/ejt.2020.727.1183

\section{Introduction}

Ostracods are millimetre-size crustaceans that are significant components of the meiofauna. Recent ostracods live in various aquatic environments, from temporary freshwater ponds to hydrothermal 
sources or cold methane seep sites (e.g., Horne et al. 2002; Maddocks 2005; Yasuhara et al. 2018), the deepest known living species occurring at a depth of $9307 \mathrm{~m}$ in the northwestern Pacific (Brandão et al. 2019). Some ostracods are commensal on diverse invertebrates or sea turtles (e.g., de Vos 1953; Maddocks 1968; Tanaka \& Hayashi 2019). Ostracods were marine and benthic during the Early Palaeozoic (e.g., Salas et al. 2007; Siveter 2008), colonized the water column during the Silurian (e.g., Siveter 1984; Siveter \& Vannier 1990; Siveter et al. 1991; Vannier \& Abe 1992) and non-marine water bodies during the Carboniferous (e.g., Williams et al. 2006; Bennett 2008; Bennett et al. 2012). Marine ostracods greatly suffered during the most devastating mass extinction at the end of the Permian about $252 \mathrm{Ma}$ (see Crasquin \& Forel 2014 for a summary). Ostracods from the Permian-Triassic transition have been intensively investigated since the 1970's (e.g., Wang 1978; Shi \& Chen 1987; Yi 2004; Forel et al. 2013a; Crasquin et al. 2017), allowing for the identification of several survival modes in the aftermath of the crisis (e.g., Forel et al. 2013b, 2020a; Gliwa et al. 2020). Following the high amplitude diversity fluctuations of the Early Triassic, the recovery of ostracods is considered as complete by the Anisian, Middle Triassic (e.g., Crasquin-Soleau et al. 2007; Crasquin \& Forel 2014). This stage witnessed the acme of a high-diversity plateau that further developed until the brink of the end-Triassic extinction, as well as the radiation of numerous taxa, including Cytheruridae and typically Triassic ornate Bairdiidae (see Forel \& Crasquin 2020 for a summary). The Triassic was also a turning point in the evolutionary history of ostracods with the replacement of the Palaeozoic evolutionary fauna by the Meso-Cenozoic one (e.g., McKenzie 1982; Crasquin-Soleau et al. 2007; Crasquin \& Forel 2014). However, this period remains enigmatic due to the temporary dominance of Platycopida, the explosive radiation of ornate Bairdiidae (e.g., Kollmann 1960, 1963; Bolz 1971a, 1971b; Kristan-Tollmann 1978) and the residual occurrence of Palaeozoic taxa in deep waters up to the Carnian, Late Triassic (e.g., Forel et al. 2019a). In that sense, the Triassic ostracod fauna is transitional as it is neither Palaeozoic, nor truly Mesozoic. One of the major future challenges of ostracodology will be to reach a stable consensus on the classification of Bairdiidae, known from the Middle Ordovician (e.g., Becker 2001) up to today in all marine ecosystems, and to complete the 'morphological phylogeny' of Permian and Triassic ornate genera proposed by Forel \& Crasquin (2020).

The Rhaetian, at the very end of the Late Triassic, witnessed the acme of several families, including Bairdiidae, Cytheruridae and Healdiidae, as well as the earliest known occurrences of Progonocytheridae and Cytheridae (Forel \& Crasquin 2020). This stage precedes the end-Triassic extinction event, so the characterisation of assemblages during the Rhaetian is pivotal to providing a baseline to study this key interval. Rhaetian ostracods are known from localities in Alaska (Sohn 1987), Argentina (Ballent 1994; Riccardi et al. 2004), Australia (Kristan-Tollmann 1986a; Dépêche \& Crasquin-Soleau 1992; KristanTollmann \& Gramann 1992), Austria (Kollmann 1960, 1963; Kristan-Tollmann 1970, 1971a, 1971b, 1972; Bolz 1969, 1971a, 1971b; Urlichs 1972; Kristan-Tollmann et al. 1991a; Mette \& Mohtat-Aghai 1999; Mette et al. 2012), Denmark (Christensen 1962), Germany (Dreyer 1967; Kozur 1968), India (Kristan-Tollmann \& Gupta 1988), Iraq (Al-Khahab \& Al-Halawachi 2018), Iran (Kristan-Tollmann et al. 1979, 1980), Ireland (Ainsworth \& Horton 1986; Ainsworth 1989, 1990; Ainsworth et al. 1989; Rutherford \& Ainsworth 1989), Italy (Belloni 1960; Crasquin-Soleau et al. 2000), UK (Jones 1894; Anderson 1964; Bate 1978; Boomer et al. 1999; Swift 2003) and Vietnam (Patte 1926). Here we report on the first known assemblage of marine ostracods of Rhaetian age from the Romanian Black Sea shelf. The taxonomy of the marine ostracod assemblages from CM31 drill core 817LV retrieved on the Romanian Black Sea shelf is discussed, adding to the scientific understanding of marine ostracods during the Rhaetian stage, Late Triassic. Their taxonomy is described and discussed, including the earliest known occurrences of Pokornyopsis Kozur, 1974 as well as the youngest known record of Rectonariidae. This new material allows us to introduce the new genus Histriabairdia gen. nov. to accommodate Triassic and Jurassic species previously attributed to the extended genus Anchistrocheles Brady \& Norman, 1889. 
Geological and stratigraphic framework (by Eugen Grădinaru)

Geological setting

The North Dobrogean Orogen apparently structurally extends eastwards into the Romanian sector of the western Black Sea shelf (Fig. 1). The Triassic rocks are widely represented in the onshore area of the North Dobrogean Orogen, with the largest areal extension and the complete stratigraphic development in the Tulcea Unit (Grădinaru 1995, 2000). However, the Triassic rocks have been found and sampled

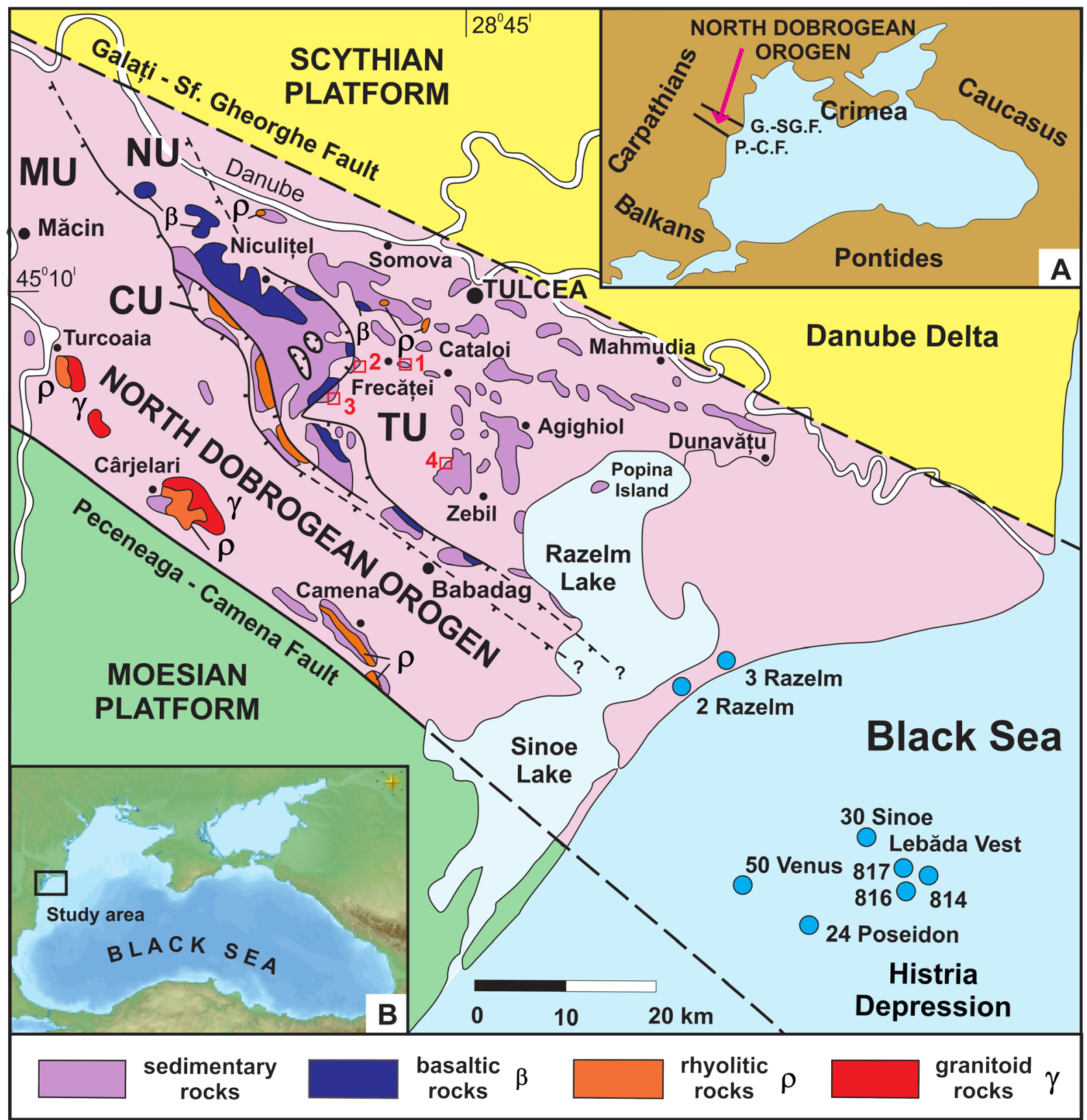

Fig. 1. Tectonostratigraphic map of the onshore North Dobrogean Orogen showing the distribution of Triassic rocks and the location of the boreholes on the western Black Sea shelf that drilled into the Triassic. $\mathrm{MU}=$ Măcin Unit; CU = Consul Unit; NU = Niculițel Unit; TU = Tulcea Unit (modified and completed after Grădinaru 2000). 1-4: onshore occurrences of the Rhaetian at Frecăței, Poșta, Izvoarele and Rândunica, respectively. Inset map A shows the location of the North Dobrogean Orogen. Inset map B shows the location of the study area on the western Black Sea shelf. 
only in a few boreholes drilled on the Romanian Western Black Sea shelf. Grădinaru et al. (1989) provided the most complete report on the Triassic drilled in the Romanian Black Sea shelf based on the available data at that time.

The study of the Triassic rocks drilled on the Romanian Black Sea shelf is of key importance for any discussion concerning the offshore extension of the North Dobrogean Orogen. However, far too little attention has been paid in the published literature (e.g., Cătuneanu \& Maftei 1994; T,ambrea et al. 2002; Dinu et al. 2005) to its lithological development, microfacies features, biostratigraphy and fossil content, and to generate a well-constrained chronostratigraphic framework of the Triassic rocks drilled in the Romanian sector of the Black Sea western shelf.

The lithofacies of some Triassic rocks drilled on the Romanian western shelf of the Black Sea are comparable to those of some of the onshore North Dobrogean Triassic successions, such as those sampled in the boreholes 2 Razelm, 3 Razelm, 50 Venus or 24 Poseidon. In other cases, such as for the boreholes 814, 816 and 817 Lebăda Vest, and 30 Sinoe, the lithofacies of the sampled Triassic rocks do not match with any of the known onshore North Dobrogean Triassic successions. Apart from the two boreholes 2 Razelm and 3 Razelm, that were drilled on the shore of the Black Sea, all other boreholes are located in the area of the Histria Depression (e.g., Dinu et al. 1989, 2005).

In the present contribution, we focus on the Triassic rocks sampled in the borehole 817 Lebăda Vest (817 LV), which provides important data regarding their lithology, microfacies, and especially concerning the outstanding content of microfossils, ostracods (studied in the present paper), foraminifers (Luka Gale, pers. com.) and conodonts (Tea Kolar-Jurkovsek, pers. com.), relevant for the Rhaetian (Late Triassic) age. Macrofossils, especially brachiopods and rare bivalves, also constrain the Rhaetian age.

The borehole $817 \mathrm{LV}$ was drilled into $5 \mathrm{~m}$ thick Triassic limestone, from 2620 to $2625 \mathrm{~m}$, where it stopped (Fig. 2a). A 2 m thick drill core labelled CM31 (2623 to $2625 \mathrm{~m}$ ) has been sampled and its ostracod content is scrutinized here. The limestone is light grey-cream in colour, compact and hard, with splintery cracking and thin veins of calcite or black clay. The last two meters of the higher core sample CM30 (2611 to $2618 \mathrm{~m}$ ) contain numerous limestone clasts, $\mathrm{cm}$ to dm in size, sub-angular to subrounded, together with clasts of volcanic origin, grey-greenish in colour, packed in slickensided Middle Jurassic black argillites.

There are several lines of evidence arguing that the Triassic drilled in the Lebada Vest field is allochthonous, being represented by exotic blocks of variable sizes, from centimeters (clasts) up to tens of meters (olistoliths) embedded in Middle Jurassic dark black argillites often slickensided. The microfacially homogenous $2 \mathrm{~m}$ thick limestone of the drill core CM31, which doesn't display any evident sedimentary structure, e.g., bedding, was drilled more or less along the bedding. This conclusion is also supported by the homogeneity of the ostracod assemblages retrieved from the different intervals of this drill core.

In the last decades, some authors have arbitrarily included the Romanian western Black Sea shelf in the so-called 'Odessa Shelf' (e.g., Okay \& Tüysüz 1999; Kalvoda et al. 2002; Stephenson \& Schellart 2010; Okay et al. 2015). The 'Odessa Shelf', in the meaning of the above-mentioned authors, is not only an incorrect geographical term but it is also not justified for both geological and geopolitical reasons. Intriguingly, the offshore extensions into the Black Sea shelf of the North Dobrogean Orogen and of the Moesian Platform, respectively, are assigned to the so-called 'Odessa Shelf'. However, the proper Odessa Shelf is underlain solely by the East European Platform at the north and by the Scythian Platform at the south (Starostenko et al. 2015: fig. 1), and it is fully located on the Ukraine Shelf.

There is a current tectonic model according to which the Istanbul Terrane/Zone allegedly rifted off from the Romanian/Ukrainian conjugate margin that is dubbed as the 'Odessa Shelf', and which was translated 

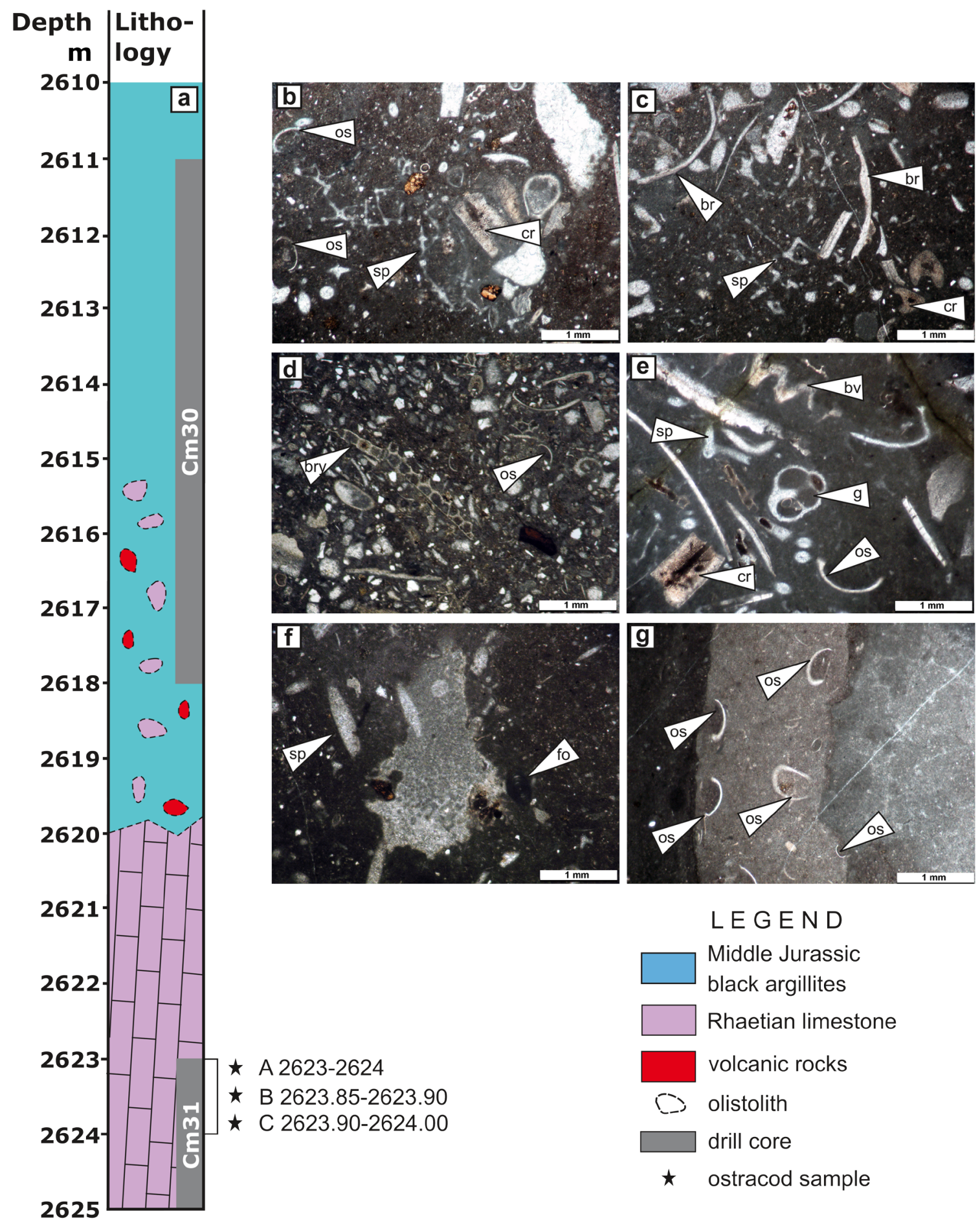

\section{LE GEN D}

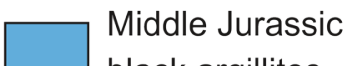

black argillites

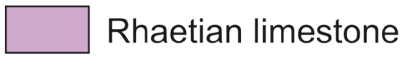

volcanic rocks

S.) olistolith

$\square$ drill core

$\star \quad$ ostracod sample

Fig. 2. Lithostratigraphic log of the lowest section in the borehole $817 \mathrm{LV}$ [a], showing the depth level of drill core CM31 into the allochthonous Rhaetian limestone, Romanian Western Black Sea shelf, and the position of the samples (A, B and C) investigated for ostracods; [b-g] microfacies features in the brachiopod-bearing bioclastic wackestone: [b-e] skeletal grains of calcified sponge spicules and fragments of hexactinellid sponges (sp), echinoderm debris (cr), brachiopods (br), bivalves (bv), ostracods (os) and bryozoans (bry); [f] digitate cavity filled with micropeloidal sediment prior to the precipitation of the drusy cement - note the calcified sponge spicules (sp) and foraminifers (fo); [g] burrow infill with micrite containing ostracods (os). 
southwards, opening the Western Black Sea basin during the Cretaceous (e.g., Okay et al. 1994, 2018; Okay \& Tüysüz 1999; Okay \& Görür 2007; Tari et al. 2015; Tüysüz 2018). The Triassic succesion of the Istanbul Terrane/Zone, as described by Yurttaş-Özdemir (1971), Assereto (1972), Fantini Sestini (1988), Okay et al. (2015) and Gaetani (2016), has no counterpart, neither by its lithology nor by its ammonoid and brachiopod faunas, in the Triassic successions of any of the geological units supposedly underlying the 'Odessa Shelf', i.e., in the Triassic successions of the Scythian and Moesian platforms and particularly in the Triassic successions of the North Dobrogean Orogen. Moreover, the Triassic successions drilled in the Histria Depression, located in the Romanian Western Black Sea shelf in the eastward offshore prolongation of the North Dobrogean Orogen (Grădinaru et al. 1989; Cătuneanu \& Maftei 1994), are not to be found in the Istanbul Terrane/Zone.

The confusing term of the 'Odessa Shelf' ignores the highly differing geological structure and evolution of each of the tectonic units wrongly aggregated into it. In their suggested palaeotectonic reconstruction for the Triassic, Okay \& Nikishin (2015: figs 6-7), to justify their assertion that the Istanbul Terrane/ Zone was the counterpart Turkish margin of the 'Odessa Shelf', referred to their alleged 'IstanbulGebze and Dobrogea Triassic series', in which a fully unsuitable stratigraphic column is illustrated for the Triassic of North Dobrogea. On the contrary, for the Palaeozoic, Okay \& Nikishin (2015: fig. 4) and Okay \& Topuz (2017: fig. 4) considered that the Istanbul Terrane/Zone was the counterpart of Moesia, although the Palaeozoic successions underlying the Triassic in North Dobrogea are entirely different from the Palaeozoic sedimentary series underlying the Triassic of Moesia (e.g., Seghedi 2012: fig. 11 vs fig.18). So, amazingly, the Istanbul Terrane/Zone is considered akin either to the North Dobrogean Orogen for the Triassic or to Moesia for the Palaeozoic, although all of these geological units have nothing in common as regards their geological history and tectonic structure. The North Dobrogean Orogen and Moesia, which were coalesced into the actual tectonic configuration only during the Early Cretaceous, were not contiguous between them or with the Istanbul Terrane/Zone, neither in the puzzle of the Palaeozoic palaeogeography nor in that of the Triassic palaeogeography.

The dichotomy of the Triassic and Palaeozoic palaeotectonic reconstructions done by the abovementioned authors just originates from the wrong term of the 'Odessa Shelf'as being the supposed conjugate margin of the Istanbul Terrane/Zone.

In conclusion, the tectonic model advocating that the Western Black Sea basin opened as a back-arc basin in the Late Cretaceous separating the Pontides from mainland Eurasia (Okay et al. 2020) is completely counterproductive in any attempts to palinspastically reconstruct the palaeogeographies of the Triassic and of the Palaeozoic, respectively, for the geological units surrounding the Western Black Sea basin, as it wholly ignores the kinematic evolution of the regions lying westwards of the Black Sea (Grădinaru \& Gaetani 2019).

\section{Microfacies and depositional environment}

Microfacially, the brachiopod-bearing biomicritic limestone in the drill core of CM31 from borehole $817 \mathrm{LV}$ is a burrowed bioclastic wackestone, locally a packstone. The micrite matrix, as seen in thin sections, contains predominantly skeletal grains of benthic organisms, such as sponges, echinoderm debris, brachiopods, bivalves, ostracods, foraminifers, bryozoans and rare juvenile gastropods. Skeletal particles change in frequency, but they are dominated by crinoids as well as echinoid plates and spines, to which calcified sponge spicules and fragments from the fine skeletal network of hexactinellid sponges are added. Foraminifera are represented by rare Involutina, Ophthalmidium and encrusting ?Bullopora. Some of the bioclasts are bioeroded, but there are abundant bioclasts that are not affected by bioerosion. The microfacies is characterized by common burrowing and some burrows contain ostracod shells (Fig. 2b-g). Rare radiolarians are present. The micrite contains very small skeletal debris forming a finely bioclastic matrix. Digitate cavities are filled with early intrusion of the micropeloidal sediment 
into cavities prior to the precipitation of drusy cement, creating normal and reverse grading and geopetal structures.

The depositional environment corresponds to a deep shelf environment that is indicated by the skeletal grains of benthic organisms. The sedimentation took place in a quiet-water, low-energy environment below the fair-weather base but within the reach of storm waves. Rare grains with ferruginous coatings indicate reworking. The diverse shelly fauna and the abundance of brachiopods and echinoderms indicate normal marine, stenohaline, well-oxygenated water conditions (cf. Flügel 2004).

\section{Biostratigraphic data}

A rich foraminiferal assemblage and rare conodonts have been obtained from residue obtained by cold acetolysis with buffered 5\% acetic acid (Grădinaru et al. 1989) including Ammobaculites tzankovi (Trifonova, 1962), Cyclogyra cf. pachygyra (Gümbel, 1869), Gaudryina triassica Trifonova, 1962, G. kelleri Tappan, 1955, Gaudryinella kotlensis Trifonova, 1967, Glomospira charoides (Jones \& Parker, 1860), Jaculella cf. expansa (Plummer, 1945), Oberhauserella norica Fuchs, 1968, Oberhauserellidae (diverse new species), Plagioraphe tornata Kristan-Tollmann, 1973, Pseudobolivina tornata KristanTollmann, 1973, Reophax rudis Kristan-Tollmann, 1964, Tetrataxis sp., Trochammina alpina KristanTollmann, 1964, Norigondolella steinbergensis (Mosher, 1968) and Oncodella paucidentata (Mostler, 1967). They are indicative of the Steinbergensis conodont biozone, base Rhaetian (Krystyn 1987).

Identified brachiopods are Euxinella anatolica (Bittner, 1891), Fissirhynchia fissicostata (Suess, 1854) and Rhaetina pyriformis (Suess, 1854). Specimens of the bivalve Pteria? aff. gansingensis (v. Alberti, 1864) have also been retrieved.

\section{Onshore-offshore correlation of the Rhaetian}

On the onshore area of the North Dobrogean Orogen, the Upper Triassic sedimentary deposits are present only in the Tulcea Unit (Grădinaru 1995, 2000). Due to the large coverage by the Quaternary loess, the occurrences of the Upper Triassic, including here both the Norian and the Rhaetian, are scanty and limited to only a few small areas. The Rhaetian deposits are biostratigraphically documented by the coquina calcareous siltstones with Otapiria marshalli alpina Zapfe, 1973 occurring one km eastwards of Frecăței village on the right side of the Telița valley (Grădinaru 1984; Mirăuță et al. 1993). Potentially, the Rhaetian also exists in the Movila Verde hill area, westwards of Poșta village, and in the Coasta lui Nicu area, northwards of Izvoarele village, respectively, both located in the innermost part of the Tulcea Unit which is tectonically overthrusted by the Niculițel Unit (Grădinaru 1984). The Rhaetian is represented in both areas by light-grey reddish limestones and grey claystones. Crumpled reddish biomicritic limestones with Otapiria occur south of Rândunica (Congaz) village, on the left side of the Telița valley, in the same region from where Mirăuță \& Gheorghian (1975) described Norian conodonts and foraminifers.

Therefore, at the present state of knowledge, the light grey-cream biomicritic limestone of drill core CM31 from borehole $817 \mathrm{LV}$ has no counterpart from a lithological point of view within the Rhaetian occurring in the onshore North Dobrogean Orogen.

It is of high relevance for palaeotectonic and palaeogeographic interpretations to highlight the close lithological and palaeobiological affinities of the allochthonous Rhaetian limestone drilled on the Romanian Black Sea shelf with the Rhaetian brachiopod-bearing biomicritic limestone within the KichikSarman olistolith embedded in the Lower Eski-Orda Formation, located on the Alma-Bodrak interfluve, east of Bakhchisaray, in the Mountainous Crimea (Korchagin et al. 2003), and also within other Crimean exotic limestone blocks (Kotlyar et al. 1999). The brachiopod fauna of the allochthonous Rhaetian limestone in drill core CM31 contains similar species to that of the allochthonous Rhaetian limestone in the Mountainous Crimea as recorded by Dagys (1974). The close affinities of the allochthonous 
Rhaetian limestone drilled on the Romanian western Black Sea shelf, in the eastwards prolongation of the North Dobrogea Orogen, with the Rhaetian limestone in the Crimean exotic blocks may open the way for constructive insights into the palaeotectonic and palaeogeographic relationships between the regions of North Dobrogea and Mountainous Crimea.

\section{Material and methods}

The studied material comes from the $2 \mathrm{~m}$ thick drill core CM31 (2623m to $2625 \mathrm{~m}$ ) of borehole 817 LV. Three limestone samples, labelled CM31A to CM31C (Fig. 2a), have been processed using the hot acetolysis technique (Lethiers \& Crasquin-Soleau 1988; Crasquin-Soleau et al. 2005) for ostracod extraction.

In the present contribution, we follow the general classification of ostracods of Moore (1961), Becker (2002) and Horne et al. (2002). The taxonomy of Cytheroidea is based on the revision of Whatley \& Boomer (2000) and that of Bythocytheridae follows Schornikov (1990).

Seventy-two species distributed across 30 genera and 13 families have been identified during this investigation of drill core CM31 (Table 1). As detailed above, several taxonomic issues are still pending regarding Triassic ostracods, so all species are illustrated to enable future comparisons (Figs 5-13); those left in open nomenclature or referred to already known species are only discussed when necessary. In our study, most of the specimens occur as complete carapaces, which hampers the observation of internal structures on the valves. Following Maddocks (2015), the degree of slope of the antero-dorsal and postero-dorsal margins were measured on external lateral views of the carapace/valves, with 0 being horizontal. As discussed for instance in Maddocks (1969), Bairdiidae are highly homeomorphic ostracods for which diagnostic features are complex to characterize and describe. To objectivize descriptions, characters are quantified as much as possible and the length convention of carapaces/valves is as follow: $<0.40$ very small, $0.40-0.50$ small, $0.50-0.70$ medium, $0.70-1.00$ large, $>1.0$ very large.

In height/length diagrams (Figs 3-4), all right and left valves are distinguished, following for instance Urlichs (1971), Harloff (1993) and Forel et al. (2020b). The accurate delimitation of ontogenetic stages in the fossil record is often difficult because fossil assemblages represent time-averaging of populations from different environments or seasons (e.g., Morales-Ramirez \& Jakob 2008) and because the smallest (i.e., youngest) specimens are only seldomly found for diverse reasons including fossilisation, picking and identification. To overcome this issue, the delineation of ontogenetic stages has been performed by producing Kernel density maps (Gaussian Kernel distribution, columns $=100$, rows $=100$, radius $=15$ to 30) using PAST software (Hammer et al. 2001; Hammer \& Harper 2005). For each species that counts at least 15 specimens (from this paper and the literature), Kernel density maps discriminate density patterns of individuals that correspond to different ontogenetical stages, with the hypothesis that the largest specimens are adults. Successive instars of ten species are recognized and described here (Figs 3-4).

\section{Material repository}

All type and figured specimens are deposited in the Micropalaeontology collections of the Muséum national d'histoire naturelle, Paris, France (MNHN) under catalogue numbers MNHN.F.F63181MNHN.F.F63331.

\section{Anatomical abbreviations}

$\mathrm{AB}=$ anterior border

$\mathrm{ADB}=$ antero-dorsal border

AMS = adductor muscle scars

AVB $=$ antero-ventral border 
Table 1 (continued on next page). Taxonomic list of all ostracod species identified from drill core CM31, Black Sea, Romanian Continental Shelf, Rhaetian, Late Triassic.

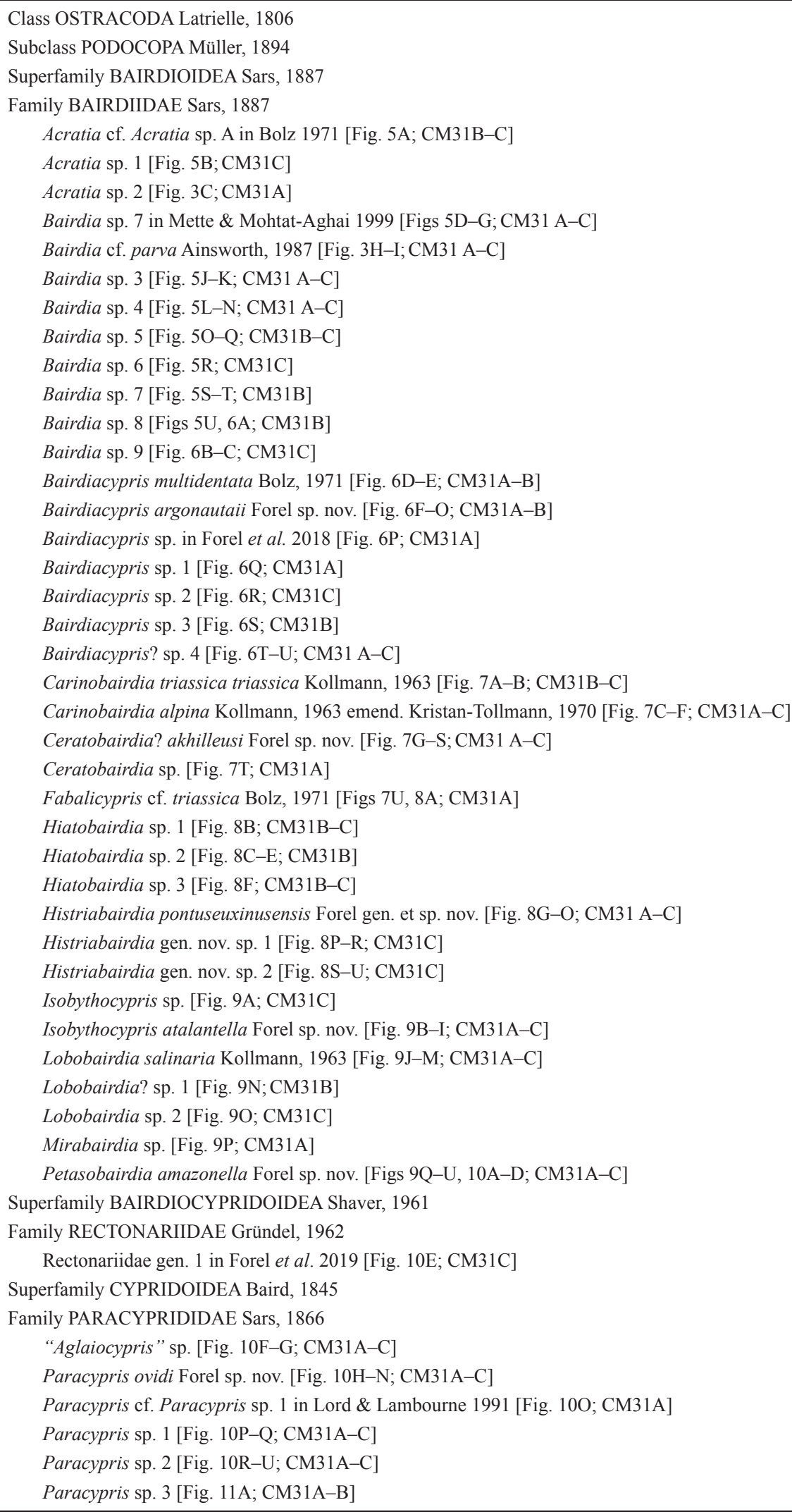


Table 1 (continued). Taxonomic list of all ostracod species identified from drill core CM31, Black Sea, Romanian Continental Shelf, Rhaetian, Late Triassic.

Family PONTOCYPRIDIDAE Müller, 1894

Pseudomacrocypris? kerabani Forel sp. nov. [Fig. 11B-G; CM31A-C]

Pseudomacrocypris? sp. [Fig. 11H; CM31B-C]

Superfamily CYTHEROIDEA Baird, 1850

Family BYTHOCYTHERIDAE Sars, 1866

Praebythoceratina sp. [Fig. 11I-J; CM31B-C]

Triassocythere sp. [Fig. 11K; CM31C]

Family CYTHERURIDAE Müller, 1894

Subfamily CYTHERURINAE Müller, 1894

Judahella andrusovi Kozur \& Bolz in Bunza \& Kozur, 1971 [Fig. 11L-M; CM31A-C]

Cytheruridae gen. et sp. indet. [Fig. 11N-P; CM31B-C]

Superfamily MACROCYPRIDOIDEA Müller, 1912

Family MACROCYPRIDIDAE Sars, 1866

Praemacrocypris sp. [Fig. 11Q; CM31B]

Superfamily SIGILLIOIDEA Mandelstam, 1960

Family SIGILLIIDAE Mandelstam, 1960

Cardobairdia sp. 1 [Fig. 11R-S; CM31A-B]

Cardobairdia sp. 2 [Figs 11T-U, 12A-C; CM31A-C]

Cardobairdia sp. 3 [Fig. 12D-F; CM31A, C]

Cardobairdia sp. 4 [Fig. 12G-K; CM31A-B]

Cardobairdia sp. 5 [Fig. 12L; CM31C]

Cardobairdia? sp. 6 [Fig. 12M; CM31B]

Suborder METACOPINA Sylvester-Bradley, 1961

Superfamily HEALDIOIDEA Harlton, 1933

Family HEALDIIDAE Harlton, 1933

Hungarella koessenensis (Mette \& Mohtat-Aghai, 1999) [Fig. 12N-Q; CM31A-C]

Hungarella sp. 1 [Fig. 12R; CM31B]

Hungarella? sp. 2 [Fig. 12S; CM31C]

Order PLATYCOPIDA Sars, 1866

Suborder PLATYCOPINA Sars, 1866

Superfamily CYTHERELLOIDEA Sars, 1866

Family CYTHERELLIDAE Sars, 1866

Cytherelloidea cf. modesta Apostolescu, 1959 [Fig. 12T; CM31B-C]

Cytherelloidea? sp. [Fig. 12U; CM31A]

Leviella sp. [Fig. 13A; CM31C]

Subclass MYODOCOPA Sars, 1866

Order HALOCYPRIDA Dana, 1853

Suborder HALOCYPRIDINA Dana, 1853

Superfamily THAUMATOCYPRIDOIDEA Müller, 1906

Family THAUMATOCYPRIDIDAE Müller, 1906

Pokornyopsis sp. 1 [Fig. 13B-C; CM31B]

Pokornyopsis? sp. 2 [Fig. 13D-E; CM31A]

Pokornyopsis sp. 3 [Fig. 13F; CM31A]

Order MYODOCOPIDA Sars, 1866

Suborder MYODOCOPINA Sars, 1866

Superfamily CYLINDROLEBERIDOIDEA Müller, 1906

Family CYLINDROLEBERIDIDAE Müller, 1906

Hungaroleberis sp. 1 [Fig. 13G-I; CM31A-C]

Hungaroleberis sp. 2 [Fig. 13J-L; CM31A]

Superfamily POLYCOPOIDEA Sars, 1866

Family POLYCOPIDAE Sars, 1866

Polycope sp. 1 [Fig. 13M; CM31A-C]

Polycope sp. 2 [Fig. 13N; CM31A-C]

Polycope sp. 3 [Fig. 13O; CM31A-B]

Polycope sp. 4 [Fig. 13P; CM31C] 

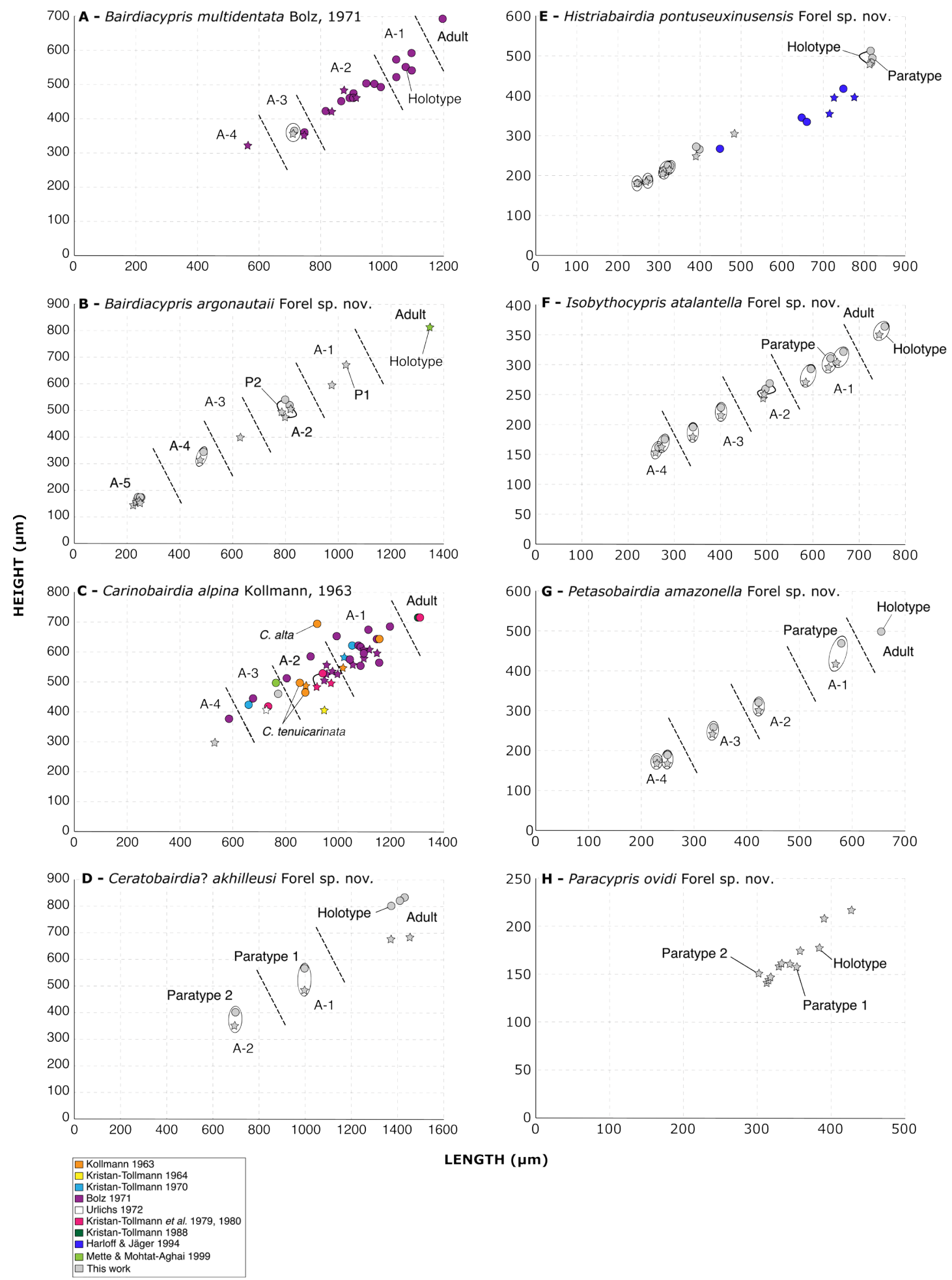

LENGTH $(\mu \mathrm{m})$

Fig. 3. Height/length scatter plots of species from borehole 817 Lebăda Vest, drill core CM31, western portion of Black Sea shelf, Rhaetian, Late Triassic. In all diagrams, the dimensions of right (stars) and left (circles) valves of complete carapaces are shown separately and circled or linked. P1 = paratype 1; P2 = paratype 2. A. Bairdiacypris multidentata Bolz, 1971. B. Bairdiacypris argonautaii Forel sp. nov. C. Carinobairdia alpina Kollmann, 1963. D. Ceratobairdia? akhilleusi Forel sp. nov. E. Histriabairdia pontuseuxinusensis Forel gen. et sp. nov. F. Isobythocypris atalantella Forel sp. nov. G. Petasobairdia amazonella Forel sp. nov. H. Paracypris ovidi Forel sp. nov. 


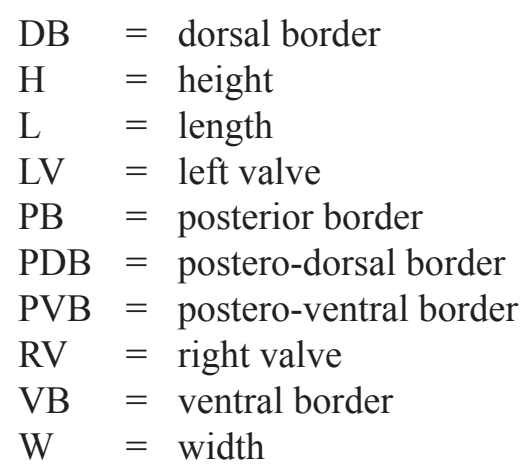

\section{Results}

Systematic palaeontology (by Marie-Béatrice Forel)

Class Ostracoda Latreille, 1806

Subclass Podocopa Müller, 1894

Superfamily Bairdioidea Sars, 1887

Family Bairdiidae Sars, 1887

\section{Subfamilial and generic discussions}

Taxonomy of Bairdiidae: state of the art and consensus

Bairdiidae have been components of marine ostracod assemblages from the Ordovician (e.g., Moore 1961; Salas 2007) to present days (e.g., Brady 1880, 1890; Maddocks 1969, 1975; Titterton \& Whatley 1988; Brandão 2008). Their generally simple and smooth carapaces make it complex to accurately discriminate taxa and describe their diagnostic characters. This homeomorphy led to the unreliability of their taxonomy, as has often been discussed in the literature (e.g., Maddocks 1969; Malz 1988). Intense efforts have partly clarified the taxonomy of modern representatives of the 'Bairdia dynasty' (Malz 1988) with the establishment and/or revision of Neonesidea Maddocks, 1969, Paranesidea Maddocks, 1969, Bairdoppilata Coryell et al., 1935 and Triebelina van den Bold, 1946 (e.g., Maddocks
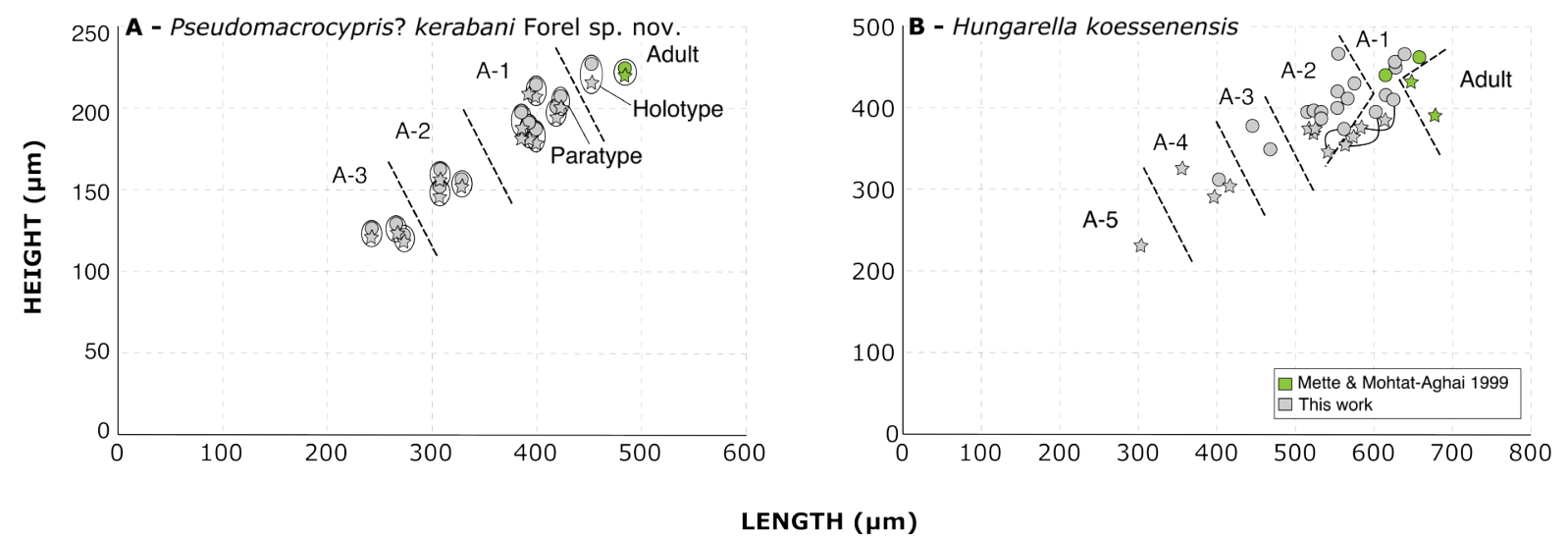

Fig. 4. Height/length scatter plots of species from borehole 817 Lebăda Vest, drill core CM31, western portion of Black Sea shelf, Rhaetian, Late Triassic. In all diagrams, the dimensions of right (stars) and left (circles) valves of complete carapaces are shown separately and circled or linked. A. Pseudomacrocypris? kerabani Forel sp. nov. B. Hungarella koessenensis (Mette \& Mohtat-Aghai, 1999). 
$1969,2013,2015)$. The diagnostic features of these genera are found in soft parts as well as carapaces, and recently the taxonomic potential of their chewing apparatus has been discussed (Maddocks 2013, 2018). Conversely, the classification of fossil Bairdiidae has not improved much since the 1960's, when Sohn (1960) and Kollmann $(1960,1963)$ clarified the classification of Palaeozoic and Triassic taxa, respectively. Although the taxonomic conclusions of these papers are disputed, it is agreed that Bairdia s. str. is restricted to the Palaeozoic and that "to include other forms under this name violates its morphologic and quite possibly its phyletic homogeneity" (Maddocks 1969: 1). Maddocks (1969) and all subsequent contributions deconstructed the widespread idea, termed 'heresy', that "the 'key' to relationships among Recent ostracod species is to be found in the soft parts, and that the carapace alone provides insufficient evidence for distinction of 'biologic' or 'natural' taxa". In the long evolutionary history of Bairdiidae, the Triassic period has been a turning point in recording the explosive diversification of ornate forms (e.g., Kollmann 1960, 1963; Kristan-Tollmann 1970, 1971a; Bolz 1971a, 1971b; Kozur 1971a, 1971b) that are still present in modern marine ecosystems, although less abundant and diverse (e.g., Brady 1870; Cabioch et al. 1986; Malz \& Lord 1988; Titterton \& Whatley 1988; Jellinek 1989; Maddocks \& Wouters 1990; M.-B. Forel, pers. obs. and work in progress). The classification of fossil and recent ornate Bairdiidae, defined as "small to medium-sized, thick-shelled, heavily ornamented forms, largely but not entirely restricted to reefal habitats" (Maddocks \& Wouters 1990: 173), has been debated since their descriptions, as was summarized for instance in Bolz (1971a, 1971b). Notwithstanding the problems we have encountered, we consider that it is beyond the scope and intention of this paper and its material to attempt a revision of the Bairdiidae at the subfamilial and generic levels. An attempt to introduce a phylogeny for Permian and Triassic genera has recently been proposed, describing two lineages (Ceratobairdia lineage and Abrobairdia lineage), both derived from Petasobairdia in the early Permian (Forel \& Crasquin 2020). Until this model is improved, we follow the generic scheme of Kollmann (1963) in considering primary ornamentation as a relevant generic character, considering that ornamentation is widely used as a generic marker, mutatis mutandis, for other families (e.g., Trachyleberididae: Moore 1961; Warne \& Whatley 2016) and often corresponds to morphologic features with diverse functions, some of which are genetically controlled (e.g., Liebau 1977; Keyser 1995). We furthermore follow the subfamilial scheme proposed by Maddocks (1969) in which most of the Triassic subfamilies created in the successive contributions of Kollmann and KristanTollmann are downgraded to the tribe level. We consider this inclusive scheme as the most reasonable to avoid artificial over-splitting.

\section{Taxonomic consensus on Bairdiacypris / Fabalicypris / Isobythocypris}

The original description of Fabalicypris Cooper, 1946 states that it is morphologically close to other bairdiids but differs from Bairdia McCoy, 1844 and Bairdiacypris Bradfield, 1935 in lacking a pronounced postero-dorsal slope and highly arched dorsal border. It is further differentiated from Bairdia by the lack of an acuminate posterior end. Fabalicypris also differs from Bairdiacypris in being more tumid and by the presence of a pronounced offset of the antero-ventral overlap (Cooper 1946). These elements are problematic, as they imply that Bairdia and Bairdiacypris should also differ by the presence of an antero-ventral overlap in Bairdia, which is not the case. In subsequent years, the validity of Fabalicypris has been discussed, leading to different schools of thought. The first one considers that the characters differentiating Bairdiacypris and Fabalicypris are highly variable and that Fabalicypris is a junior synonym of Bairdiacypris (e.g., Sohn 1983; Hoare et al. 1999). The second school of thought considers Fabalicypris as a subgenus of Bairdiacypris, described as "with overall carapace morphology of Bairdiacypris, but bairdiid shape more or less obscured; ventral overlap decreasing abruptly in anterior third to form offset or step-like process" (Becker 2001). Conversely, Bairdiacypris is described as "elongate bairdiid outline; dorsal margin tripartite, sometimes barely discernible; posterior end rounded" (Becker 2001). Here, we follow the first school of thought to avoid complicating the taxonomic situation of bairdiids until a complete revision of these ostracods. We therefore use the following diagnostic summaries provided by Ainsworth (1990): 
Table 2. Classification consensus for Bairdiacypris Bradfield, 1935, Fabalicypris Cooper, 1946 and Isobythocypris Apostolescu, 1959.

\begin{tabular}{cccc}
\hline & Lateral outline & Dorsal margin & Ventral offset \\
\hline Bairdiacypris & subovate-subtriangular & tripartite & absent \\
Fabalicypris & elongate subovate-elongate subtriangular & arched & present \\
Isobythocypris & subrectangular-elongate subrectangular & arched & absent \\
\hline
\end{tabular}

Bairdiacypris: "Carapace of medium to large size, subovate to subtriangular, laterally compressed in dorsal view. Anterior margin asymmetrically rounded, lower margin convex, upper margin straight. Posterior margin broadly rounded. Dorsal margin near straight to strongly arched. Ventral margin often with a well formed oral concavity in right valve. Hinge adont, short. Inner lamella moderately wide, with both anterior and posterior vestibules. Muscle scar pattern of several discrete spots" (Ainsworth 1990: 179).

Fabalicypris: "Carapace of medium to large size, elongate subovate to elongate subtriangular in lateral view. Anterior margin rounded. Posterior margin strongly asymmetrically rounded, near subtriangular. Dorsal margin generally evenly arched. Ventral margin straight, with a prominent oral concavity in right valve. Inner lamella moderately wide. Hinge adont" (Ainsworth 1990: 179).

Confusion may also arise for the distinction of Isobythocypris Apostolescu, 1959 from other bairdiids. The diagnosis of Isobythocypris is as follows: "Un genre de Bairdiidae caractérisé par sa carapace subréniforme et par sa charnière. Dans la valve droite, le système de fermeture consiste en deux proéminences de forme elliptique; dans la valve gauche, un sillon étroit et lisse, terminé à chaque extrémité par un alvéole" (Apostolescu 1959 : 807), which translates as "a genus of Bairdiidae characterized by its subreniform carapace and its hinge. In the right valve, the closing system consists of two elliptical protuberances; in the left valve, a narrow and smooth ridge, terminated by an alveole at each extremity". Ainsworth $(1989,1990)$ clarified the diagnosis of Isobythocypris as follows: "Carapace of medium to large size, subrectangular to elongate subrectangular. Inner lamella broad, especially anteriorly. Anterior and posterior vestibules moderately wide. Hinge lophodont" (Ainsworth 1989: 126, 1990: 179). In the present investigation, most of the specimens are present as complete carapaces or as valves with poorly preserved inner surface so that hingement was not accessible. The outer characters used here to distinguish Bairdiacypris, Fabalicypris and Isobythocypris are summarized in Table 2.

Subfamily Bairdiinae Sars, 1923

Genus Acratia Delo, 1930

\section{Type species}

Acratia typica Delo, 1930, by original designation.

Acratia cf. Acratia sp. A in Bolz 1971

Fig. 5A

\section{Material examined}

ROMANIA 1 complete carapace; Black Sea, Romanian Continental Shelf, borehole 817LV, sample CM31B; Rhaetian, Upper Triassic; MNHN.F.F63181 • 1 LV; same locality as for preceding but sample CM31C; Rhaetian, Upper Triassic; MNHN.F.F63341. 
Table 3. Dimensions of all specimens of Acratia cf. Acratia sp. A in Bolz 1971 (this paper).

\begin{tabular}{|c|c|c|c|c|}
\hline & Length $(\mu \mathrm{m})$ & Height $(\mu \mathrm{m})$ & $H / L$ & Reference \\
\hline$A$. sp. A (LV) & 1590 & 610 & 0.38 & Bolz (1971b) \\
\hline A. sp. A (LV) & 1110 & 450 & 0.40 & Bolz (1971b) \\
\hline$A . \mathbf{s p} . \mathbf{A}(\mathrm{RV})$ & 1380 & 550 & 0.40 & Bolz (1971b) \\
\hline $\begin{array}{c}\boldsymbol{A} . \mathbf{c f} . \boldsymbol{A} . \mathbf{s p} . \mathbf{A} \\
(\mathrm{LV} \text { of carapace) }\end{array}$ & 828 & 291 & 0.35 & This paper \\
\hline $\begin{array}{c}\boldsymbol{A} . \mathbf{c f} . \boldsymbol{A} . \mathbf{s p} . \mathbf{A} \\
(\mathrm{RV} \text { of carapace) }\end{array}$ & 828 & 280 & 0.34 & This paper \\
\hline
\end{tabular}

\section{Dimensions}

Bolz (1971b) provided measurements for two carapaces and a RV. Here we equate the measurements of carapaces with those of the larger LV to allow for comparisons (Table 3).

\section{Occurrence}

Romanian Continental Shelf, Black Sea, Rhaetian, Late Triassic (this paper).

\section{Remarks}

This species differs from Acratia sp. A in Bolz 1971b from the Norian-Rhaetian of the Northern Calcareous Alps (Bolz 1971b) in being slightly more elongate, having a more pronounced ventral concavity, a more angulate dorsal margin at LV and a rostrum located higher. The two species are nevertheless close morphologically as shown by the antero-dorsal offset of LV over RV. The complete carapace recovered here is slightly smaller than the specimens reported from Austria (Table 3 ) and could represent an immature juvenile. We cannot exclude that the observed differences relate to ontogeny, the antero-dorsal offset being a diagnostic character of the species. Acratia cf. Acratia sp. A in Bolz 1971 is also close to A. goemoeryi Kozur, 1970 from the Middle Triassic of Hungary (Kozur 1970). Forel et al. (2019a) plotted the H/L diagram of all known specimens of $A$. goemoeryi, in which the present specimen could correspond to a relatively young juvenile stage. Several isolated valves or poorly preserved carapaces of $A$. goemoeryi have been documented from the Middle Triassic and early Late Triassic, which do not allow for the observation of the possible dorsal offset visible in Acratia sp. A in Bolz 1971 and Acratia cf. Acratia sp. A in Bolz 1971. Furthermore, the ADB of RV is arched in A. goemoeryi while it is concave in the present material.

\section{Acratia sp. 1}

Fig. 5B

\section{Material examined}

ROMANIA • 1 RV; Black Sea, Romanian Continental Shelf, borehole 817LV, sample CM31C; Rhaetian, Upper Triassic; MNHN.F.F63182.

\section{Dimensions}

$\mathrm{L}=343 \mu \mathrm{m} ; \mathrm{H}=147 \mu \mathrm{m} ; \mathrm{H} / \mathrm{L}=0.43$.

\section{Occurrence}

Romanian Continental Shelf, Black Sea, Rhaetian, Upper Triassic (this paper). 


\section{Remarks}

The small dimensions of this specimen indicate that it may be an immature stage. However, its very rounded anterior margin and downward pointing posterior extremity preclude it from being attributed to any of the co-occurring species of Acratia. Acratia sp. 1 is close to Paracypris sp. 1 in Lord \& Lambourne 1991 from the Early Jurassic of Turkey (Lord \& Lambourne 1991) and to Paracypris cf. Paracypris sp. 1 in Lord \& Lambourne 1991 in the present paper (Fig. 10O). However, the small anteroventral concavity of the present specimen relates it to the genus Acratia. Acratia sp. 1 is also related to A. kollmanni Forel in Forel et al., 2019 from the Carnian, Late Triassic, of Turkey (Forel et al. 2019a) as shown by its anterior and posterior extremities being located very low, with a uniformly rounded dorsal margin. However, A. kollmanni is shorter and higher and has a more incised antero-ventral concavity.

Genus Bairdia McCoy, 1844

\section{Type species}

Bairdia curta McCoy, 1844, subsequently designated by Ulrich \& Bassler (1923).

Bairdia sp. 7 in Mette \& Mohtat-Aghai 1999

Fig. 5D-G

Bairdia sp. 7 - Mette \& Mohtat-Aghai 1999: pl. 4, figs 4-5.

\section{Material examined}

ROMANIA • 1 RV; Black Sea, Romanian Continental Shelf, borehole 817LV, sample CM31B; Rhaetian, Upper Triassic; MNHN.F.F63184 • 1 RV; same locality as for preceding but sample CM31A; Rhaetian, Upper Triassic; MNHN.F.F63185 - 1 LV; same locality as for preceding but sample CM31B; Rhaetian, Upper Triassic; MNHN.F.F63186 2 complete carapaces, 5 RV, $4 \mathrm{LV}$; same locality as for preceding but samples CM31A, CM31B and CM31C; Rhaetian, Upper Triassic; MNHN.F.F63342.

Fig. 5 (opposite page). SEM micrographs of ostracods from borehole 817 Lebăda Vest, drill core CM31, western portion of Black Sea shelf, Rhaetian, Late Triassic. All specimens are housed in the collections of the Muséum national d'histoire naturelle, Paris, France (MNHN). A. Acratia cf. Acratia sp. A in Bolz 1971, right lateral view of a carapace, sample CM31B (MNHN.F.F63181). B. Acratia sp. 1, external view of a right valve, sample CM31C (MNHN.F.F63182). C. Acratia sp. 2, right lateral view of a carapace, sample CM31A (MNHN.F.F63183). D-G. Bairdia sp. 7 in Mette \& Mohtat-Aghai 1999. D. External view of a right valve, sample CM31B (MNHN.F.F63184). E. External view of a right valve, sample CM31A (MNHN.F.F63185). F. External view of a left valve, sample CM31B (MNHN.F.F63186). G. Same specimen, inner view. H-I. Bairdia cf. parva Ainsworth, 1987. H. Right lateral view of a carapace, sample CM31B (MNHN.F.F63187). I. Right lateral view of a carapace, sample CM31B (MNHN.F.F63188). J-K. Bairdia sp. 3. J. Right lateral view of a carapace, sample CM31A (MNHN.F.F63189). K. Right lateral view of a carapace, sample CM31C (MNHN.F.F63190). L-N. Bairdia sp. 4. L. Right lateral view of a carapace, sample CM31C (MNHN.F.F63191). M. Right lateral view of a carapace, sample CM31B (MNHN.F.F63192). N. Same specimen, dorsal view. O-Q. Bairdia sp. 5. O. Right lateral view of a carapace, sample CM31C (MNHN.F.F63193). P. Same specimen, dorsal view. Q. Right lateral view of a carapace, sample CM31B (MNHN.F.F63194). R. Bairdia sp. 6, external view of a left valve, sample CM31C (MNHN.F.F63195). S-T. Bairdia sp. 7. S. Right lateral view of a carapace, sample CM31B (MNHN.F.F63196). T. Same specimen, dorsal view. U. Bairdia sp. 8, right lateral view of a carapace, sample CM31B (MNHN.F.F63197). Scale bars: $100 \mu \mathrm{m}$. 


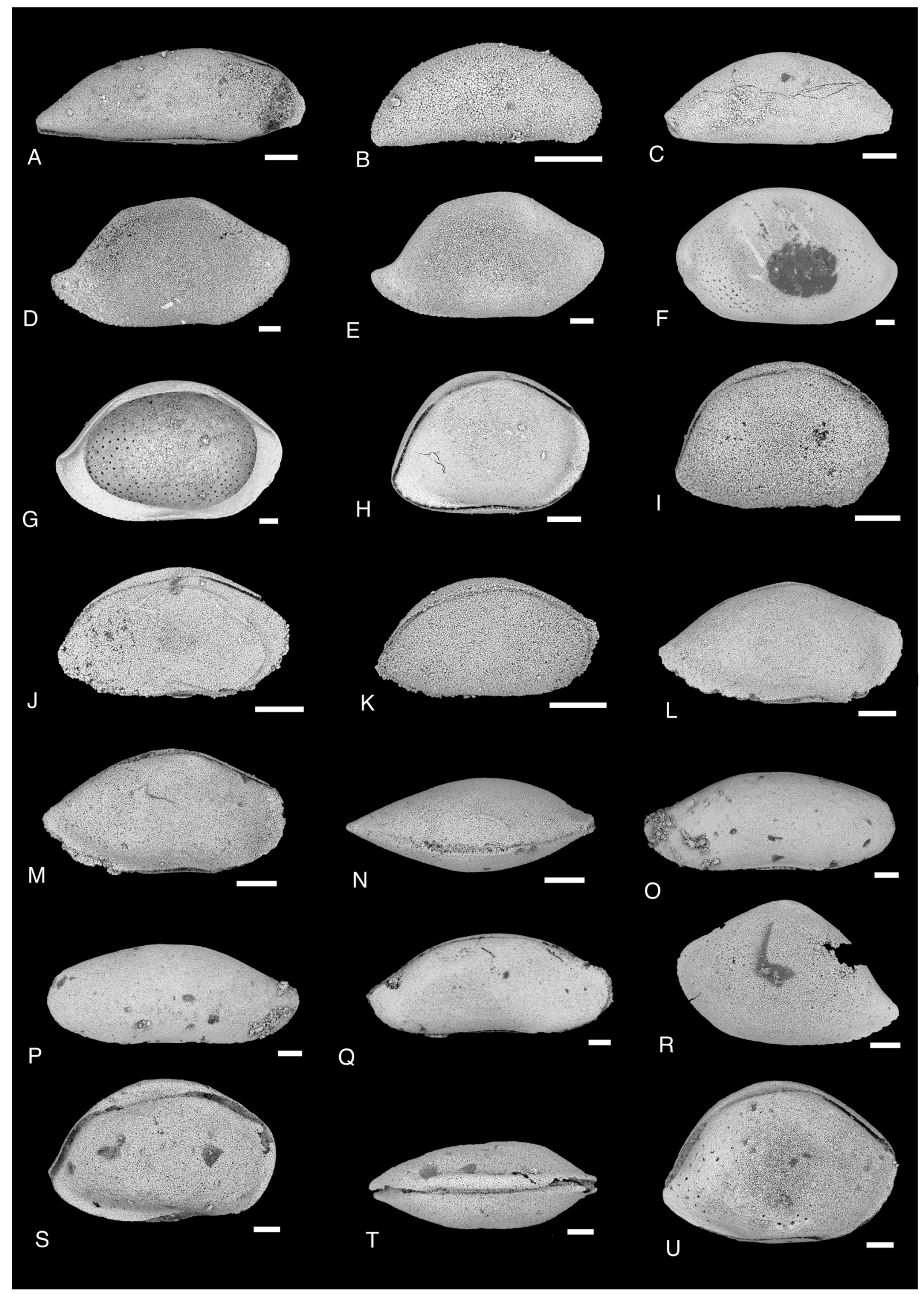


Dimensions (this paper)

RV: $\mathrm{L}=372-1138 \mu \mathrm{m} ; \mathrm{H}=200-603 \mu \mathrm{m} ; \mathrm{H} / \mathrm{L}=0.53-0.56$.

LV: $\mathrm{L}=372-1212 \mu \mathrm{m} ; \mathrm{H}=205-768 \mu \mathrm{m} ; \mathrm{H} / \mathrm{L}=0.55-0.63$.

\section{Occurrence}

Kössen Formation, Northern Calcareous Alps, Tyrol, Austria, Rhaetian, Upper Triassic (Mette \& MohtatAghai 1999); Romanian Continental Shelf, Black Sea, Rhaetian, Upper Triassic (this paper).

\section{Remarks}

Bairdia sp. 7 in Mette \& Mohtat-Aghai 1999 was first recorded from the Kössen Formation outcropping in the Northern Calcareous Alps (Mette \& Mohtat-Aghai 1999). This species is higher and slightly shorter than B. cassiana (Reuss, 1869), which is largely documented from the Early Anisian-Late Carnian interval of Europe (Reuss 1869; Gümbel 1869; Styk 1958; Urlichs 1972; Kristan-Tollmann 1978; Kristan-Tollmann et al. 1991b; Monostori 1995; Crasquin-Soleau \& Grădinaru 1996; Monostori \& Tóth 2013, 2014; Mette et al. 2015; Crasquin et al. 2018; Forel et al. 2020). It also shares morphological proximity with B. jiangyouensis Xie in Wei et al., 1983 from the Carnian-Norian interval of Sichuan Province, South China (Wei et al. 1983; Forel et al. 2019b), from which it differs by a larger and slightly less caudate posterior end and an anterior maximum of convexity located lower. Bairdia jiangyouensis is also characterized by having LV overlapping RV all around: the nature of the overlap cannot be completely characterized for the present species as only juvenile carapaces have been found, with an interrupted overlap along AVB and AB. Bairdia sp. 7 in Mette \& Mohtat-Aghai 1999 also differs from Bairdia sp. A in Bolz 1971 from the Zlambach Formation, Norian-Rhaetian, of the Northern Calcareous Alps (Bolz 1971a: pl. 7, figs 82-83) in having a tripartite dorsal margin on RV, while it is uniformly convex in Bairdia sp. A. It also differs from Bairdia sp. B in Bolz 1971 (Bolz 1971a: pl. 7, figs $82-83$ ) by having its DB inclined posteriorly, PB larger and less caudate and AVB less convex and anteriorly projected. It is also close to Bairdia sp. in Kristan-Tollmann 1979 from the Rhaetian of Iran (Kristan-Tollmann et al. 1979), but the RV of the Iranian species has a shorter posterior end, a pronounced concavity at the ADB and a slight concavity at the base of the AVB. Crasquin et al. (2018) recently considered that Bairdia sp. 3 from the Carnian, Late Triassic, of Sicily (Crasquin et al. 2018: fig. 6u) might be conspecific with Bairdia sp. 7 in Mette \& Mohtat-Aghai 1999. However, the specimen shown in Crasquin et al. (2018) has a longer and more caudate posterior border, with AVB and PVB slightly compressed laterally in their median extremity. For this reason, we do not consider these taxa to be conspecific. Bairdia sp. 7 in Mette \& Mohtat-Aghai 1999 is undeniably new to science, but it is kept in open nomenclature until complete carapaces are discovered to fully describe the overlap of the LV over RV. The description of the ontogeny of the species listed above will allow the clarification of their possible conspecificities, but until now most of them are only know from a few specimens.

Genus Bairdiacypris Bradfield, 1935

\section{Type species}

Bairdiacypris deloi Bradfield, 1935, by original designation.

Bairdiacypris multidentata Bolz, 1971

Fig. 6D-E

Bairdiacypris multidentata Bolz, 1971b: 230-231, pl. 8, figs 98-100.

Bairdiacypris multidentata - Mette et al. 2012: 70. 


\section{Material examined}

ROMANIA - 1 complete carapace; Black Sea, Romanian Continental Shelf, borehole 817LV, sample CM31A; Rhaetian, Upper Triassic; MNHN.F.F63199 • 1 complete carapace; same locality as for preceding but sample CM31B; Rhaetian, Upper Triassic; MNHN.F.F63200 • 1 broken carapace; same collection data as for preceding; Rhaetian, Upper Triassic; MNHN.F.F63343.

\section{Dimensions}

See Fig. 3A.

\section{Occurrence}

Northern Calcareous Alps, Tyrol, Austria, Norian-Rhaetian, Upper Triassic (Bolz 1971b; Mette et al. 2012); Romanian Continental Shelf, Black Sea, Rhaetian, Upper Triassic (this paper).

\section{Remarks}

Bairdiacypris cf. multidentata Bolz, 1971 has been reported from the Eiberg Member, Kössen Formation, outcropping at the Eiberg section in the Northern Calcareous Alps (Mette et al. 2012: 70), but no illustration and no discussion were provided to further discuss this attribution. Bolz (1971b) provided dimensions of complete carapaces, LV and RV: owing to the overlap of LV over RV in $B$. multidentata, the dimensions of carapaces are here treated as those of LV and all dimensions are plotted in Fig. 3A. Bolz (1971b) illustrated three specimens and stated that the material was not sufficient for an investigation of the ontogeny (Bolz 1971b: 231). Although the lack of illustrated specimens doesn't allow a discussion of the morphological changes in B. multidentata through its development, the large dispersion of the $\mathrm{H} / \mathrm{L}$ scatter plot of all specimens points to a mixture of ontogenetic stages, at least corresponding to five ontogenetic stages (A-4 to adult). The holotype appears to be an immature stage. The only measurable carapace found during the present analysis (Fig. 6E) is the smallest known carapace of B. multidentata and corresponds to a very young juvenile in the A-4 stage (Fig. 3A).

Bairdiacypris argonautaii Forel sp. nov. urn:lsid:zoobank.org:act:4AF32BE0-8E7A-4ABD-BCC8-42D2F99F451F

Fig. $6 \mathrm{~F}-\mathrm{O}$

Bairdiacypris? aff. Bairdiacypris sp. A Bolz - Mette \& Mohtat-Aghai 1999: pl. 3, fig. 7.

\section{Diagnosis}

A new species ovoid in shape, with overlap interrupted at AVB and PVB, RV preplete and LV amplete to postplete.

\section{Etymology}

From the ancient Greek Apyovaṽ $\alpha 1$, Argonautai, referring to the mythological heroes, the argonauts, who travelled the Black Sea searching for the golden fleece.

\section{Material examined}

\section{Holotype}

AUSTRIA • 1 RV; Northern Calcareous Alps, Tyrol; Kössen Formation, Rhaetian, Upper Triassic (Mette \& Mohtat-Aghai 1999: pl. 3, fig. 7); University of Innsbruck, Austria. 
Paratypes

ROMANIA • 1 RV; Black Sea, Romanian Continental Shelf, borehole 817LV, sample CM31A; Rhaetian, Upper Triassic; MNHN.F.F63201 • 1 complete carapace; same collection data as for preceding; Rhaetian, Upper Triassic; MNHN.F.F63202.

\section{Other material}

ROMANIA 1 complete carapace; Black Sea, Romanian Continental Shelf, borehole 817LV, sample CM31A; Rhaetian, Upper Triassic; MNHN.F.F63203 • 1 complete carapace; same collection data as for preceding; Rhaetian, Upper Triassic; MNHN.F.F63204 1 complete carapace; same collection data as for preceding; Rhaetian, Upper Triassic; MNHN.F.F63206 • 1 complete carapace; same collection data as for preceding; Rhaetian, Upper Triassic; MNHN.F.F63207 • 1 complete carapace; same locality as for preceding but sample CM31B; Rhaetian, Upper Triassic; MNHN.F.F63205 • 1 complete carapace; same collection data as for preceding; Rhaetian, Upper Triassic; MNHN.F.F63208.

\section{Dimensions}

See Fig. 3B.

\section{Description}

CARAPACE. Very large, massive, ovoid in lateral view with $\mathrm{L}_{\text {max }}$ below mid-H at both valves; LV larger than RV, overlapping it all along dorsal margin with maximum at $\mathrm{DB}$, and along VB, overlap interrupted along AVB and PVB; biconvex in dorsal view with $\mathrm{W}_{\text {max }}$ behind $\mathrm{L}_{\text {max }}$, overlapping area seemingly flat; surface smooth.

RV. Subrectangular with $\mathrm{H}_{\text {max }}$ at antero-dorsal angulation; dorsal margin tripartite with dulled angulations; PDB straight to slightly convex in young instars, short $\left(12-21 \%\right.$ of $\left.\mathrm{L}_{\max }\right)$ and steeply sloping to $\mathrm{PB}$ $\left(60-70^{\circ}\right)$; DB straight, moderately sloping to postero-dorsal angulation $\left(10-20^{\circ}\right)$ with length increasing through ontogeny; ADB straight, long, with relatively constant length through ontogeny $(37-45 \%$ of L), sloping toward $\mathrm{AB}$ with an angle ranging from $20^{\circ}$ to $40^{\circ}$; $\mathrm{AB}$ large, relatively bairdiid in shape, with maximum of curvature at or slightly below mid-H; ventral margin long and sinuous; AVB steeply raised

Fig. 6 (opposite page). SEM micrographs of ostracods from borehole 817 Lebăda Vest, drill core CM31, western portion of Black Sea shelf, Rhaetian, Late Triassic. All specimens are housed in the collections of the Muséum national d'histoire naturelle, Paris, France (MNHN). A. Bairdia sp. 8, same specimen as in Fig. 5U, dorsal view. B-C. Bairdia sp. 9. B. Right lateral view of a carapace, sample CM31C (MNHN.F.F63198). C. Same specimen, dorsal view. D-E. Bairdiacypris multidentata Bolz, 1971. D. Right lateral view of a carapace, sample CM31A (MNHN.F.F63199). E. Right lateral view of a carapace, sample CM31B (MNHN.F.F63200). F-O. Bairdiacypris argonautaii Forel sp. nov. F. Paratype 2, right lateral view of a carapace, sample CM31 A(MNHN.F.F63201). G. Paratype 1, external view of a right valve, sample CM31B (MNHN.F.F63202). H. Right lateral view of a carapace, sample CM31A (MNHN.F.F63203). I. Right lateral view of a carapace, sample CM31A (MNHN.F.F63204). J. Right lateral view of a carapace, sample CM31B (MNHN.F.F63205). K. Same specimen, dorsal view. L. Right lateral view of a carapace, sample CM31A (MNHN.F.F63206). M. Right lateral view of a carapace, sample CM31A (MNHN.F.F63207). N. Same specimen, dorsal view. O. Right lateral view of a carapace, sample CM31A (MNHN.F.F63208). P. Bairdiacypris sp. in Forel et al. 2018, external view of a right valve, sample CM31A (MNHN.F.F63209). Q. Bairdiacypris sp. 1, external view of a right valve, sample CM31A (MNHN.F.F63210). R. Bairdiacypris sp. 2, external view of a right valve, sample CM31C (MNHN.F.F63211). S. Bairdiacypris sp. 3, external view of a right valve, sample CM31B (MNHN.F.F63212). T-U. Bairdiacypris? sp. 4. T. Right lateral view of a carapace, sample CM31B (MNHN.F.F63213). U. Right lateral view of a carapace, sample CM31A (MNHN.F.F63214). Scale bars: $100 \mu \mathrm{m}$. 


\section{FOREL M.-B. \& GRĂDINARU E., Late Triassic ostracods of North Dobrogean Orogen}

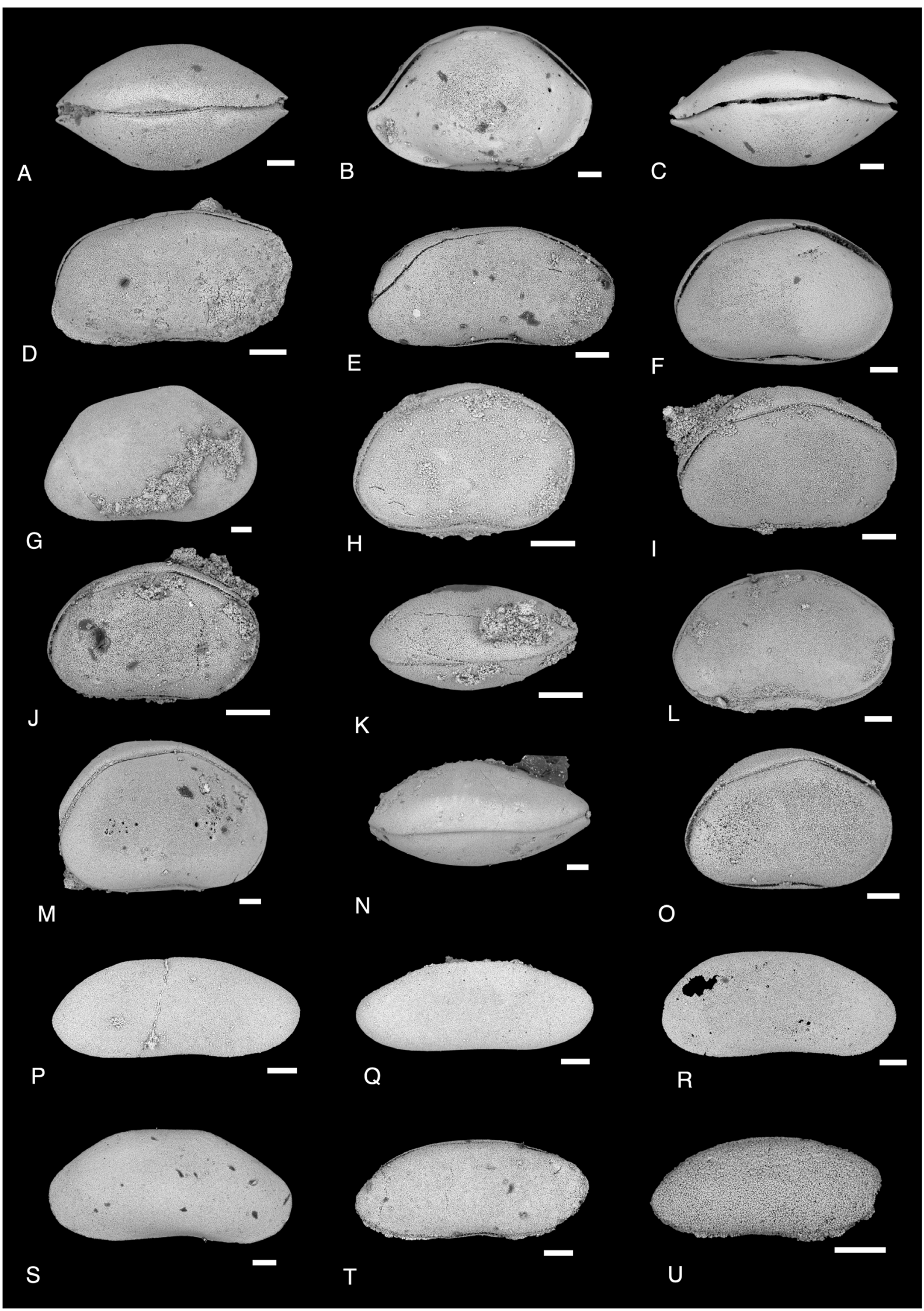


to $\mathrm{AB}$ and largely convex to close to vertical in young instars; VB with tenuous oral concavity mid-L; PVB short, convex, only slightly raised to $\mathrm{PB}$; $\mathrm{PB}$ at lower $1 / 4$ of $_{\text {max }}$, relatively narrow, gently rounded to only slightly bairdiid in shape.

LV. Ovoid with $\mathrm{H}_{\max }$ behind mid-H in large forms, at antero-dorsal angulation in younger instars; dorsal margin gently rounded with dulled angulations in young instars that are unrecognizable in larger instars and adults; ventral margin long and straight to gently convex.

\section{Occurrence}

Kössen Formation, Northern Calcareous Alps, Tyrol, Austria, Rhaetian, Upper Triassic (Mette \& MohtatAghai 1999); Romanian Continental Shelf, Black Sea, Rhaetian, Upper Triassic (this paper).

\section{Remarks}

Bairdiacypris argonautaii sp. nov. is higher and shorter than "Bairdia" raetica Bolz, 1971 from the Rhaetian interval, Late Triassic, of Tyrol (Bolz 1971b); it also differs by the antero-ventral and postero-ventral interruption of the overlap, dorsal margin tripartite with pronounced antero-dorsal and postero-dorsal angulations and anterior margin larger. Bairdiacypris argonautaii sp. nov. is also close to Bairdiacypris sp. in Kristan-Tollmann et al. 1979 from the Rhaetian, Late Triassic, of Iran (KristanTollmann et al. 1979) but the only illustrated Iranian specimen shows a continuous overlap along AVB and PVB and a posterior maximum of convexity located higher resulting in subsymmetric anterior and posterior borders. Bairdiacypris argonautaii sp. nov. is also morphologically close to Bairdia cf. peneovoidea Bolz, 1971 from the Rhaetian, Late Triassic, of Iran (Kristan-Tollmann et al. 1979) but has a more rounded AVB and a larger PB. The dimensions of all specimens attributed to $B$. argonautaii sp. nov. are plotted in Fig. 3B. The largest specimen known to date is a right valve from the Rhaetian of Tyrol (Mette \& Mohtat-Aghai 1999). All specimens found in the present investigation are distributed across at least six successive ontogenetic stages, all smaller than the specimen from Mette \& Mohtat-Aghai (1999). The ontogenetic development of B. argonautaii sp. nov. is mainly marked by an enlargement of the posterior end of the carapace.

Bairdiacypris sp. in Forel et al. 2018

Fig. 6P

Bairdiacypris sp. - Forel et al. 2018: fig. 4/16.

\section{Material examined}

ROMANIA • 1 RV; Black Sea, Romanian Continental Shelf, borehole 817LV, sample CM31A; Rhaetian, Upper Triassic; MNHN.F.F63209.

\section{Dimensions}

RV in Forel et al. (2018): $\mathrm{L}=774 \mu \mathrm{m} ; \mathrm{H}=320 \mu \mathrm{m} ; \mathrm{H} / \mathrm{L}=0.41$.

$\mathrm{RV}$ in this paper: $\mathrm{L}=766 \mu \mathrm{m} ; \mathrm{H}=331 \mu \mathrm{m} ; \mathrm{H} / \mathrm{L}=0.43$.

\section{Occurrence}

Killik Formation, Tavusçayiri Block, Sorgun Ophiolitic Mélange, southern Turkey, Huğlu Tuffite, Spongotortilispinus moixi radiolarian Zone, lower Tuvalian, Upper Carnian, Upper Triassic (Forel et al. 2018); Romanian Continental Shelf, Black Sea, Rhaetian, Upper Triassic (this paper).

\section{Remarks}

Bairdiacypris sp. in Forel et al. 2018 is related to Bairdiacypris anisica Kozur, 1971 from the Anisian, Middle Triassic, of Hungary (Kozur 1971c). However, only one valve has been found here; since bairdiids are very homoplastic ostracods, it is most reasonable to avoid artificially extending the 
stratigraphic range of Bairdiacypris anisica Kozur, 1971, from the Middle Triassic to the end of the Rhaetian, until more material is available to clarify this possibility. Bairdiacypris sp. in Forel et al. 2018 is also morphologically close to Bairdiacypris sp. in Forel et al. 2019 from the Carnian, Late Triassic, of the Kilek section in Turkey (Forel et al.2019a), but the anterior border is more raised in the present material. In the present analysis, Bairdiacypris sp. in Forel et al. 2018 is primarily related to Bairdiacypris sp. 1, from which it differs mainly by the morphology of the posterior extremity and the position of the oral concavity in front of $\mathrm{H}_{\text {max }}$, while it is at mid-L in Bairdiacypris sp. 1.

\section{Bairdiacypris sp. 1}

Fig. 6Q

\section{Material examined}

ROMANIA • 1 RV; Black Sea, Romanian Continental Shelf, borehole 817LV, sample CM31A; Rhaetian, Upper Triassic; MNHN.F.F63210.

\section{Dimensions}

$\mathrm{L}=821 \mu \mathrm{m} ; \mathrm{H}=311 \mu \mathrm{m} ; \mathrm{H} / \mathrm{L}=0.38$.

\section{Occurrence}

Romanian Continental Shelf, Black Sea, Rhaetian, Upper Triassic (this paper).

\section{Remarks}

Bairdiacypris sp. 1 differs from Bairdiacypris sp. in Forel et al. 2018 in being more elongate in lateral view with a more elongate posterior end, PB located higher and PDB concave, while it is uniformly convex in Bairdiacypris sp. in Forel et al. 2018. Bairdiacypris sp. 1 is also close to Fabalicypris triassica Bolz, 1971 from the Norian-Rhaetian of the Northern Calcareous Alps (Bolz 1971b), but it differs by its higher posterior end and straight DB. In spite of the lack of a complete carapace to observe the nature of its ventral overlap, Bairdiacypris sp. 1 has a clear tripartite dorsal margin, which precludes the attribution to Fabalicypris.

\section{Bairdiacypris sp. 3}

Fig. 6S

\section{Material examined}

ROMANIA • 1 RV; Black Sea, Romanian Continental Shelf, borehole 817LV, sample CM31B; Rhaetian, Upper Triassic; MNHN.F.F63212 • 1 complete carapace; same collection data as for preceding; Rhaetian, Upper Triassic; MNHN.F.F63344.

\section{Dimensions}

$\mathrm{L}=1060 \mu \mathrm{m} ; \mathrm{H}=481 \mu \mathrm{m} ; \mathrm{H} / \mathrm{L}=0.45$.

\section{Occurrence}

Romanian Continental Shelf, Black Sea, Rhaetian, Upper Triassic (this paper).

\section{Remarks}

Bairdiacypris sp. 3 is close to Fabalicypris n. sp. in Kristan-Tollmann et al. 1980 from the Rhaetian of Iran (Kristan-Tollmann et al. 1980), but the present species has a tripartite dorsal margin at RV 
with longer DB and lacks the Fabalicypris offset of the ventral overlap. Bairdiacypris sp. 3 is also close to Bairdiacypris? sp. 2 in Lord \& Lambourne 1991 from the Pliensbachian, Early Jurassic, of Turkey (Lord \& Lambourne 1991), from which it differs in being larger with a less elongate posterior end. Bairdiacypris sp. 3 shares a strong similarity with Bairdiacypris sp. B in Bolz 1971 from the Rhaetian interval of the Northern Calcareous Alps (Bolz 1971b), which is only shown as inner views. However, Bairdiacypris sp. 3 has a shorter DB and a larger PB with maximum of convexity located higher. Bairdiacypris sp. 3 is also larger than Bairdiacypris sp. B in Bolz $1971(\mathrm{~L}=690-950 \mu \mathrm{m}$; $\mathrm{H}=320-500 \mu \mathrm{m} ; \mathrm{H} / \mathrm{L}=0.44-0.55$ ), with a similar $\mathrm{H} / \mathrm{L}$ ratio; this characteristic could relate to ontogeny. It is nevertheless worth noting that the $\mathrm{H} / \mathrm{L}$ ratio of Bairdiacypris sp. B in Bolz 1971 mainly ranges from 0.44 to 0.48 (Bolz 1971b: 231). The dimensions provided for the specimen illustrated in Bolz (1971b: pl 8, fig. 104) are $\mathrm{L}=900 \mu \mathrm{m}$ and $\mathrm{H}=500 \mu \mathrm{m}$, leading to an $\mathrm{H} / \mathrm{L}$ ratio of 0.55 .

\section{Bairdiacypris? sp. 4}

Fig. 6T-U

\section{Material examined}

ROMANIA 1 complete carapace; Black Sea, Romanian Continental Shelf, borehole 817LV, sample CM31B; Rhaetian, Upper Triassic; MNHN.F.F63213 - 1 complete carapace; same locality as for preceding but sample CM31A; Rhaetian, Upper Triassic; MNHN.F.F63214 - 5 complete carapaces; same locality as for preceding but samples CM31A, CM31B and CM31C; Rhaetian, Upper Triassic; MNHN.F.F63345.

\section{Dimensions}

RV: $\mathrm{L}=327-809 \mu \mathrm{m} ; \mathrm{H}=157-326 \mu \mathrm{m} ; \mathrm{H} / \mathrm{L}=0.38-0.48$.

$\mathrm{LV}: \mathrm{L}=327-809 \mu \mathrm{m} ; \mathrm{H}=167-348 \mu \mathrm{m} ; \mathrm{H} / \mathrm{L}=0.41-0.51$.

\section{Occurrence}

Romanian Continental Shelf, Black Sea, Rhaetian, Upper Triassic (this paper).

\section{Remarks}

The absence of an antero-ventral offset of the overlap leads to the generic attribution to Bairdiacypris rather than Fabalicypris. However, in the absence of angulations at the dorsal margin, this identification is still tentative. Bairdiacypris? sp. 4 is closely related to Fabalicypris? praelonga Donze, 1966 from the Plicatulus Horizon, Hettangian, Early Jurassic, of Le Sartre, Ardèche, France (Donze 1966). However, Bairdiacypris? sp. 4 differs by having a more bairdiid $\mathrm{AB}$ with a maximum of curvature located higher and the AVB more raised dorsally. It is worth noting that the doubt in the generic attribution of Fabalicypris? praelonga is related to Donze's inability to observe the inner structures (Donze 1966).

\section{Genus Carinobairdia Kollmann, 1963}

\section{Type species}

Carinobairdia triassica triassica Kollmann, 1963 by original designation.

\section{Remarks}

Carinobairdia triassica triassica Kollmann, 1963 and C. alpina Kollmann, 1963 emend. KristanTollmann 1970 are both typical for the Rhaetian, Late Triassic, of the western Tethys and Iran as shown by the occurrences lists. Until recently, Carinobairdia was restricted to the Rhaetian of the western area of the Tethys, but the discovery of a Carnian species traced the roots of this genus to the eastern Tethys (Forel et al. 2019b). 
Carinobairdia triassica triassica Kollmann, 1963

Fig. 7A-B

Carinobairdia triassica Kollmann, 1963: 191-192, pl. 3, figs 5-9, pl. 11, fig. 1.

Carinobairdia triassica - Bolz 1969: 413, pl. 1, figs 1-6, pls 2-5. - Kristan-Tollmann 1969: 86, pl. 4. — Bolz 1971a: pl. 2, fig. 5. — Hillebrandt et al. 2007: fig. 14. — Zorn 2010: 273, pl. 5, figs 15-16, pl. 8, fig. 5 .

Carinobairdia triassica triassica - Kristan-Tollmann 1970: 297, pl. 5, figs 1-2, pl. 35, fig. 6; 1988: fig. 6/4. - Kristan-Tollmann et al. 1980: 4-5, pl. 7, figs 1-6.

Lobobairdia triassica - Urlichs 1972: 229, pl. 1, fig. 3. — Mette \& Mohtat-Aghai 1999: pl. 5, figs 6-7. - Hillebrandt et al. 2013: 176, pl. 5, figs 15-16, pl. 8, fig. 5.

\section{Material examined}

ROMANIA • 1 RV; Black Sea, Romanian Continental Shelf, borehole 817LV, sample CM31B; Rhaetian, Upper Triassic; MNHN.F.F63215 • 1 RV; same locality as for preceding but sample CM31C; Rhaetian, Upper Triassic; MNHN.F.F63216 • 1 RV, 2 LV; same locality as for preceding but samples CM31B and CM31C; Rhaetian, Upper Triassic; MNHN.F.F63346.

\section{Dimensions}

RV (sample CM31C, Fig. 7B): $\mathrm{L}=703 \mu \mathrm{m} ; \mathrm{H}=390 \mu \mathrm{m} ; \mathrm{H} / \mathrm{L}=0.55$.

RV (sample CM31B, Fig. 7A): $\mathrm{L}=576 \mu \mathrm{m} ; \mathrm{H}=334 \mu \mathrm{m} ; \mathrm{H} / \mathrm{L}=0.58$.

\section{Occurrence}

Zlambach Formation, Plackleswiese, W Plackles, Hohe Wand, NW Wiener Neustadt, Lower Austria, Austria, Rhaetian, Upper Triassic (Kollmann 1963; Zorn 2010); Zlambach Formation, Höllgraben, Krautgartenalm, Grünbachgraben, Austria, Rhaetian, Upper Triassic (Bolz 1969, 1971a; KristanTollmann 1969, 1970); Kössen Formation, Weissloferbach, Kössen, Austria, Rhaetian, Upper Triassic (Urlichs 1972); Kössen Formation, Northern Calcareous Alps, Tyrol, Austria, Rhaetian, Upper Triassic (Mette \& Mohtat-Aghai 1999); Kössen Formation, Eiberg Member, Kuhjoch, Karwendel Mountains, Northern Calcareous Alps, Tyrol, Austria, marshi Zone, Rhaetian, Upper Triassic (Hillebrandt et al. 2007, 2013); Kössen, Austria, Rhaetian, Upper Triassic (Urlichs 1972); Nayband Formation, WaliAbad, Iran, Rhaetian, Upper Triassic (Kristan-Tollmann et al. 1980; Kristan-Tollmann 1988); Romanian Continental Shelf, Black Sea, Rhaetian, Upper Triassic (this paper).

\section{Remarks}

Opinions on the validity of the genus Carinobairdia and the species C. triassica have varied through time and among authors. The taxonomic scheme established by Kollmann (1963) was accepted and followed by Kristan-Tollmann $(1969,1970,1988)$ and Kristan-Tollmann et al. $(1979,1980)$. Kristan-Tollmann (1970) additionally created the subspecies C. triassica interrupta from the Rhaetian of Austria, which led to the re-qualification of C. triassica as C. triassica triassica. The opinion of Bolz (1971a, 1971b) differed in drastic ways: he re-attributed C. triassica and C. umbonata to the genus Lobobairdia and furthermore considered Carinobairdia as a synonym of both Lobobairdia and Triebelina (Nodobairdia). Conversely, Urlichs (1972) first followed the re-attributions of Bolz (1971a, 1971b), later came back to the original scheme by using the genus Carinobairdia (in Hillebrandt et al. 2007) and again used the Bolz (1971a, 1971b) scheme (in Hillebrandt et al. 2013). It is out of the scope of the present paper to discuss these schemes in detail: the above summary clearly shows the volatility of the positions adopted through time and the non-robustness of characters and discussions on their significance. The status of the generic classification of Bairdiidae is in need of a detailed and thorough analysis with phylogenetic tools and cladistics. Such an analysis is currently in progress. However, to stop complicating the taxonomic 
situation of sculptured Bairdiidae, we choose to go on using the original scheme until an analysis of the phylogeny of these ostracods and of the significance of ornamentation if performed.

Bolz (1969) measured and discussed more than 200 specimens of Carinobairdia triassica triassica Kollmann, 1963. According to the $\mathrm{H}$ and $\mathrm{L}$ ranges provided in that paper, the RV found in the present investigation are juveniles: A-2 stage for the RV obtained from sample CM31C (Fig. 7B), A-3 from the valve obtained from sample CM31B (Fig. 7A).

Carinobairdia alpina Kollmann, 1963 emend. Kristan-Tollmann 1970

Fig. 7C-F

Carinobairdia alpina Kollmann, 1963: 194-195, pl. 3, figs 3-4, pl. 11, figs 9-12.

Carinobairdia alta Kollmann, 1963: 195, pl. 11, figs 2-4.

Carinobairdia tenuicarinata Kollmann, 1963: 196, pl. 11, figs 5-8.

Carinobairdia alpina - Kristan-Tollmann 1964: 71, pl. 3, fig. 8; 1970: 297, pl. 5, figs 5-7; 1988: fig. 6/5. — Bolz 1971a: pl. 2, fig. 6. — Kristan-Tollmann et al. 1979: 150, pl. 6, fig. 5; 1980: 183-184, pl. 7, figs 7-10.

Triebelina (Nodobairdia) alpina - Bolz 1971b: 218-221, pl. 16, figs 233-243. — Urlichs 1972: 676, pl. 1, fig. 2.

Nodobyirdia alpina [sic] - Mette \& Mohtat-Aghai 1999: pl. 5, fig. 5.

Nodobairdia alpina - Urlichs \& Krystyn 2016: 20. - Hillebrandt et al. 2013: 175.

\section{Material examined}

ROMANIA • 1 RV; Black Sea, Romanian Continental Shelf, borehole 817LV, sample CM31C; Rhaetian, Upper Triassic; MNHN.F.F63217 - 1 broken LV; same locality as for preceding but sample CM31B; Rhaetian, Upper Triassic; MNHN.F.F63218 - 1 LV; same collection data as for preceding; Rhaetian, Upper Triassic; MNHN.F.F63219.

\section{Dimensions}

See Fig. 3C.

Fig. 7 (opposite page). SEM micrographs of ostracods from borehole 817 Lebăda Vest, drill core CM31, western portion of Black Sea shelf, Rhaetian, Late Triassic. All specimens are housed in the collections of the Muséum national d'histoire naturelle, Paris, France (MNHN). A-B. Carinobairdia triassica triassica Kollmann, 1963. A. External view of a right valve, sample CM31B (MNHN.F.F63215). B. External view of a right valve, sample CM31C (MNHN.F.F63216). C-F. Carinobairdia alpina Kollmann, 1963 emend. Kristan-Tollmann 1970. C. External view of a right valve, sample CM31C (MNHN.F.F63217). D. External view of a broken left valve, sample CM31B (MNHN.F.F63218). E. External view of a left valve, sample CM31B (MNHN.F.F63219). F. Same specimen, inner view. G-S. Ceratobairdia? akhilleusi Forel sp. nov. G. External view of a left valve, sample CM31C (MNHN.F.F63220). H. Paratype 2, right lateral view of a carapace, sample CM31A (MNHN.F.F63221). I. Same specimen, dorsal view. J. Paratype 1, right lateral view of a carapace, sample CM31C (MNHN.F.F63222). K. Same specimen, dorsal view. L. External view of a right valve, sample CM31A (MNHN.F.F63223). M. Holotype, external view of a left valve, sample CM31B (MNHN.F.F63224). N. Same specimen, inner view. O. Detail of the muscle scar field area (topography mode). P. Detail of the posterior end of hingement. Q. Detail of the anterior end of hingement. R. External view of a left valve, sample CM31A (MNHN.F.F63225). S. Same specimen, inner view. T. Ceratobairdia sp., external view of a broken left valve, sample CM31A (MNHN.F.F63226). U. Fabalicypris cf. triassica Bolz, 1971, right lateral view of a carapace, sample CM31A (MNHN.F.F63227). Scale bars: $100 \mu \mathrm{m}$. 


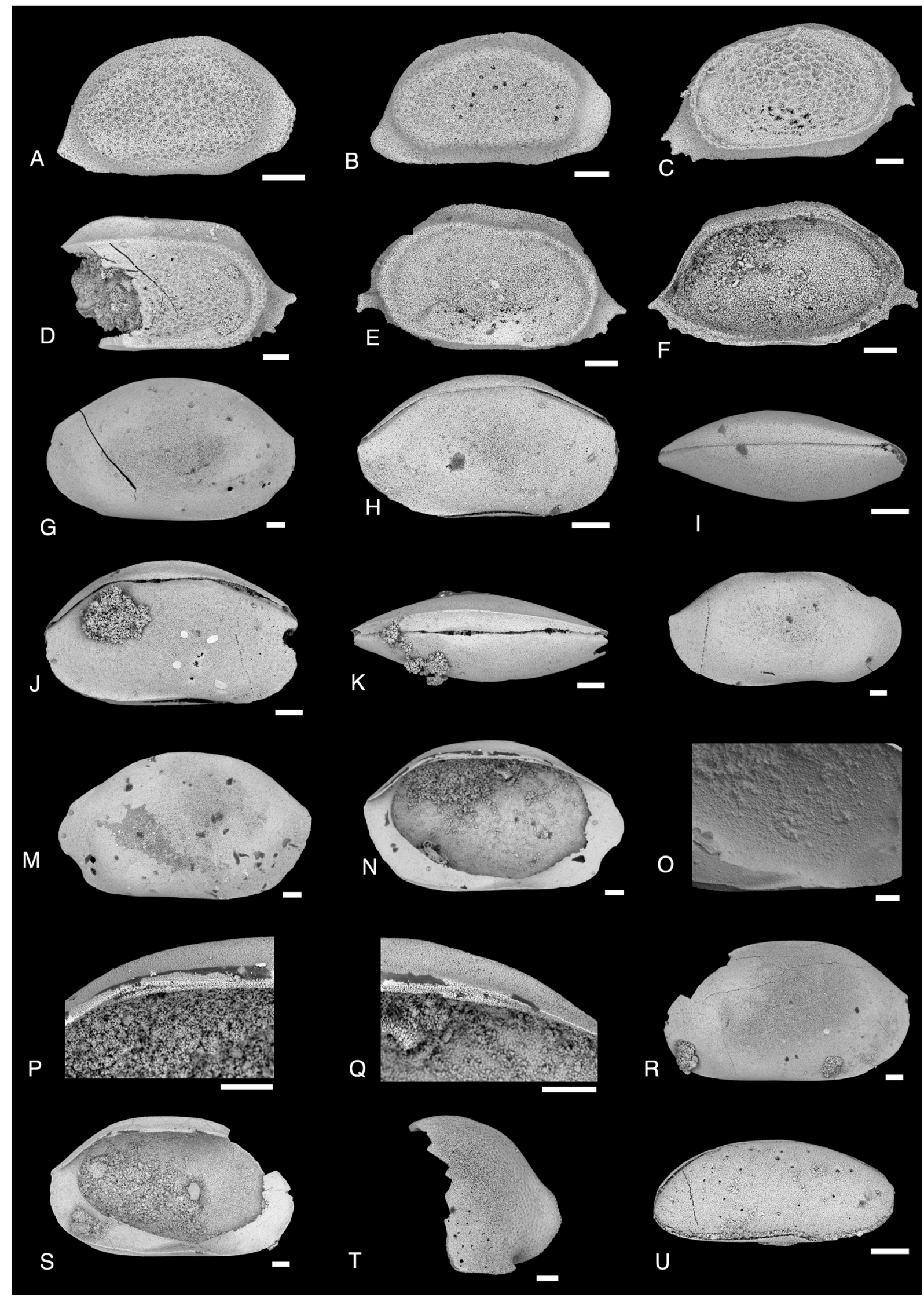




\section{Occurrence}

Zlambach Formation, Backhaus Member, Elisabeth Member, Josef Member, Grünbachgraben and Mergel, Dolomitenhütte and Plackles, Austria, Rhaetian, Upper Triassic (Kollmann 1963); Kössen Formation, Northern Calcareous Alps, Tyrol, Austria, Rhaetian, Upper Triassic (Kristan-Tollmann 1964; Mette \& Mohtat-Aghai 1999); Zlambach Formation, Höllgraben, Krautgartenalm, Grünbachgraben, Austria, Rhaetian, Upper Triassic (Kristan-Tollmann 1969, 1970); Zlambach Formation, Fischerwiese, Aussee, Salzkammergut, Austria, Rhaetian, Upper Triassic (Kristan-Tollman, 1970); Zlambach beds, Grünbachgraben, Northern Calcareous Alps, Rhaetian, Upper Triassic (Bolz 1971a, 1971b); Kössen Formation, Weissloferbach, Kössen, Austria, Rhaetian, Upper Triassic (Urlichs 1972); Kössen Formation, Eiberg section, Northern Calcareous Alps, Rhaetian, Upper Triassic (Mette et al. 2012; Hillebrandt et al. 2013); Steinbergkogel, Austria, uppermost Hallstatt Limestone Formation and lowermost Zlambach Formation, Paracochloceras suessi Zone, Vandaites stuerzenbaumi Zone, Choristoceras marshi Zone, Early Rhaetian, Upper Triassic (Urlichs \& Krystyn 2016); Waliabad, Abadeh, Iran, Rhaetian, Upper Triassic (Kristan-Tollmann et al. 1979); Nayband Formation, Wali-Abad, Iran, Rhaetian, Upper Triassic (Kristan-Tollmann et al. 1980; Kristan-Tollmann 1988); Romanian Continental Shelf, Black Sea, Rhaetian, Upper Triassic (this paper).

\section{Remarks}

This species was alternatively attributed to Triebelina (Nodobairdia) by Bolz (1971b) and to the newly erected Bolzibairdia by Kozur (1985). As discussed for Carinobairdia triassica triassica, we follow the original generic scheme introduced by Kollmann (1960, 1963). However, we follow Bolz (1971a, 1971b) in considering that C. alta Kollmann, 1963 (erected on LV only) and C. tenuicarinata Kollmann, 1963 (considered as juveniles) are synonyms of C. alpina Kollmann, 1963. Carinobairdia alpina is typical for the Rhaetian, Late Triassic, of western Tethys and Iran as shown by the occurrences list.

The height and length of all specimens of Carinobairdia alpina are plotted in Fig. 3C, which document their distribution in five ontogenetic stages from A-4 to adult. The only carapace known for this species, from the Rhaetian of Iran (Kristan-Tollmann et al. 1980), documents an already important overlap of LV on RV in the A-2. The smallest known specimen is an RV obtained from sample CM31C of the present paper $(\mathrm{L}=535 \mu \mathrm{m} ; \mathrm{H}=292 \mu \mathrm{m} ; \mathrm{H} / \mathrm{L}=0.55)$. The smallest $\mathrm{LV}$ is recorded from the Rhaetian of the Northern Calcareous Alps (Bolz 1971b: $\mathrm{L}=590 \mu \mathrm{m} ; \mathrm{H}=370 \mu \mathrm{m} ; \mathrm{H} / \mathrm{L}=0.63$ ). The Black Sea specimens are small compared to other records and represent immature stages.

\section{Genus Ceratobairdia Sohn, 1954}

\section{Type species}

Ceratobairdia dorsospinosa Sohn, 1954 by original designation.

Ceratobairdia? akhilleusi Forel sp. nov.

urn:1sid:zoobank.org:act:94F7B0AC-8359-4EEF-B620-8334E6DAB902

Fig. $7 \mathrm{G}-\mathrm{S}$

\section{Diagnosis}

A species with rectangular carapace, dorsal overlap of left valve on right valve laterally compressed and postero-ventral border of right valve underlined by a ridge.

\section{Etymology}

From the ancient Greek A $\chi \backslash \lambda \lambda \varepsilon v$ c/Akhilleús referring to the legendary hero Achilles who has been long revered around the Black Sea. 


\section{Material examined}

Holotype

ROMANIA • 1 LV; Black Sea, Romanian Continental Shelf, borehole 817LV, sample CM31B; Rhaetian, Upper Triassic; MNHN.F.F63224.

\section{Paratypes}

ROMANIA 1 complete carapace; same locality as for holotype but sample CM31C; Rhaetian, Upper Triassic; MNHN.F.F63222 - 1 complete carapace; same locality as for holotype but sample CM31A; Rhaetian, Upper Triassic; MNHN.F.F63221.

\section{Other material}

ROMANIA - $1 \mathrm{LV}$; same locality as for holotype but sample CM31C; Rhaetian, Upper Triassic; MNHN.F.F63220 - $1 \mathrm{RV}$; same locality as for holotype but sample CM31A; Rhaetian, Upper Triassic; MNHN.F.F63223 - $1 \mathrm{LV}$; same collection data as for preceding; Rhaetian, Upper Triassic; MNHN.F.F63225 1 carapace, 2 LV, 1 RV; same locality as for holotype but samples CM31A, CM31B and CM31C; Rhaetian, Upper Triassic; MNHN.F.F63347.

\section{Dimensions}

See Fig. 3D.

\section{Description}

CARAPACE. Large, rectangular in lateral view, with $\mathrm{H}_{\max }$ at mid- $\mathrm{L}, \mathrm{L}_{\max }$ above mid- $\mathrm{H}$; position of $\mathrm{W}_{\max }$ variable through ontogeny, posterior to mid-L in LV and anterior to mid-L in RV of immature specimens (Fig. 7I) and around mid-L at both valves in large specimens (Fig. 7K); LV larger that RV, overlapping it along VB and overreaching its dorsal margin with maximum at $\mathrm{DB}$, overreach laterally compressed; surface smooth.

RV. Rectangular in lateral view, with $\mathrm{H}_{\max }$ along DB in large specimens (Fig. 7L) and at antero-dorsal angulation in immature ones (Fig. 7H); dorsal margin divided into subequal ADB, DB and PDB, with concave end of PDB more expressed in mature specimens, straight ADB and DB; dorsal angulations salient and compressed laterally; $\mathrm{AB}$ large, more truncate ventrally in mature specimens, with maximum located above mid-H; PB close to vertical in mature specimens, with maximum of convexity located above mid-H; ventral margin sinuous with oral concavity slightly in front of mid-L.

LV. Subtriangular in lateral view with $\mathrm{H}_{\max }$ at mid-L; dorsal margin evenly convex and laterally compressed, slightly tapered posteriorly in immature specimens (Fig. 7H); outlines of AVB and PVB similar to those of RV, VB straight; in inner view, PVB bordered by a shallow groove; calcified inner lamella from mid-ADB to mid-PDB, largest along AVB and PVB; vestibulum wide along AVB and PVB, nearly non-existent in oral area; selvage moderately expressed; hinge bar long, straight, apparently smooth, with conspicuous anterior and posterior triangular lists; AMS field only partly visible and shows a curved and compact posterior row of four scars and two subcentral scars (Fig. 7O).

\section{Occurrence}

Romanian Continental Shelf, Black Sea, Rhaetian, Upper Triassic (this paper).

\section{Remarks}

Ceratobairdia? akhilleusi sp. nov. is attributed with doubt to Ceratobairdia because the postero-ventral ridge is only visible on RV and not well expressed in all specimens (e.g., Fig. 7L). The laterally compressed overlap of Ceratobairdia? akhilleusi sp. nov. is reminiscent of that in Petasobairdia Chen in Chen \& 
Shi, 1982 described from the Late Permian of South China (Chen \& Shi 1982) and whose taxonomy and stratigraphical as well as geographical distributions are examined in the discussion chapter of this paper. However, the presence of a relatively flat posterior venter with regard to the lateral extension underlined by a ridge leads us to favour attribution to Ceratobairdia. Ceratobairdia? akhilleusi $\mathrm{sp}$. nov. is close to Bairdiacypris? form G in Harloff \& Jäger 1994 from the Sinemurian, Early Jurassic, of the Calcareous Alps (Harloff \& Jäger 1994), from which it differs by having a less upturned PB, a thicker and laterally compressed overlap along the dorsal margin and the presence of a ridge underlining the PVB at RV. The new species is also close to Bairdia michelseni michelseni Herrig, 1979 from the Late Sinemurian, Early Jurassic, of Thüringen (Herrig 1979a), but the German species has a longer and more caudate PB at RV, an anterior maximum of curvature located higher, a pitted surface and lacks the laterally compressed overlap and the ridge along PVB of RV. It can also be compared to Bairdia michelseni arcuatocaudata Monostori, 1996 from the Pliensbachian, Early Jurassic of Hungary (Monostori 1996), but this species also lacks the laterally compressed dorsal overlap and the postero-ventral ridge, which is replaced by a thin lateral compression. Ceratobairdia? akhilleusi sp. nov. can finally be compared with Bairdia cf. michelseni in Honigstein et al. 2014 from the Early Jurassic of Austria (Honigstein et al. 2014), but this species also lacks the distinctive laterally compressed overlap, has a lower PB with a more pronounced PDB concavity and lacks the angulation between DB and ADB on LV. The H/L diagram of measurable specimens (Fig. 3D) shows that the holotype is a sub-mature specimen. The largest specimen of the study, interpreted as an adult, is the second paratype. The ontogeny of Ceratobairdia? akhilleusi sp. nov. is marked by an enlargement of the valves and an accentuation of the PV ridge and dorsal lamella.

Genus Hiatobairdia Kristan-Tollmann, 1970

\section{Type species}

Hiatobairdia subsymmetrica Kristan-Tollmann, 1970 by original designation.

\section{Remarks}

All species of Hiatobairdia occurring in the sediments of borehole $817 \mathrm{LV}$ are closely related to species already described in the literature, but the paucity of specimens forces us to keep them in open nomenclature until further material can be observed.

\section{Hiatobairdia sp. 1}

Fig. 8B

\section{Material examined}

ROMANIA 1 complete carapace; Black Sea, Romanian Continental Shelf, borehole 817LV, sample CM31B; Rhaetian, Upper Triassic; MNHN.F.F63229 • 2 LV; same locality as for preceding but samples CM31B and CM31C; Rhaetian, Upper Triassic; MNHN.F.F63348.

\section{Dimensions}

$\mathrm{RV}: \mathrm{L}=973 \mu \mathrm{m} ; \mathrm{H}=554 \mu \mathrm{m} ; \mathrm{H} / \mathrm{L}=0.57$.

$\mathrm{LV}: \mathrm{L}=710-973 \mu \mathrm{m} ; \mathrm{H}=500-608 \mu \mathrm{m} ; \mathrm{H} / \mathrm{L}=0.62-0.7$.

\section{Occurrence}

Romanian Continental Shelf, Black Sea, Rhaetian, Upper Triassic (this paper).

\section{Remarks}

Hiatobairdia sp. 1 is distinguished from other species known from the literature and from the present assemblages by its relatively poorly expressed lateral compressions along AVB and $\mathrm{PVB}$, large $\mathrm{AB}$ with a maximum of curvature below mid-height and a posterior maximum of curvature located very low. 
Hiatobairdia sp. 2

Fig. 8C-E

\section{Material examined}

ROMANIA 1 complete carapace; Black Sea, Romanian Continental Shelf, borehole 817LV, sample CM31B; Rhaetian, Upper Triassic; MNHN.F.F63230 - 1 LV; same collection data as for preceding; Rhaetian, Upper Triassic; MNHN.F.F63231 - 2 LV; same collection data as for preceding; Rhaetian, Upper Triassic; MNHN.F.F63349.

\section{Dimensions}

RV: $\mathrm{L}=1068 \mu \mathrm{m} ; \mathrm{H}=644 \mu \mathrm{m} ; \mathrm{H} / \mathrm{L}=0.6$.

LV: $\mathrm{L}=838-1068 \mu \mathrm{m} ; \mathrm{H}=520-695 \mu \mathrm{m} ; \mathrm{H} / \mathrm{L}=0.62-0.63$.

\section{Occurrence}

Romanian Continental Shelf, Black Sea, Rhaetian, Late Triassic (this paper).

\section{Remarks}

Hiatobairdia sp. 2 is characterized by its very high and nearly symmetrical AB and PB, which clearly relates it to Hiatobairdia arcuata Kristan-Tollmann in Kristan-Tollmann et al., 1980 from the Rhaetian of Iran (Kristan-Tollmann et al. 1980). However, Hiatobairdia sp. 2 is differentiated from it by having the lateral surface not overhanging the ventral margin, absence of postero-ventral thickening and less pronounced antero-dorsal and postero-dorsal concavities. Hiatobairdia sp. 2 is undeniably a new species, but we lack enough material to define its diagnostic characters.

\section{Hiatobairdia sp. 3}

Fig. 8F

\section{Material examined}

ROMANIA 1 complete carapace; Black Sea, Romanian Continental Shelf, borehole 817LV, sample CM31B; Rhaetian, Upper Triassic; MNHN.F.F63232 • 1 RV; same locality as for preceding but sample CM31C; Rhaetian, Upper Triassic; MNHN.F.F63350.

\section{Dimensions}

$\mathrm{RV}: \mathrm{L}=1152 \mu \mathrm{m} ; \mathrm{H}=678 \mu \mathrm{m} ; \mathrm{H} / \mathrm{L}=0.59$.

$\mathrm{LV}: \mathrm{L}=1152 \mu \mathrm{m} ; \mathrm{H}=627 \mu \mathrm{m} ; \mathrm{H} / \mathrm{L}=0.54$.

\section{Occurrence}

Romanian Continental Shelf, Black Sea, Rhaetian, Upper Triassic (this paper).

\section{Remarks}

Hiatobairdia sp. 3 is very close to several species already known from the literature, but the conspecificity of our material with these species is impossible to ascertain because the RV of cthe omplete carapace is broken posteriorly. Hiatobairdia sp. 3 is relatively close to Hiatobairdia subsymmetrica KristanTollmann in Kristan-Tollmann et al., 1980 from the Rhaetian of Iran (Kristan-Tollmann et al. 1980), but the presence of the diagnostic ridge underlying the ventral margin is not verifiable here and our specimens have a relatively shorter and larger $\mathrm{AB}$, as well as a shorter and less pointed $\mathrm{PB}$. The slight indentation visible at the PVB of the RV could relate Hiatobairdia sp. 3 to Hiatobairdia labrifera Kristan-Tollmann in Kristan-Tollmann et al., 1980 from the Rhaetian of Iran (Kristan-Tollmann et al. 1980), but it is 
difficult to ascertain that the observed indentation is not related to preservation bias. For these reasons, and until additional material can be observed, the present species is kept in open nomenclature.

Genus Histriabairdia Forel gen. nov. urn:1sid:zoobank.org:act:E3BC5C1B-2B5E-4A14-AF20-94748EC55F14

\section{Type species}

Histriabairdia pontuseuxinusensis Forel gen. et sp. nov.

\section{Diagnosis}

A moderately calcified bairdiid genus, subrectangular, with antero-ventral and postero-ventral margins laterally compressed and bordered by marginal denticles at both valves; anterior margin large; surface smooth, reticulate to spinose.

\section{Etymology}

This genus is named after the Histria Depression, where the studied borehole was drilled.

\section{Species included}

- Anchistrocheles sp. A in Bolz 1971 from the Rhaetian of Austria (Bolz 1971a, 1971b)

- Anchistrocheles? spinosa Sheppard in Brand, 1990 from the Bathonian, Middle Jurassic, of France (Brand 1990)

- Anchistrocheles sp. A from the Bathonian, Middle Jurassic, of India (Khosla \& Jakhar 1999; Khosla et al. 2009)

- Anchistrocheles? tuningensis Beher, 2004 from the Sinemurian, Early Jurassic, of Germany and Switzerland (Beher 2004)

- Anchistrocheles sp. B from the Bajocian-Bathonian, Middle Jurassic, of India (Khosla et al. 2006, 2009)

Fig. 8 (opposite page). SEM micrographs of ostracods from borehole 817 Lebăda Vest, drill core CM31, western portion of Black Sea shelf, Rhaetian, Late Triassic. All specimens are housed in the collections of the Muséum national d'histoire naturelle, Paris, France (MNHN). A. Fabalicypris cf. triassica Bolz, 1971, external view of a left valve, sample CM31 A (MNHN.F.F63228). B. Hiatobairdia sp. 1, right lateral view of a carapace, sample CM31B (MNHN.F.F63229). C-E. Hiatobairdia sp. 2. C. Right lateral view of a carapace, sample CM31B (MNHN.F.F63230). D. Same specimen, dorsal view. E. External view of a left valve, sample CM31B (MNHN.F.F63231). F. Hiatobairdia sp. 3, right lateral view of a carapace, sample CM31B (MNHN.F.F63232). G-O. Histriabairdia pontuseuxinusensis Forel gen. et sp. nov. G. External view of a left valve, sample CM31C (MNHN.F.F63233). H. Right lateral view of a complete carapace, sample CM31C (MNHN.F.F63234). I. External view of a right valve, sample CM31C (MNHN.F.F63235). J. Right lateral view of a complete carapace, sample CM31C (MNHN.F.F63236). K. External view of a left valve, sample CM31C (MNHN.F.F63237). L. Holotype, right lateral view of a complete carapace, sample CM31B (MNHN.F.F63238). M. Same specimen, dorsal view. N. Paratype, external view of a left valve, sample CM31B (MNHN.F.F63239). O. Same specimen, inner view. P-R. Histriabairdia gen nov. sp. 1. P. External view of a right valve, sample CM31C (MNHN.F.F63240). Q. Right lateral view of a complete carapace, sample CM31C (MNHN.F.F63241). R. Same specimen, dorsal view. S-U. Histriabairdia gen. nov. sp. 2. S. Right lateral view of a carapace broken anteriorly and posteriorly, sample CM31C (MNHN.F.F63242). T. Right lateral view of a carapace broken anteriorly and posteriorly, sample CM31C (MNHN.F.F63243).

U. External view of a broken right valve, sample CM31C (MNHN.F.F63244). Scale bars: $100 \mu \mathrm{m}$. 


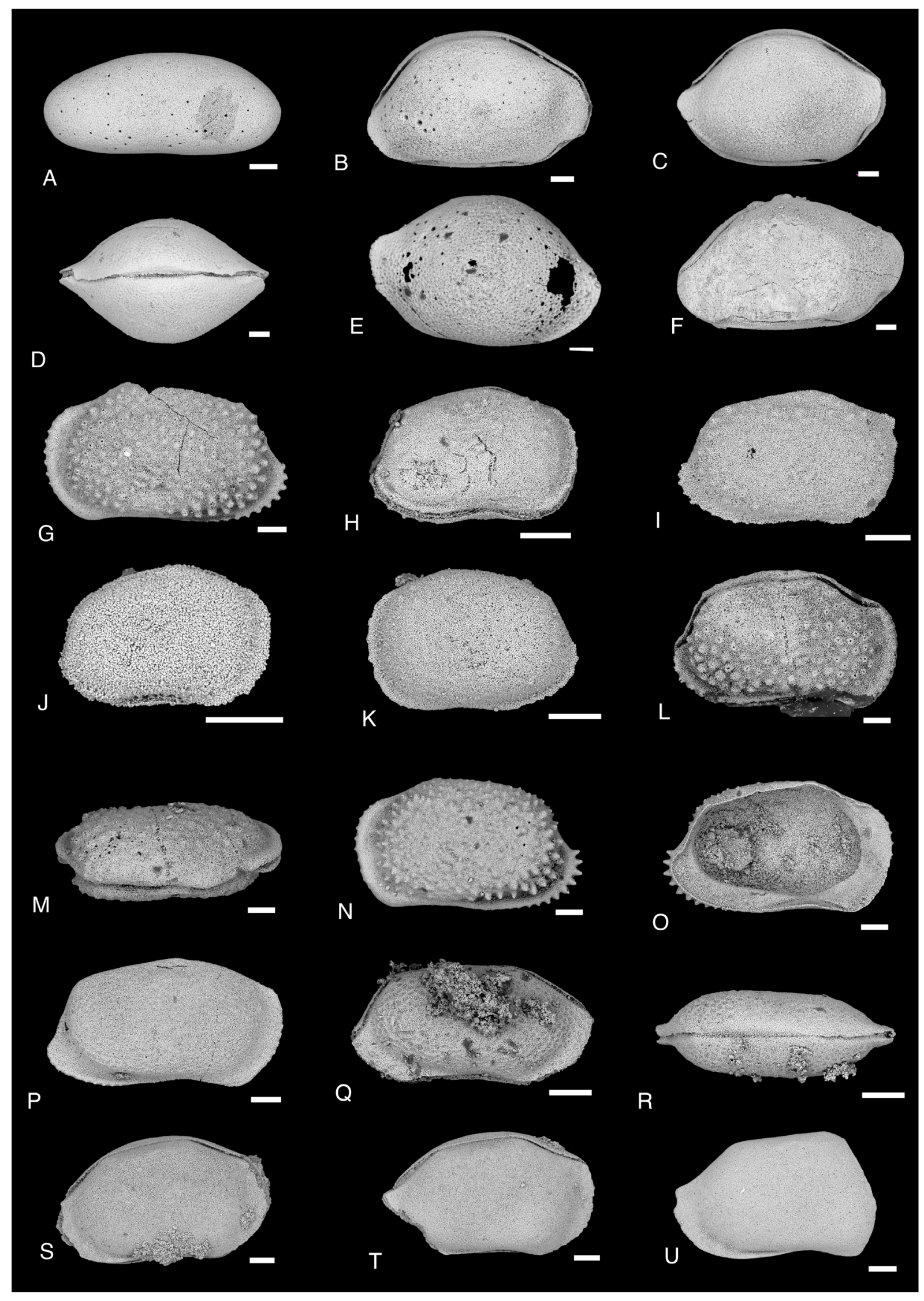


- "Anchistrocheles" gemmellaroi Crasquin in Crasquin et al., 2018 from the Carnian of Sicily (Crasquin et al. 2018)

- Histriabairdia pontuseuxinusensis Forel gen. et sp. nov. from the Rhaetian of the Black Sea (this paper)

- Histriabairdia gen. nov. sp. 1 from the Rhaetian of the Romanian Black Sea shelf (this paper)

- Histriabairdia gen. nov. sp. 2 from the Rhaetian of the Romanian Black Sea shelf (this paper)

\section{Questionable species}

- Pustulobairdia subparalella Kristan-Tollmann, 1970 from the Ladinian, Middle Triassic, of the Dolomites (Kristan-Tollmann 1970): the general outline of this species is in line with the diagnositic features of Histriabairdia gen. nov. but the antero-ventral and postero-ventral compressions are not mentioned in its description and not visible on the drawings provided by Kristan-Tollmann (1970)

- Anchistrocheles? sp. in Beher 2004 from the Sinemurian, Early Jurassic, of Germany and Switzerland (Beher 2004) is questionably included because this species is only shown in inner view

- Anchistrocheles sp. 1 in Forel et al. 2019 from the Carnian of Turkey (Forel et al. 2019a): anteroventral and postero-ventral compressions are lacking, but the overall morphology is reminiscent of that of Histriabairdia gen. nov.; the size of the unique $\mathrm{LV}(\mathrm{L}=463 \mu \mathrm{m} ; \mathrm{H}=275 \mu \mathrm{m}$, excluding marginal spines) and the very narrow calcified inner lamella indicate that it might be an immature instar, which could explain the absence of a lateral compression as seen in the taxa described in the present contribution.

\section{Remarks}

All species from the literature re-attributed to Histriabairdia gen. nov. were originally attributed, tentatively or not, to Anchistrocheles Brady \& Norman, 1889 emend. Maddocks 1976 (type species Anchistrocheles fumata Brady \& Norman, 1889 subsequently designated by Brady 1890). Recent species of Anchistrocheles are known for instance from the North Sea, Irish Sea and English Channel (Brady \& Norman 1889), Madagascar (e.g., Brady 1890; Maddocks 1969), Bermuda (Maddocks 1976), Mozambique (Maddocks 1969) and the Mediterranean Sea (e.g., Breman 1975; Aiello et al. 1996). Fossil species are for instance known from the Neogene of Hawaii (Brady 1890), the Plio-Pleistocene of the Mediterranean Basin (Aiello et al. 1996; Sciuto \& Pugliese 2013), the Pleistocene of Italy (e.g., Colalongo 1965; Greco et al. 1974; Sciuto 2012, 2015), Rhodes (Mostafawi 1989) and Japan (Yajima 1987), the Miocene of Australia (Whatley \& Downing 1984; Warne 1990), the Eocene of the USA (Swain 2000) and the Late Cretaceous of Poland (Herrig 1992). Older species from the Triassic-Jurassic time interval have been tentatively attributed to the genus Anchistrocheles in the Bathonian, Middle Jurassic, of France (Brand 1990) and India (Khosla \& Jakhar 1999; Khosla et al. 2009), the BathonianBajocian, Middle Jurassic, of India (Khosla et al. 2006, 2009), the Sinemurian, Early Jurassic, of Germany and Switzerland (Beher et al. 2001; Beher 2004), the Rhaetian, Late Triassic, of Austria (Bolz 1971a, 1971b), and the Carnian, Late Triassic, of Sicily (Crasquin et al. 2018) and Turkey (Forel et al. 2019a). The carapace of Anchistrocheles is small, delicate, mirror-smooth, laterally compressed, streamlined, reniform in outline, with extremely compressed margins, but this genus is mainly diagnosed by characters of the inner part of their valves (broad fused marginal zone, abundant straight radial pore canals, bythocyprid adductor muscle-scar pattern) and appendages (Maddocks 1969; Maddocks \& Illife 1991). Anchistrocheles has an overall juvenile aspect as compared with Bairdiinae (Maddocks 1969). Warne (1990) furthermore considered Anchistrocheles s. str. as including forms with a reniform to subreniform outline, narrow compression along the anterior, posterior and ventral margins, and a very broad inner lamella except in the middle portion of the dorsal margin. Inner structures are only partly accessible for Histriabairdia gen. nov., but the type species displays an inner lamella that does not extend as far dorsally as in the conception of Warne (1990), excluding it from Anchistrocheles. Histriabairdia spinosa (Sheppard in Brand, 1990) gen. et comb. nov. from the Bathonian, Middle Jurassic, of France (Brand 1990) has muscle scars described has "typical bythocyprid-type with anterior row of 3 horizontal 
oval scars and 1 posteroventral scar". The inner structures of these Triassic-Jurassic forms are visible in Beher (2004), but their preservation is poor and only the extension of the inner lamella is visible.

The subfamilial position of Anchistrocheles has been unstable and it is now placed in the Pussellinae: they are medium to small-size Bairdiidae with a smooth or weakly punctate, elongate, laterally compressed, thin-walled carapace, conspicuous ventral indentation and anteroventral angle, normal pores funnelshaped or with low, flat wall, width of fused zone and number of distinct radial pore canals proportional to size of carapace, bythocyprid muscle-scar pattern (5 scars, adductor scars arranged in an anterior row of three horizontal scars plus one posteroventral scar, all scars may be divided but not separated; Maddocks 1969) and an adont hinge (Danielopol in Maddocks 1976). Pussellinae are adapted to phytal, interstitial and possibly cryptic habitats, mostly in tropical reefs, as shown by the morphological adaptations of their antennae, posterior legs and the laterally compressed, streamlined, mirror-smooth, fragile carapace with broadened marginal zone of concrescence (Maddocks 1976; Maddocks \& Illife 1991). Conversely, the Bairdiinae are ovate to subhexagonal in lateral view, with LV larger than RV and overlapping it dorsally and ventrally, usually of different shapes; the RV hinge is a simple bar with a dorsal groove and the LV hinge is an incised groove with a dorsal shelf and ventro-terminal triangular sloping platforms; the adductor muscle-scar pattern is characteristically composed of 8-10 scars arranged in three anterior plus one postero-ventral rows of 2-3 scars each (Maddocks 1969). According to the emended diagnoses of the Pussellinae Danielopol in Maddocks, 1976 and of Anchistrocheles (Maddocks 1976), they are characterized by a smooth or weakly punctate carapace. This character clearly excludes most of the present species from the actual genus Anchistrocheles and from the Pussellinae. The spinose anteroventral and postero-ventral margins are reminiscent of recent Bairdiidae (e.g., Maddocks 1969).

Histriabairdia gen. nov. differs from Bairdia McCoy, 1844 by its conspicuous AV and PV lateral compressions on both valves, overall rectangular outline of the carapace and surface ornamentation ranging from smooth to reticulate and spinose. Pustulobairdia Sohn, 1960 differs from Bairdia by having its surface covered with pustules. However, Pustulobairdia also lacks the AV and PV lateral compressions and rows of spines that are characteristic of Histriabairdia gen. nov. Furthermore, the visible pustules expressed at the surface of the type species are specific characters, contrary to the interpretation of Sohn (1960) for Pustulobairdia. Lobobairdia Kollmann, 1963 is diagnosed as having $\mathrm{AV}$ and PV laterally compressed into deep furrows. However, Lobobairdia has a highly convex dorsal margin with a much lower anterior margin.

Histriabairdia pontuseuxinusensis Forel gen. et sp. nov. urn:lsid:zoobank.org:act:2A9EE0A7-227E-41AC-840C-3F3F93A26790

Fig. $8 \mathrm{G}-\mathrm{O}$

Pustulobairdia subparallela - Harloff \& Jäger 1994: pl. 2, figs 7-8. [not Kristan-Tollmann, 1970]

\section{Diagnosis}

Dorsal margin tripartite and lateral surface spinose except on the smooth, laterally compressed anteroventral and postero-ventral surfaces, anterior margin subvertical.

\section{Etymology}

From Pontus Euxinus, one of the Latin names for the Black Sea, where borehole 817LV was drilled.

\section{Material examined}

\section{Holotype}

ROMANIA 1 complete carapace; Black Sea, Romanian Continental Shelf, borehole 817LV, sample CM31B; Rhaetian, Upper Triassic; MNHN.F.F63238. 


\section{Paratype}

ROMANIA • 1 LV; same collection data as for preceding; Rhaetian, Upper Triassic; MNHN.F.F63239.

\section{Other material}

ROMANIA - $1 \mathrm{LV}$; same locality as for holotype but sample CM31C; Rhaetian, Upper Triassic; MNHN.F.F63233 - 1 LV; same collection data as for preceding; Rhaetian, Upper Triassic; MNHN.F.F63237 - 1 complete carapace; same collection data as for preceding; Rhaetian, Upper Triassic; MNHN.F.F63234 - 1 complete carapace; same collection data as for preceding; Rhaetian, Upper Triassic; MNHN.F.F63236 - 1 RV; same collection data as for preceding; Rhaetian, Upper Triassic; MNHN.F.F63235 - 5 complete carapaces; same locality as for preceding but samples CM31A, CM31B and CM31C; Rhaetian, Upper Triassic; MNHN.F.F63351.

\section{Dimensions}

See Fig. 3E.

\section{Description}

Carapace subrectangular, large, inflated laterally except along compressed antero-ventral and posteroventral margins; carapace preplete with $\mathrm{H}_{\max }$ located at antero-dorsal angulation; $\mathrm{L}_{\max }$ located below mid-height; dorsal margin long and tripartite at both valves; LV larger than RV, overlapping it along dorsal margin with maximum along DB and ventral margin with maximum at oral concavity; DB long (43-55\% of $\mathrm{L}_{\max }$ ), straight at RV and straight to slightly convex at LV, slightly inclined posteriorly (between $20^{\circ}$ in small specimens and $5^{\circ}$ in largest forms); ADB shorter (34-43\% of $\mathrm{L}_{\max }$ ), concave at both valves, more strongly in adults that in younger instars; PDB short (8-20\% of $\left.\mathrm{L}_{\text {max }}\right)$, steeply bent posteriorly (from $60^{\circ}$ to close to vertical in smallest instars) with terminal concavity more clearly expressed in adults; antero-dorsal and postero-dorsal angulations rounded; AB large and subvertical, with apex located in upper third of $\mathrm{H}_{\max }$; AVB underlined by series of marginal denticles on both valves and bordered by a laterally compressed area; $\mathrm{PB}$ narrower, with maximum of convexity in lower third of $\mathrm{H}_{\text {max }}$ on both valves, underlined by a narrow laterally compressed zone; 9 to 10 marginal denticles aligned along PVB, one located above PB; ventral margin long and sinuous with oral concavity located in front of mid-L, bordered by a laterally compressed zone that extends from anterior maximum of convexity to posterior one, attenuated at oral concavity; laterally inflated surface covered with spinose pustules arranged concentrically parallel to free margins except on smooth compressed zones along antero-ventral and postero-ventral margins; antero-ventral and postero-ventral margins bordered by row of sharp spines, length of which decreases ventrally, their number increasing through ontogeny; in inner view, calcified lamella large along anterior and posterior margins, weaker along oral concavity, vestibulum large; central muscle scar not visible; hinge not visible and bairdoppilate auxiliary structure absent.

\section{Occurrence}

Tyrol, Austria, Hettangian, Early Jurassic (Harloff \& Jäger 1994); Romanian Continental Shelf, Black Sea, Rhaetian, Upper Triassic (this paper).

\section{Remarks}

The short spines across the lateral surface of Histriabairdia pontuseuxinusensis gen. et sp. nov. are reminiscent of those in the Palaeozoic genus Pustulobairdia Sohn, 1960. Pustulobairdia subparallella Kristan-Tollmann, 1970 was described from the Ladinian, Middle Triassic, of the Dolomites, Italy (Kristan-Tollmann 1970) but lacks AD angulation, so that the DB and ADB are in line. On the contrary, specimens attributed to P. subparallella from the Hettangian, Early Jurassic, of Tyrol (Harloff \& Jäger 1994) have a well-expressed AD angulation on both valves, also expressed at young stages, similarly to in 
the Black Sea material. Therefore, this Jurassic material is not conspecific with $P$. subparallella, which is restricted to the Ladinian of the Dolomites. Conversely, specimens from the Hettangian are attributed to Histriabairdia pontuseuxinusensis gen. et sp. nov. The surface ornamentation of $H$. pontuseuxinusensis gen. et sp. nov. is reminiscent of that in Anchistrocheles sp. 1 from the Carnian of Turkey (Forel et al. 2019a), but this Carnian species is significantly smaller $(\mathrm{L}=463 \mu \mathrm{m}, \mathrm{H}=275 \mu \mathrm{m})$ and shorter $(\mathrm{H} / \mathrm{L}=$ 0.6 ), with smaller and more abundant pustules covering the entire lateral surface. The very narrow calcified inner lamella of the only valve (LV) from the Carnian of Turkey implies that the specimen is a relatively young instar. Histriabairdia spinosa (Sheppard in Brand, 1990) gen. et comb. nov. from the Bathonian, Middle Jurassic, of France (Brand 1990) is also defined by its pustulose surface, but it differs from $H$. pontuseuxinusensis gen. et sp. nov. by having much smaller spines.

The large distribution of the $\mathrm{H}$ and $\mathrm{L}$ scatter plot indicates the co-occurrence of several ontogenetic stages for Histriabairdia pontuseuxinusensis gen. et sp. nov. (Fig. 3E). However, the rarity of specimens of intermediate dimensions does not reasonably allow a discrimination of the stages. The holotype (Fig. 8L-M) and the paratype (Fig. 8N-O) are among the largest specimens and are thus considered as adults. The ontogenetic development of $H$. pontuseuxinusensis gen. et sp. nov. is marked by the progressive strengthening of the lateral spines, densification of the surface coverage, widening of the lateral compressions along AVB and PVB, an increase in the number of marginal spines and an upward migration of the PB. Jurassic specimens have a slightly higher $\mathrm{H} / \mathrm{L}$ ratio for both valves (Fig. 3E), which may relate to distinct environmental conditions.

Histriabairdia gen. nov. sp. 1

Fig. 8P-R

\section{Material examined}

ROMANIA • 1 RV; Black Sea, Romanian Continental Shelf, borehole 817LV, sample CM31C; Rhaetian, Upper Triassic; MNHN.F.F63240 • 1 complete carapace; same collection data as for preceding; Rhaetian, Upper Triassic; MNHN.F.F63241.

\section{Dimensions}

RV: $\mathrm{L}=570-800 \mu \mathrm{m} ; \mathrm{H}=275-570 \mu \mathrm{m} ; \mathrm{H} / \mathrm{L}=0.48-0.54$.

$\mathrm{LV}: \mathrm{L}=575 \mu \mathrm{m} ; \mathrm{H}=292 \mu \mathrm{m} ; \mathrm{H} / \mathrm{L}=0.51$.

\section{Occurrence}

Romanian Continental Shelf, Black Sea, Rhaetian, Upper Triassic (this paper).

\section{Remarks}

The two specimens of Histriabairdia gen. nov. sp. 1 have different dimensions and correspond to distinct ontogenetic stages. This species is characterized by its relatively slender carapace, long and straight to convex ADB and reticulate surface. The reticulate surface of Histriabairdia gen. nov. sp. 1 is reminiscent of that of Histriabairdia gemmellaroi (Crasquin in Crasquin et al., 2018) gen. et comb. nov. from the Late Carnian of Sicily (Crasquin et al. 2018). However, Histriabairdia gemmellaroi gen. et comb. nov. is comparatively shorter $(\mathrm{H} / \mathrm{L}=0.61)$ with ADB shorter and concave, postero-dorsal angulation less expressed at both valves and small tubercles developed in the antero-dorsal and dorsal areas of the surface. Histriabairdia gen. nov. sp. 1 is very close to Histriabairdia tuningensis (Beher, 2004) gen. et comb. nov. from the Sinemurian, Early Jurassic, of Germany and Switzerland (Beher 2004), as shown by its similar elongation and long, straight ADB. However, the marginal compressions along AVB and PVB are narrower, anterior maximum of curvature is located lower and the surface is punctate rather than reticulate. 
Histriabairdia gen. nov. sp. 2

Fig. 8S-U

\section{Material examined}

ROMANIA - 1 broken carapace; Black Sea, Romanian Continental Shelf, borehole 817LV, sample CM31C; Rhaetian, Upper Triassic; MNHN.F.F63242 - 1 broken carapace; same collection data as for preceding; Rhaetian, Upper Triassic; MNHN.F.F63243 1 broken RV; same collection data as for preceding; Rhaetian, Upper Triassic; MNHN.F.F63244 • 2 RV; same collection data as for preceding; Rhaetian, Upper Triassic; MNHN.F.F63352.

\section{Occurrence}

Romanian Continental Shelf, Black Sea, Rhaetian, Upper Triassic (this paper).

\section{Remarks}

No complete specimen of Histriabairdia gen. nov. sp. 2 has been found, so no dimensions are provided. Histriabairdia gen. nov. sp. 2 is close to Anchistrocheles sp. B in Khosla et al. 2006 (here considered a member of Histriabairdia gen. nov.) from the Bajocian-Bathonian interval, Middle Jurassic, of India (Khosla et al. 2006), from which it differs by having a more elongate and caudate posterior extremity, a more rounded AVB and by lacking the median vertical 'sulcus'.

Genus Isobythocypris Apostolescu, 1959

\section{Type species}

Isobythocypris unispinata Apostolescu, 1959 by original designation.

\section{Isobythocypris sp.}

Fig. 9A

\section{Material examined}

ROMANIA - 1 complete carapace; Black Sea, Romanian Continental Shelf, borehole 817LV, sample CM31C; Rhaetian, Upper Triassic; MNHN.F.F63245 • 1 complete carapace; same collection data as for preceding; Rhaetian, Upper Triassic; MNHN.F.F63353.

\section{Dimensions}

RV: $\mathrm{L}=470-780 \mu \mathrm{m} ; \mathrm{H}=268-427 \mu \mathrm{m} ; \mathrm{H} / \mathrm{L}=0.55-0.57$.

$\mathrm{LV}: \mathrm{L}=480-798 \mu \mathrm{m} ; \mathrm{H}=275-466 \mu \mathrm{m} ; \mathrm{H} / \mathrm{L}=0.58$.

\section{Occurrence}

Romanian Continental Shelf, Black Sea, Rhaetian, Upper Triassic (this paper).

\section{Remarks}

Isobythocypris Apostolescu, 1959 is mainly distinguished from other bairdiid genera by its lophodont hinge (Apostolescu 1959). More recently, Ainsworth (1990) clarified that Isobythocypris has a subrectangular to elongate subrectangular lateral outline. Only complete carapaces have been retrieved from the CM31 sample so it is impossible to characterize the nature of the hinge in the present material. However, because of its sub-rectangular outline it is attributed to Isobythocypris. Isobythocypris sp. resembles I. dorsoconvexa Ainsworth, 1987 and I. pliensbachensis Ainsworth, 1987 both from the Pliensbachian, Early Jurassic, of the Fastnet Basin, offshore Southwest Ireland (Ainsworth 1987), from which it differs by its shorter oral concavity, less pronounced lateral compression along AVB and its 
visible, although poorly expressed, dorsal angulations. Isobythocypris sp. is also close to Bairdiacypris triassica postera Herrig, 1979 from the Upper Sinemurian, Early Jurassic, of Thüringen, Germany (Herrig 1979b), but it differs in being more massive and less elongate, with a longer posterior end and a more tapered anterior end.

Isobythocypris atalantella Forel sp. nov.

urn:Isid:zoobank.org:act:E98F39D0-EF52-4BEC-A66B-439D4AD1D442

Fig. 9B-I

\section{Diagnosis}

A new species of Isobythocypris with long and slightly arched dorsal margin, relatively large posterior border.

\section{Etymology}

From A A $\tau \lambda \alpha \alpha^{\prime} \tau \tau \eta$ / Átalántê, the only Augonaut woman.

\section{Material examined}

Holotype

ROMANIA 1 complete carapace; Black Sea, Romanian Continental Shelf, borehole 817LV, sample CM31B; Rhaetian, Upper Triassic; MNHN.F.F63246.

\section{Paratype}

ROMANIA - 1 complete carapace; same collection data as for holotype; Rhaetian, Upper Triassic; MNHN.F.F63247.

\section{Other material}

ROMANIA - 1 complete carapace; same collection data as for holotype; Rhaetian, Upper Triassic; MNHN.F.F63248 • 1 complete carapace; same collection data as for holotype; Rhaetian, Upper Triassic; MNHN.F.F63249 • 1 complete carapace; same collection data as for holotype; Rhaetian, Upper Triassic; MNHN.F.F63251 - 1 complete carapace; same locality as for preceding but sample CM31C; Rhaetian, Upper Triassic; MNHN.F.F63250 9 complete carapaces; same locality as for preceding but samples CM31A, CM31B and CM31C; Rhaetian, Upper Triassic; MNHN.F.F63354.

\section{Dimensions}

See Fig. 3F.

\section{Description}

Carapace of medium size, ovoid in lateral view, with $\mathrm{H}_{\max }$ around mid- $\mathrm{L}, \mathrm{L}_{\text {max }}$ slightly below mid- $\mathrm{H}, \mathrm{W}_{\max }$ slightly posterior to mid-L; LV larger than RV, overlapping along dorsal margin and oral concavity, with interruption at AVB and PVB. Dorsal margin long and slightly convex, lacking angulations at LV, with weak angulations at RV resulting from tight folds of overlapping LV; antero-dorsal slope gentle in large specimens $\left( \pm 10^{\circ}\right)$, slightly steeper in smaller ones $\left( \pm 20^{\circ}\right)$; DB straight, somewhat sloping posteriorly $\left( \pm 25-35^{\circ}\right)$; postero-dorsal slope short, steep, often poorly differentiated; anterior margin large, only slightly tapered ventrally, with poorly expressed bairdiid morphology and maximum of curvature at mid-H; ventral margin long and sinuous, with median oral concavity expressed on both valves, only slightly more in RV; AVB only slightly raised, PVB horizontal; posterior end narrowly rounded. Inner structures not observed. Surface smooth.

\section{Occurrence}

Romanian Continental Shelf, Black Sea, Rhaetian, Upper Triassic (this paper). 


\section{Remarks}

Isobythocypris atalantella sp. nov. is relatively close to the species of Bythocypris illustrated in Bolz (1971b). Of them, Bythocypris sp. A is only shown as inner views (Bolz 1971b: pl. 8, figs 118-119), which makes a comparison difficult. However, Isobythocypris atalantella sp. nov. differs from Bythocypris sp. A and Bythocypris sp. B from the Rhaetian of the Northern Calcareous Alps (Bolz 1971b) by its narrower and uniformly convex posterior margin, which is close to vertical in both species of Bythocypris. Isobythocypris atalantella sp. nov. also differs from Bythocypris ubiquefrequens Bolz, 1971 from the Rhaetian of the Northern Calcareous Alps (Bolz 1971b) in having a longer and less curved dorsal margin, a less marked bairdiid anterior margin and a larger posterior maximum of curvature. Isobythocypris atalantella sp. nov. is morphologically close to Isobythocypris? sp. in Dreyer 1967 from the Early Domerian, Early Jurassic, of Germany (Dreyer 1967) but the PB of Isobythocypris? sp. is nearly vertical, with the maximum of curvature narrower and located more ventrally. It also differs from Isobythocypris elongata (Blake, 1876) from the Early Jurassic of Yorkshire (Blake 1876) by having a larger and not angulate posterior border. Isobythocypris atalantella sp. nov. also differs from Bythocypris faba Knitter, 1983 from the Toarcian, Early Jurassic, of Southern Germany (Knitter 1983) by its more homogeneous convex dorsal margin, anterior maximum of convexity located higher and posterior border located lower and less bairdiid.

The H/L scatter plot of all measurable specimens of Isobythocypris atalantella sp. nov. (Fig. 3F) documents the occurrence of at least five ontogenetic stages, from A-4 to adult. The holotype (Fig. 9B-C) is the largest known adult. Conversely, the paratype (Fig. 9D) may correspond to an A-1 stage. The ontogeny of Isobythocypris atalantella sp. nov. is marked by the overall elongation of the carapace, narrowing of the PB and accentuation of the median oral concavity on both valves.

Genus Lobobairdia Kollmann, 1963

\section{Type species}

Lobobairdia salinaria Kollmann, 1963 by original designation.

Fig. 9 (opposite page). SEM micrographs of ostracods from borehole 817 Lebăda Vest, drill core CM31, western portion of Black Sea shelf, Rhaetian, Late Triassic. All specimens are housed in the collections of the Muséum national d'histoire naturelle, Paris, France (MNHN). A. Isobythocypris sp., right lateral view of a carapace, sample CM31C (MNHN.F.F63245). B-I. Isobythocypris atalantella Forel sp. nov. B. Holotype, right lateral view of a carapace, sample CM31B (MNHN.F.F63246). C. Same specimen, ventral view. D. Paratype, right lateral view of a carapace, sample CM31B (MNHN.F.F63247). E. Right lateral view of a carapace, sample CM31B (MNHN.F.F63248). F. Right lateral view of a carapace, sample CM31B (MNHN.F.F63249). G. Right lateral view of a carapace, sample CM31C (MNHN.F.F63250). H. Right lateral view of a carapace, sample CM31B (MNHN.F.F63251). I. Same specimen, dorsal view. J-M. Lobobairdia salinara Kollmann, 1963. J. External view of a right valve, sample CM31B (MNHN.F.F63252). K. External view of a left valve, sample CM31B (MNHN.F.F63253). L. External view of a left valve, sample CM31B (MNHN.F.F63254). M. External view of a left valve, sample CM31C (MNHN.F.F63255). N. Lobobairdia? sp. 1, right lateral view of a carapace, sample CM31B (MNHN.F.F63256). O. Lobobairdia sp. 2, right lateral view of a carapace, sample CM31C (MNHN.F.F63257). P. Mirabairdia sp., external view of a left valve, sample CM31A(MNHN.F.F63258). Q-U. Petasobairdia amazonella Forel sp. nov. Q. Right lateral view of a carapace, sample CM31C (MNHN.F.F63259). R. Right lateral view of a carapace, sample CM31A(MNHN.F.F63260). S. Paratype, right lateral view of a carapace, sample CM31B (MNHN.F.F63261). T. Same specimen, dorsal view. U. Right lateral view of a carapace, sample CM31B (MNHN.F.F63262). Scale bars: $100 \mu \mathrm{m}$. 


\section{FOREL M.-B. \& GRĂDINARU E., Late Triassic ostracods of North Dobrogean Orogen}

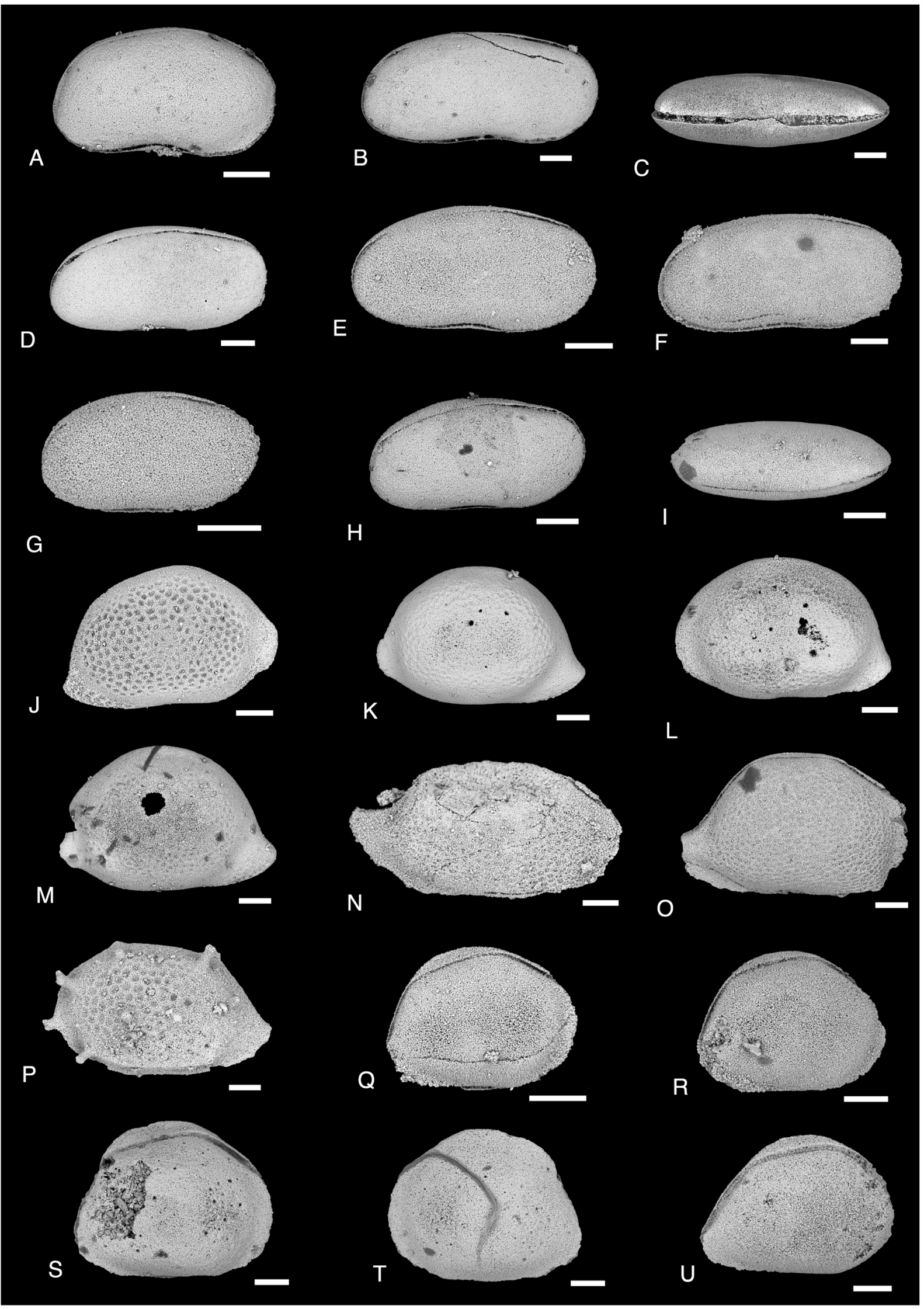


Lobobairdia salinaria Kollmann, 1963

Fig. 9J-M

Lobobairdia salinaria Kollmann 1963: 169, pl. 6, figs 9-12.

Ptychobairdia? sp. - Kollmann 1960: 102, pl. 27, figs 5-8.

Lobobairdia salinaria - Bolz 1969: 419, pl. 1, fig. 7-10. - Urlichs 1972: 675, pl. 1, fig. 1. — Mette \& Mohtat-Aghai 1999: pl. 5, figs 9-10. — Zorn 2010: 271, pl. 7, figs 1-4.

non Lobobairdia salinaria - Sebe et al. 2013: 358.

\section{Material examined}

ROMANIA • 1 RV; Black Sea, Romanian Continental Shelf, borehole 817LV, sample CM31B; Rhaetian, Upper Triassic; MNHN.F.F63252 - $1 \mathrm{LV}$; same collection data as for preceding; Rhaetian, Upper Triassic; MNHN.F.F63253 - $1 \mathrm{LV}$; same collection data as for preceding; Rhaetian, Upper Triassic; MNHN.F.F63254 • $1 \mathrm{LV}$; same locality as for preceding but sample CM31C; Rhaetian, Upper Triassic; MNHN.F.F63255 1 broken RV, 5 broken LV; same locality as for preceding but samples CM31A, CM13B and CM31C; Rhaetian, Upper Triassic; MNHN.F.F63355.

\section{Dimensions}

RV: $\mathrm{L}=584 \mu \mathrm{m} ; \mathrm{H}=373 \mu \mathrm{m} ; \mathrm{H} / \mathrm{L}=0.64$.

$\mathrm{LV}: \mathrm{L}=615-678 \mu \mathrm{m} ; \mathrm{H}=405-454 \mu \mathrm{m} ; \mathrm{H} / \mathrm{L}=0.66-0.67$.

\section{Occurrence}

Rhaetian, Late Triassic, Zlambach Formation, Hallstatt, Salzberg, Upper Austria, Austria (Kollmann 1960, 1963; Bolz 1969; Zorn 2010); Austria, Rhaetian, Upper Triassic (Urlichs 1972); Kössen Formation, Northern Calcareous Alps, Tyrol, Austria, Rhaetian, Upper Triassic (Mette \& Mohtat-Aghai 1999); Romanian Continental Shelf, Black Sea, Rhaetian, Upper Triassic (this paper).

\section{Remarks}

The present record is the first known occurrence of Lobobairdia salinaria outside of Austria. This species appears to be typical for the Rhaetian of Western Europe. It is mentioned as part of the Aegean, Lower Anisian, Middle Triassic assemblage of the North Dobrogean Orogen (Sebe et al. 2013). However, such an early occurrence prescribes extreme care as it would extend the range of this species to more than 40 Ma. Because this specimen was not illustrated, we consider this Middle Triassic occurrence as invalid.

Bolz (1969) plotted the dimensions of 169 specimens of Lobobairdia salinaria and identified five ontogenetic stages, from A-4 to adult. The only complete RV obtained from the present analysis corresponds to an A-1 stage based on the ranges provided by Bolz (1969). Conversely, the three LV correspond to the A-2 stage as defined by Bolz (1969). The largest LV shown in Fig. 9M bears a drill hole, which is described in the discussion chapter.

Genus Mirabairdia Kollmann, 1963

\section{Type species}

Mirabairdia pernodosa Kollmann, 1963 by original designation.

\section{Mirabairdia sp.}

Fig. 9P

\section{Material examined}

ROMANIA • 1 LV; Black Sea, Romanian Continental Shelf, borehole 817LV, sample CM31 A; Rhaetian, Upper Triassic; MNHN.F.F63258. 


\section{Dimensions}

$\mathrm{L}=687 \mu \mathrm{m} ; \mathrm{H}=419 \mu \mathrm{m} ; \mathrm{H} / \mathrm{L}=0.61$.

\section{Occurrence}

Romanian Continental Shelf, Black Sea, Rhaetian, Upper Triassic (this paper).

\section{Remarks}

Only one LV of the present species was found, in sample CM31A, which hampers its attribution to any known species. It is close to Triebelina sp. F in Bolz 1971 from the Rhaetian, Late Triassic of Tyrol (Bolz 1971a), later re-attributed to the newly erected Triebelina (Nodobairdia) nodata Bolz, 1971 (Bolz 1971b). However, our specimen is significantly smaller than the specimens illustrated in Bolz (1971a, 1971b), which all exceed $1 \mathrm{~mm}$ in length; it also differs by having a weaker marginal ridge only expressed along the ventral margin and thorns instead of knots marking the marginal ridge, some possibly being bifid (the lack of spines on the medio-lateral surface may relate to preservation). These differences may be related to ontogeny, Mirabairdia sp. possibly being a young instar of T. (Nodobairdia) nodata Bolz, 1971 as shown by its size. Although the ontogeny of T. (Nodobairdia) nodata Bolz, 1971 was not discussed in detail, this hypothesis might be substantiated by the precision made by Bolz (1971b: 224) that the marginal ridge is only expressed along the ventral margin on small specimens, where it is short and narrow; this corresponds to the type of ridge visible in Mirabairdia sp. Similarly, Bolz (1971b) indicates that in small specimens, the thorns are already strong and long, which is the case in Mirabairdia sp. However, the seemingly bifid nature of some thorns in Mirabairdia sp., as well as the specimen being slightly higher than specimens of the same length listed in Bolz (1971b), lead us to keep this species in open nomenclature until more material can resolve this doubt. Mirabairdia sp. can also be compared to M. longispinosa Kristan-Tollmann, 1978 from the Cordevolian, Early Carnian, Late Triassic of the Cassian Formation (Kristan-Tollmann 1978) by its much thinner lateral spines.

Genus Petasobairdia Chen in Chen \& Shi, 1982

Praelobobairdia Kozur, 1985: 66.

\section{Type species}

Petasobairdia bicornuta Chen in Chen \& Shi, 1982 by original designation.

Petasobairdia amazonella Forel sp. nov. urn:1sid:zoobank.org:act:BC1BE3CA-3515-49D8-A4A8-8EABDD0C0EE1

Figs 9Q-U, 10A-D

\section{Diagnosis}

A new species of Petasobairdia, short for the genus, triangular in outline with high anterior border.

\section{Etymology}

From A $\mu \alpha \zeta o$ $\varepsilon_{\varepsilon} /$ Amazónes, the legendary tribe of warrior women who, according to tradition, used to live along the Black Sea shore.

\section{Material examined}

\section{Holotype}

ROMANIA • 1 LV; Black Sea, Romanian Continental Shelf, borehole 817LV, sample CM31C; Rhaetian, Upper Triassic; MNHN.F.F63264. 
Paratype

ROMANIA 1 complete carapace; same locality as for holotype but sample CM31B; Rhaetian, Upper Triassic; MNHN.F.F63261.

\section{Other material}

ROMANIA - 1 complete carapace; same collection data as for holotype; Rhaetian, Upper Triassic; MNHN.F.F63259 - 1 complete carapace; same locality as for preceding but sample CM31A; Rhaetian, Upper Triassic; MNHN.F.F63260 • 1 complete carapace; same collection data as for preceding; Rhaetian, Upper Triassic; MNHN.F.F63263 - 1 complete carapace; same locality as for preceding but sample CM31B; Rhaetian, Upper Triassic; MNHN.F.F63262 4 complete carapaces, 1 RV, 1 LV; same locality as for preceding but samples CM31A, CM31B and CM31C; Rhaetian, Upper Triassic; MNHN.F.F63356.

\section{Dimensions}

See Fig. 3G.

\section{Description}

Carapace of medium size, sub-square in lateral view, with $\mathrm{H}_{\max }$ at antero-dorsal angulation and $\mathrm{L}_{\max }$ below mid-L; LV larger than RV, overlapping it slightly ventrally at ventral concavity and along dorsal margin with laterally compressed overreach along DB; dorsal margin tripartite with rounded angulations at both valves; PDB straight, steep (from $60^{\circ}$ in largest specimens to $80^{\circ}$ in smallest ones) and short (from $5 \%$ of $\mathrm{L}_{\max }$ in smallest specimens to $20 \%$ in larger forms); $\mathrm{ADB}$ and DB straight and approximately of same $\mathrm{L}\left(40-45 \%\right.$ of $\left.\mathrm{L}_{\max }\right)$; $\mathrm{ADB}$ slope of $\pm 30-40^{\circ}$; DB sloping posteriorly from $10^{\circ}$ to $15^{\circ}$; $\mathrm{AB}$ large, only poorly tapered ventrally, laterally compressed ventrally, with maximum of curvature slightly below mid-H; ventral margin long and straight with median concavity visible on some specimens; PB narrow, laterally compressed ventrally, with maximum of curvature located in lower $1 / 4$ of $\mathrm{H}_{\max }$; surface smooth; calcified inner lamella from mid-ADB to mid-PDB, relatively wide along AVB and PVB; large vestibulum along AVB and PVB, narrow in oral area; hinge bar seemingly smooth with anterior and posterior enlarged platforms; AMS field relatively compact, somewhat hastate, located below mid-H and around mid-L, composed of anteriorly incurved row of 3 individual scars and 2 to 3 scars aligned in a short posterior row (Fig. 10D).

\section{Occurrence}

Romanian Continental Shelf, Black Sea, Rhaetian, Upper Triassic (this paper).

\section{Remarks}

The laterally compressed overlap of Petasobairdia amazonella sp. nov. relates it to the Permian species P. silenitiformis (Kozur, 1985), P. nantongensis Chen, 1982 and P. subnantongensis Chen in Shi \& Chen, 1987, for instance, but its shortness, with the posterior maximum of convexity located ventrally, providing it with a sub-square outline in lateral view, differ from conditions in all known species. Although poorly preserved, the AMS pattern on the inner surface of the paratype (Fig. 10D) only differs from that of P. silenitiformis, which is to our knowledge the only observation of AMS for Petasobairdia, in being more compact and less rounded. In general terms, the outline of P. amazonella sp. nov. is reminiscent of that in Bairdia donzei Herrig, 1979 from the Domerian, Early Jurassic, of Germany (Herrig 1979a), but this Jurassic species has a longer posterior extremity and its LV is more rounded in outline and lacks the laterally compressed DB. The H/L scatter plot of all specimens of P. amazonella sp. nov. (Fig. 3G) records the occurrence of several ontogenetic stages, from A-4 to adult. The holotype (Fig. 9S-T) and paratype (Fig. 10B-D) are the largest known specimens, but owing to the size difference between the paratype and the LV of the holotype, we consider that the holotype is a submature stage. The 
development of $P$. amazonella sp. nov. is marked by the increasing height of the overlap as well as the elongation of the $\mathrm{PDB}$, from $5 \%$ of $\mathrm{L}_{\max }$ in the smallest instar to $27 \%$ in the paratype, the largest known specimen to date (Fig. 3G).

Superfamily Bairdiocypridoidea Shaver, 1961

Family Rectonariidae Gründel, 1962

\section{Remarks}

A unique isolated valve of Rectonariidae was encountered in our material. Because most of this family is characterized by asymmetrically ornamented valves, it is kept in open nomenclature. It is, however, of pivotal importance since it is the youngest report of Rectonariidae, which were abundant in deepwater environments during the Devonian-Carboniferous (e.g., Gründel 1962) with a previously last documented occurrence in the Carnian, Late Triassic, of Turkey (Forel et al. 2019a).

Rectonariidae gen. 1 in Forel et al. 2019

Fig. 10E

Rectonariidae gen. 1 - Forel et al. 2019a: 22, fig. 14c.

\section{Material examined}

ROMANIA • 1 RV; Black Sea, Romanian Continental Shelf, borehole 817LV, sample CM31C; Rhaetian, Upper Triassic; MNHN.F.F63265.

\section{Dimensions}

$\mathrm{L}=448 \mu \mathrm{m} ; \mathrm{H}=302 \mu \mathrm{m}$ ( $\mathrm{RV}$ in this paper).

$\mathrm{L}=423 \mu \mathrm{m} ; \mathrm{H}=262 \mu \mathrm{m}$ (LV in Forel et al. 2019a).

\section{Occurrence}

Kilek section, Tavusçayiri Block, Sorgun Ophiolitic Mélange, southern Turkey, Huğlu Tuffite, Tetraporobrachia haeckeli radiolarian Zone, Julian, Middle Carnian, Upper Triassic (Forel et al. 2019a); Romanian Continental Shelf, Black Sea, Rhaetian, Upper Triassic (this paper).

\section{Remarks}

Forel et al. (2019a) noted the morphological proximity of this taxon to Siciliella Crasquin et al., 2008 from the Lower-Middle Permian of Sicily (Crasquin et al. 2008), characterized by its subquadrangular outline, the occurrence of a single spine on each valve and LV overlapping RV all around. The unique LV discovered from the Carnian, Late Triassic, of Turkey was kept in open nomenclature because of the impossibility of confirming the nature of the overlap and the occurrence of a spine on each valve (Forel et al. 2019a). The present RV confirms the presence of a spine on the RV, also positioned in the posteroventral area of the valve, oriented backwards and downwards. However, until a complete carapace allows a description of the relationship between the two valves, it seems unreasonable to artificially extend the stratigraphical range of Siciliella from the Middle-Late Permian up to the Rhaetian, Late Triassic. Nevertheless, although kept in open nomenclature, Rectonariidae gen. 1 in Forel et al. 2019 confirms the occurrence of Rectonariidae during the Late Triassic that was first recorded in the Carnian of Turkey (Forel et al. 2019a). It further extends the range of Rectonariidae to the Rhaetian. 
Suborder Cypridocopina Jones, 1901

Superfamily Cypridoidea Baird, 1845

Family Paracyprididae Sars, 1923

Genus Aglaiocypris Sylvester-Bradley, 1947 sensu Kozur in Kozur et al. 1974

\section{Type species}

Aglaia pulchella Brady, 1868 subsequently designated by Sylvester-Bradley (1947).

\section{Remarks}

Aglaiocypris Sylvester-Bradley, 1947 is a recent genus and for this reason and because internal structures cannot be observed, we refer to this genus as "Aglaiocypris". Following Kozur et al. (1974), we consider that this genus may be new to science but material is still lacking to fully describe its diagnostic characters.

\section{“Aglaiocypris" sp.}

Fig. $10 \mathrm{~F}-\mathrm{G}$

\section{Material examined}

ROMANIA - 1 complete carapace; Black Sea, Romanian Continental Shelf, borehole 817LV, sample CM31A; Rhaetian, Upper Triassic; MNHN.F.F63266 • 1 complete carapace; same locality as for preceding but sample CM31C; Rhaetian, Upper Triassic; MNHN.F.F63267 • 2 complete carapaces; same locality as for preceding but sample CM31B; Rhaetian, Upper Triassic; MNHN.F.F63357.

\section{Dimensions}

$\mathrm{RV}: \mathrm{L}=333-482 \mu \mathrm{m} ; \mathrm{H}=162-243 \mu \mathrm{m} ; \mathrm{H} / \mathrm{L}=0.46-0.49$.

LV: $\mathrm{L}=333-482 \mu \mathrm{m} ; \mathrm{H}=162-243 \mu \mathrm{m} ; \mathrm{H} / \mathrm{L}=0.48-0.5$.

Fig. 10 (opposite page). SEM micrographs of ostracods from borehole 817 Lebăda Vest, drill core CM31, western portion of Black Sea shelf, Rhaetian, Late Triassic. All specimens are housed in the collections of the Muséum national d'histoire naturelle, Paris, France (MNHN). A-D. Petasobairdia amazonella Forel sp. nov. A. Right lateral view of a carapace, sample CM31A (MNHN.F.F63263). B. Holotype, external view of a left valve, sample CM31C (MNHN.F.F63264). C. Same specimen, inner view, square indicates the area enlarged in D. D. Line drawing of the adductor muscle scar field of the paratype marked in C. E. Rectonariidae gen. 1 in Forel et al. 2019, external view of a right valve, sample CM31C (MNHN.F.F63265). F-G. "Aglaiocypris" sp. F. Right lateral view of a carapace, sample CM31A (MNHN.F.F63266). G. Right lateral view of a carapace, sample CM31C (MNHN.F.F63267). H-N. Paracypris ovidi Forel sp. nov. H. Holotype, right lateral view of a carapace, sample CM31B (MNHN.F.F63268). I. Paratype 2, right lateral view of a carapace, sample CM31B (MNHN.F.F63269). J. Right lateral view of a carapace, sample CM31B (MNHN.F.F63270). K. Paratype 1, right lateral view of a carapace, sample CM31B (MNHN.F.F63271). L. Right lateral view of a carapace, sample CM31C (MNHN.F.F63272). M. Right lateral view of a carapace, sample CM31A (MNHN.F.F63273). N. Same specimen, dorsal view. O. Paracypris cf. Paracypris sp. 1 in Lord \& Lambourne 1991, right lateral view of a carapace, sample CM31A (MNHN.F.F63274). P-Q. Paracypris sp. 1. P. Right lateral view of a carapace, sample CM31B (MNHN.F.F63275). Q. Right lateral view of a carapace, sample CM31C (MNHN.F.F63276). R-U. Paracypris sp. 2. R. Right lateral view of a carapace, sample CM31B (MNHN.F.F63277). S. Right lateral view of a carapace, sample CM31C (MNHN.F.F63278). T. Right lateral view of a carapace, sample CM31A (MNHN.F.F63279). U. Right lateral view of a carapace, sample CM31B (MNHN.F.F63280). Scale bars: $100 \mu \mathrm{m}$. 


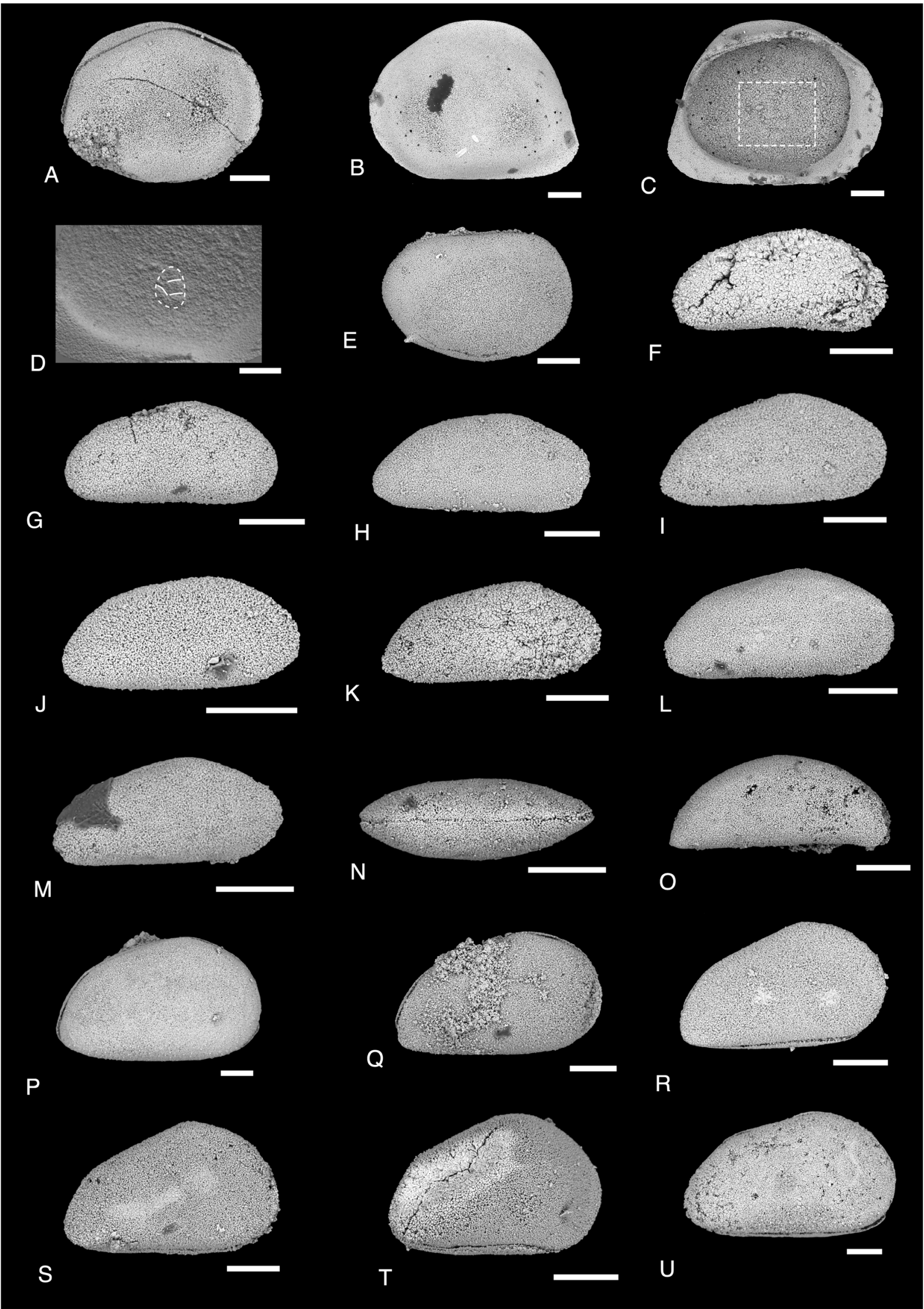




\section{Occurrence}

Romanian Continental Shelf, Black Sea, Rhaetian, Upper Triassic (this paper).

\section{Remarks}

The present species is close to Aglaiocypris? sp. from the Ladinian, Middle Triassic, of Spain (Kozur et al. 1974). This species is morphologically similar to Fabalicypris? sp. A in Ainsworth 1990 from the Hettangian, Early Jurassic, from Ireland (Ainsworth 1990), but the carapace of the present species is thinner, with $\mathrm{H}_{\max }$ located more anteriorly, shorter and more rounded $\mathrm{ADB}$, and $\mathrm{AB}$ more rounded and less bairdiid. These characters are closer to those of Aglaiocypris as described in Kozur et al. (1974).

Genus Paracypris Sars, 1866

\section{Type species}

Paracypris polita Sars, 1866 by original designation.

Paracypris ovidi Forel sp. nov.

urn:lsid:zoobank.org:act:7DB2FA3F-A4F7-451A-ACC2-5D3D6199CADD

Fig. $10 \mathrm{H}-\mathrm{N}$

\section{Diagnosis}

A small ear-shaped species with conspicuous dorsal angulations and anterior maximum of curvature slightly below mid-height.

\section{Etymology}

In reference to the Latin poet Ovid (Publius Ovidius Naso) who died in exile on the Black Sea shore in Tomis, present-day Constanţa (Romania).

\section{Material examined}

\section{Holotype}

ROMANIA 1 complete carapace; Black Sea, Romanian Continental Shelf, borehole 817LV, sample CM31B; Rhaetian, Upper Triassic; MNHN.F.F63268.

\section{Paratypes}

ROMANIA - 1 complete carapace; same collection data as for holotype; Rhaetian, Upper Triassic; MNHN.F.F63271 • 1 complete carapace; same collection data as for holotype; Rhaetian, Upper Triassic; MNHN.F.F63269.

\section{Other material}

ROMANIA - 1 complete carapace; same collection data as for holotype; Rhaetian, Upper Triassic; MNHN.F.F63270 • 1 complete carapace; same collection data as for holotype; Rhaetian, Upper Triassic; MNHN.F.F63364 1 complete carapace; same locality as for preceding but sample CM31C; Rhaetian, Upper Triassic; MNHN.F.F63272 - 1 complete carapace; same locality as for preceding but sample CM31A; Rhaetian, Upper Triassic; MNHN.F.F63273 - 11 complete carapaces, 2 broken carapaces; same locality as for preceding but samples CM31A, CM31B and CM31C; Rhaetian, Upper Triassic; MNHN.F.F63358.

\section{Dimensions}

See Fig. 3H. 


\section{Description}

Carapace small, ear-shaped, tapered posteriorly in lateral view, with $\mathrm{H}_{\max }$ at antero-dorsal angulation, $\mathrm{L}_{\max }$ slightly below mid- $\mathrm{H}$ and $\mathrm{W}_{\max }$ at mid-L; LV overlaps $\mathrm{RV}$ very thinly along DB, PDB and VB; dorsal margin distinctly tripartite with conspicuous angulations, more uniformly arched in small specimens; ADB, DB and PDB straight, PDB sometimes slightly convex; ADB and DB of similar length $( \pm 80 \%$ of $\mathrm{L}_{\max }$ ), respectively gently sloping to $\mathrm{AB}$ and antero-dorsal angulation; $\mathrm{PB} \operatorname{short}\left( \pm 20 \%\right.$ of $\left.\mathrm{L}_{\max }\right)$, inclined posteriorly with an angle of $45-55^{\circ}$; $\mathrm{AB}$ relatively large, with largely rounded AVB and maximum of convexity located slightly below mid-H; PB narrowly rounded, with maximum of curvature slightly above ventral margin; surface smooth; inner structures not visible.

\section{Occurrence}

Romanian Continental Shelf, Black Sea, Rhaetian, Upper Triassic (this paper).

\section{Remarks}

Paracypris ovidi sp. nov. is closely related to Pseudomacrocypris? kerabani sp. nov. described below, from which it differs by having dorsal angulations more acute and $\mathrm{AB}$ angulation located slightly higher. Paracypris ovidi sp. nov. also displays a normal overlap of LV around RV, which excludes it from Pseudomacrocypris and relates it to Paracypris. Paracypris ovidi sp. nov. also differs from the widespread Jurassic P. redcarensis (Blake, 1876) (e.g., Harloff \& Jäger 1994; Boomer et al. 1998; Ainsworth \& Boomer 2001; Honigstein et al. 2014) in being less tapered posteriorly, with a less rounded anterior margin and a less pronounced overlap.

The $\mathrm{H} / \mathrm{L}$ diagram shown in Fig. $3 \mathrm{H}$ documents the occurrence of several ontogenetic stages, the delimitation of which is complicated. The holotype (Fig. 10H) and one of the paratypes (Fig. 10I) are among the largest specimens recorded. The ontogenetic development of Paracypris ovidi sp. nov. mainly consists in size increase and accentuation of dorsal angulations.

Paracypris cf. Paracypris sp. 1 in Lord \& Lambourne 1991

Fig. 100

\section{Material examined}

ROMANIA 1 complete carapace; Black Sea, Romanian Continental Shelf, borehole 817LV, sample CM31A; Rhaetian, Upper Triassic; MNHN.F.F63274.

\section{Dimensions}

$\mathrm{L}=404 \mu \mathrm{m} ; \mathrm{H}=135 \mu \mathrm{m} ; \mathrm{H} / \mathrm{L}=0.41$.

\section{Occurrence}

Romanian Continental Shelf, Black Sea, Rhaetian, Upper Triassic (this paper).

\section{Remarks}

The present species shares very close morphological proximity with Paracypris sp. 1 in Lord \& Lambourne 1991 from the Pliensbachian, Early Jurassic, of the Western Pontides, Turkey (Lord \& Lambourne 1991): similar H/L ratio (0.41), low anterior maximum of curvature pointing downward, pointed $\mathrm{PB}$ at venter, oral concavity long, poorly expressed, located in anterior half of $\mathrm{L}_{\max }$. The two specimens might be conspecific, but the Rhaetian specimen is smaller than the Jurassic one $(\mathrm{L}=700 \mu \mathrm{m}$; 
$\mathrm{H}=289 \mu \mathrm{m})$ and might represent an immature stage. These two hypotheses can only be tested by more sampling in the two areas.

Family Pontocyprididae Müller, 1894

Genus Pseudomacrocypris Michelsen, 1975

\section{Type species}

Pseudomacrocypris subtriangularis Michelsen, 1975 by original designation.

\section{Remarks}

Pseudomacrocypris Michelsen, 1975 was described from the Jurassic of Denmark (Michelsen 1975). Michelsen (1975) referred to the tripartite hinge of Pseudomacrocypris as "markedly dentate" and therefore referred this genus to the Macrocyprididae Sars, 1866. However, Maddocks (1991) showed that the hinge structure is convergent with that of Macrocyprididae while other features are typical of Pontocyprididae Sars, 1866. We here follow this revision and consider Pseudomacrocypris as part of the Pontocyprididae.

\section{Pseudomacrocypris? kerabani Forel sp. nov. urn:1sid:zoobank.org:act:57649028-73AB-43AE-B320-0FE94576E4C3}

Fig. 11B-G

Pontocypris? sp. pars - Kristan-Tollmann et al. 1991a: 165, pl. 2, fig. 11.

Pontocypris? sp. - Mette \& Mohtat-Aghai 1999: 53, pl. 2, fig. 8.

non Pontocypris? sp. - Kristan-Tollmann et al. 1991a: 165, pl. 7, fig. 5.

\section{Diagnosis}

A species with truncate subtriangular outline, with low anterior and posterior maximum of curvature and offset overlap along dorsal and ventral borders.

\section{Etymology}

From the novel Kéraban-le-Têtu, by Jules Verne, that describes the adventures of a Turkish tobacco seller, Kéraban, around the Black Sea.

\section{Material examined}

\section{Holotype}

ROMANIA - 1 complete carapace; Black Sea, Romanian Continental Shelf, borehole 817LV, sample CM31C; Rhaetian, Upper Triassic; MNHN.F.F63283.

\section{Paratype}

ROMANIA - 1 complete carapace; same collection data as for holotype; Rhaetian, Upper Triassic; MNHN.F.F63282.

\section{Other material}

ROMANIA - 1 complete carapace; same collection data as for holotype; Rhaetian, Upper Triassic; MNHN.F.F63284 • 1 complete carapace; same collection data as for holotype; Rhaetian, Upper Triassic; MNHN.F.F63285 • 1 complete carapace; same collection data as for holotype; Rhaetian, Upper Triassic; MNHN.F.F63287 - 1 complete carapace; same locality as for preceding but sample CM31B; Rhaetian, Upper Triassic; MNHN.F.F63286 - 9 complete carapaces, 2 broken carapaces; same locality as for preceding but samples CM31A, CM31B and CM31C; Rhaetian, Upper Triassic; MNHN.F.F63359. 


\section{Dimensions}

Fig. 4A.

\section{Description}

Carapace of medium size, dorsally-truncate subtriangular in lateral view, with $\mathrm{H}_{\max }$ at antero-dorsal angulation, $\mathrm{L}_{\max }$ around lower $1 / 4$ of $\mathrm{H}_{\max }$; offset overlap characterized by LV overlaping RV along DB (e.g., Fig. 11B) and RV overlaping LV along VB (Fig. 11E); dorsal margin divided into three parts of similar length, with blunt antero-dorsal and postero-dorsal angulations, the latter poorly expressed in smooth juveniles; ADB gently arched inclined anteriorly with an angle of $30-35^{\circ}$, DB straight, slightly inclined toward PD angulation, thinly overlapped by LV at RV, PDB straight to very tenuously convex in small specimens, bent posteriorly with an angle of $\pm 40^{\circ}$; $\mathrm{AB}$ at the same level or slightly above $\mathrm{PB}$, uniformly rounded, with relatively narrow curvature; PB narrow, rounded to bluntly angulate, with maximum close to ventral margin; ventral margin long and gently convex, with thin overlap of RV on LV in center and shallow concavity anteriorly in some specimens (e.g., Fig. 11C, G); surface smooth; inner structures not visible.

\section{Occurrence}

Kössen Formation, Northern Calcareous Alps, Tyrol, Austria, Rhaetian, Upper Triassic (KristanTollmann et al. 1991a; Mette \& Mohtat-Aghai 1999); Romanian Continental Shelf, Black Sea, Rhaetian, Upper Triassic (this paper).

\section{Remarks}

Pseudomacrocypris? kerabani sp. nov. has previously been pictured from the Kössen Formation outcropping in Tyrol (Kristan-Tollmann et al. 1991a; Mette \& Mohtat-Aghai 1999), where it was attributed with doubt to the genus Pontocypris Sars, 1866. One of the two specimens from the Rhaetian of Austria shown in Kristan-Tollmann et al. (1991a; pl. 7, fig. 5) is excluded because of its lateral outline and much larger dimensions. Pseudomacrocypris Michelsen, 1975 is characterized by a right over left valve overlap and a central adductorial muscle field of rosette shape made of 5-6 spots (Michelsen 1975; Kaye 1965; Maddocks 1991). Although the dentate and tripartite hinge of Pseudomacrocypris is unusual for Pontocyprididae (Maddocks 1991), the muscle-scar pattern as well as the nature of the overlap led Maddocks (1991) to consider that Pseudomacrocypris and Propontocypris might be synonymous, and re-attributed Pseudomacrocypris to the family Pontocyprididae. Maddocks (1991: 41) summarized the common characters between Pseudomacrocypris and Propontocypris as follows: laterally compressed carapace, subtriangular to subovate in lateral view, tiny size ( $\mathrm{L}=0.41 \mathrm{~mm})$, smooth exterior with numerous tiny normal pore canals, right valve overlap, straight dorsal valve-contact line and deep vestibules. However, Pseudomacrocypris is kept as a separate genus because of its unusual hinge and age (Early Jurassic to Early Cretaceous in Maddocks 1991). Only complete carapaces have been found in the present analysis, which unfortunately precludes the close observation of hinge and AMS patterns. However, the offset overlap of RV over LV along the ventral margin and LV over RV along DB is unusual for both genera, but Pseudomacrocypris is preferred here because of the age and presence of right over left valve overlap, although partial. Pseudomacrocypris? kerabani sp. nov. differs from $P$. cf. subtriangularis Michelsen, 1975 in Kristan-Tollmann et al. 1991 from the Rhaetian of Tyrol (Kristan-Tollmann et al. 1991a) in being more slender, with narrower AB, less pointed PB and RV overlapping LV only along VB. It also differs from Pseudomacrocypris sp. from the same level by having a less rounded $\mathrm{ADB}$ and narrower $\mathrm{AB}$ with the maximum of curvature located more ventrally. Pseudomacrocypris? kerabani sp. nov. also differs from the widespread Jurassic P. subtriangularis (e.g., Sivhed 1980; Harloff \& Jäger 1994; Boomer et al. 1998; Cabral et al. 2013) by having its AB located more ventrally and LV overlapping RV along DB. 
The H/L diagram of all specimens shown in Fig. 4A documents the occurrence of at least 4 ontogenetic stages, from A-3 to adult. It is noteworthy that the specimen shown in Kristan-Tollmann et al. (1991a) is much larger than all others, including those from the same locality reported by Mette \& Mohtat-Aghai (1999). The holotype may be an adult (Fig. 11C), with a quite large dispersal of size in adult specimens, while the paratype (Fig. 11B) is an A-1 instar. The lateral morphology of Pseudomacrocypris? kerabani sp. nov. is very conservative through its development, only marked by a slight enlargement of the posterior maximum of convexity and an accentuation of the tripartite division of the dorsal margin.

Suborder Cytherocopina Gründel, 1967
Superfamily Cytheroidea Baird, 1850

Family Cytheruridae Müller, 1894

\section{Remarks}

The classification of Triassic and Early Jurassic Cytheruridae was revised by Whatley \& Boomer (2000), who considered that they are distributed in two subfamilies: Cytheropterinae Hanai, 1957 and Cytherurinae Müller, 1894. Conversely, Maddocks \& Steineck (1987) and Mazzini \& Gliozzi (2000) proposed a three subfamily arrangement for the Cytheruridae: Cytheropterinae Hanai, 1957, Cytherurinae Müller, 1894 and Eucytherurinae Puri, 1974 (emend. Maddocks \& Steineck 1987). The recent phylogenetic analysis carried on the living Eucytherurinae Xylocythere sarrazinae Tanaka \& Hayashi, 2019 from a hydrothermal vent field in the northeastern Pacific Ocean, supports the three subfamily scheme (Tanaka \& Hayashi 2019). This molecular analysis furthermore highlights the basal position of Xylocythere sarrazinae, supporting the hypothesis of an ancient origin of Eucytherurinae. In their revision, Whatley \& Boomer (2000) considered a number of Early Mesozoic Cytheruridae as junior synonyms of the extant genus Eucytherura Müller, 1894 and classified this genus within the Cytherurinae, in line with contributions on extent Cytheruridae (e.g., Ayress et al. 1995; Ballent \& Whatley 2009).

Fig. 11 (opposite page). SEM micrographs of ostracods from borehole 817 Lebăda Vest, drill core CM31, western portion of Black Sea shelf, Rhaetian, Late Triassic. All specimens are housed in the collections of the Muséum national d'histoire naturelle, Paris, France (MNHN). A. Paracypris sp. 3, right lateral view of a carapace, sample CM31A (MNHN.F.F63281). B-G. Pseudomacrocypris? kerabani Forel sp. nov. B. Paratype, right lateral view of a carapace, sample CM31C (MNHN.F.F63282). C. Holotype, right lateral view of a carapace, sample CM31C (MNHN.F.F63283). D. Right lateral view of a carapace, sample CM31C (MNHN.F.F63284). E. Left lateral view of a carapace, sample CM31C (MNHN.F.F63285). F. Right lateral view of a carapace, sample CM31B (MNHN.F.F63286). G. Right lateral view of a carapace, sample CM31C (MNHN.F.F63287). H. Pseudomacrocypris? sp., left lateral view of a carapace, sample CM31B (MNHN.F.F63288). I-J. Praebythoceratina sp. I. Right lateral view of a carapace, sample CM31B (MNHN.F.F63289). J. Same specimen, dorsal view. K. Triassocythere sp., external view of a left valve, sample CM31C (MNHN.F.F63290). L-M. Judahella andrusovi Kozur \& Bolz in Bunza \& Kozur, 1971. L. Right lateral view of a carapace, sample CM31C (MNHN.F.F63291). M. External view of a right valve, sample CM31A (MNHN.F.F63292). N-P. Cytheruridae gen. et sp. indet. N. Right lateral view of a carapace, sample CM31C (MNHN.F.F63293). O. Right lateral view of a carapace, sample CM31C (MNHN.F.F63294). P. Right lateral view of a carapace, sample CM31C (MNHN.F.F63295). Q. Praemacrocypris sp., external view of a right valve, sample CM31B (MNHN.F.F63296). R-S. Cardobairdia sp. 1. R. Right lateral view of a carapace, sample CM31B (MNHN.F.F63297). S. Right lateral view of a carapace, sample CM31A (MNHN.F.F63298). T-U. Cardobairdia sp. 2. T. Right lateral view of a carapace, sample CM31A (MNHN.F.F63299). U. Right lateral view of a carapace, sample CM31B (MNHN.F.F63300). Scale bars: $100 \mu \mathrm{m}$. 


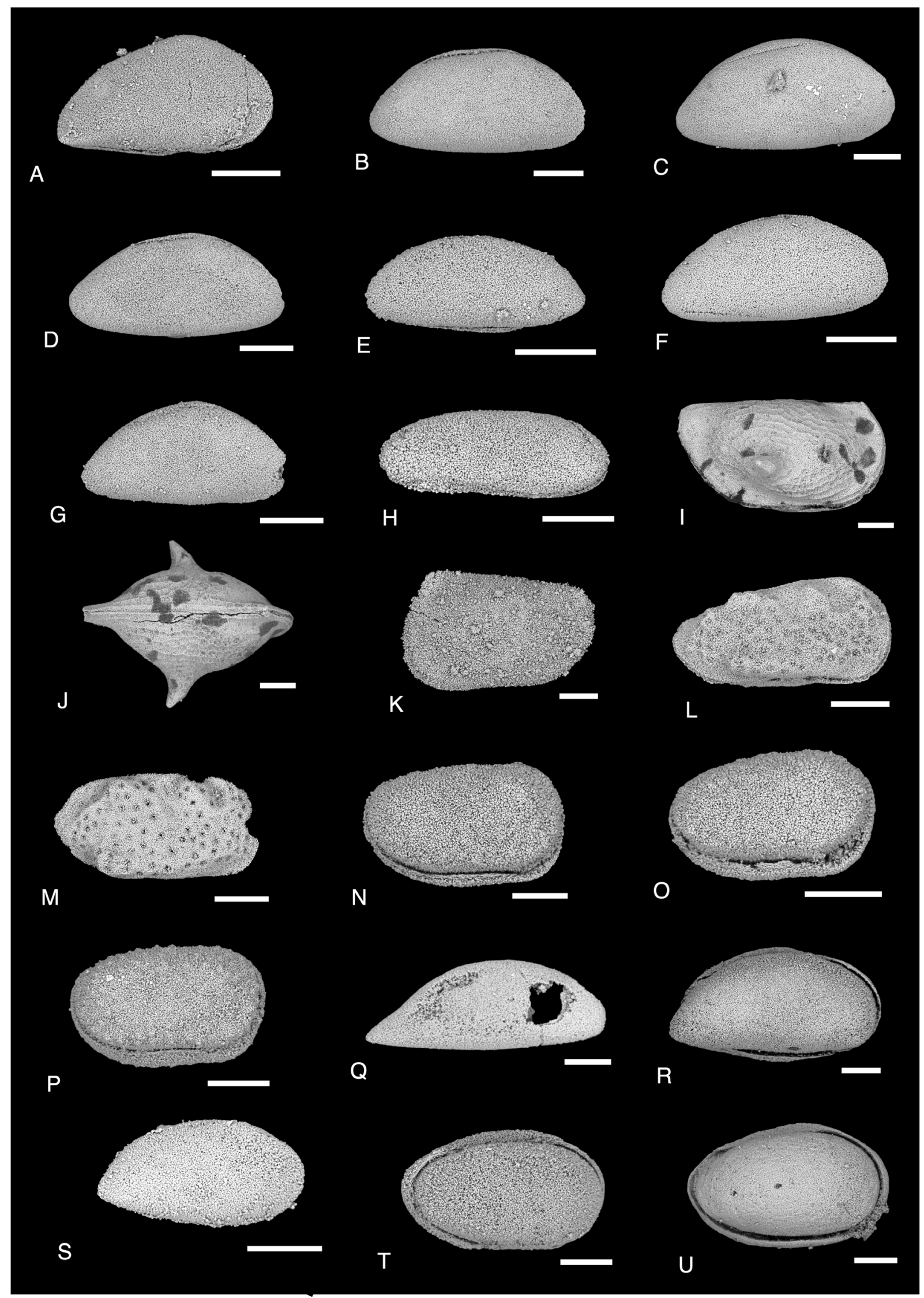


Subfamily Cytherurinae Müller, 1894

Genus Judahella Sohn, 1968

\section{Type species}

Judahella tsorfatia Sohn, 1968 by original designation.

Judahella andrusovi Kozur \& Bolz in Bunza \& Kozur, 1971

Fig. 11L-M

Judahella andrusovi Kozur \& Bolz in Bunza \& Kozur 1971: 25, pl. 14, figs 14, 16-22.

Judahella andrusovi - Kozur 1972: pl. 2, fig. 9. — Urlichs 1972: 679, pl. 1, fig. 15. — Kristan-Tollmann et al. 1991a: 202, pl. 2, fig. 8, pl. 5, figs 1-7; 1991b: pl. 3, figs 10-11. — Mette et al. 2012: 70. — Forel et al. 2019a: 26-27, fig. 18e-h.

Judahella (Judahella) andrusovi - Kristan-Tollmann et al. 1980: 189, pl. 11, figs 9-10. — KristanTollmann 1983: 151, pl. 9, figs 5-9; 1988: figs 6, 12.

\section{Material examined}

ROMANIA 1 complete carapace; Black Sea, Romanian Continental Shelf, borehole 817LV, sample CM31C; Rhaetian, Upper Triassic; MNHN.F.F63291 • 1 RV; same locality as for preceding but sample CM31A; Rhaetian, Upper Triassic; MNHN.F.F63292 1 complete carapace, 1 RV; same locality as for preceding but samples CM31B and CM31C; Rhaetian, Upper Triassic; MNHN.F.F63360.

\section{Dimensions}

Females (only RV; Fig. 11M): $\mathrm{L}=371-468 \mu \mathrm{m} ; \mathrm{H}=196-264 \mu \mathrm{m}$.

Males (one carapace measured; Fig 11L): LV: $\mathrm{L}=508 \mu \mathrm{m} ; \mathrm{H}=251 \mu \mathrm{m} . \mathrm{RV}: \mathrm{L}=502 \mu \mathrm{m} ; \mathrm{H}=244 \mu \mathrm{m}$.

\section{Occurrence}

Leidapo section, South China, upper Anisian, Middle Triassic (Kristan-Tollmann 1983); Transdanubian Central Range, Hungary, Carnian, Upper Triassic (Kristan-Tollmann et al. 1991b); Hungary, upper Norian, Upper Triassic (Kozur 1972); Ampelsbach, Austria, upper Norian, Upper Triassic (Bunza \& Kozur 1971); Saltspring section, Bagerabad, Iran, Rhaetian, Upper Triassic (Kristan-Tollmann et al. 1980; Kristan-Tollmann 1988); Austria, Rhaetian, Upper Triassic (Urlichs 1972; Kristan-Tollmann et al. 1991b; Mette et al. 2012); Kilek section, Mersin Mélange, southern Turkey, Huğlu Tuffite, Julian, middle Carnian, Upper Triassic (Forel et al. 2019a); Romanian Continental Shelf, Black Sea, Rhaetian, Upper Triassic (this paper).

Cytheruridae gen. et sp. indet.

Fig. $11 \mathrm{~N}-\mathrm{P}$

\section{Material examined}

ROMANIA • 1 complete carapace; Black Sea, Romanian Continental Shelf, borehole 817LV, sample CM31C; Rhaetian, Upper Triassic; MNHN.F.F63293 • 1 complete carapace; same collection data as for preceding; Rhaetian, Upper Triassic; MNHN.F.F63294 • 1 complete carapace; same collection data as for preceding; Rhaetian, Upper Triassic; MNHN.F.F63295 • 1 complete carapace; same locality as for preceding but sample CM31B; Rhaetian, Upper Triassic; MNHN.F.F63361. 


\section{Dimensions}

RV: $\mathrm{L}=256-319 \mu \mathrm{m} ; \mathrm{H}=170-197 \mu \mathrm{m} ; \mathrm{H} / \mathrm{L}=0.6-0.63$.

$\mathrm{LV}: \mathrm{L}=271-301 \mu \mathrm{m} ; \mathrm{H}=145-172 \mu \mathrm{m} ; \mathrm{H} / \mathrm{L}=0.57$.

\section{Occurrence}

Romanian Continental Shelf, Black Sea, Rhaetian, Upper Triassic (this paper).

\section{Remarks}

These very small specimens are characterized by a strong overlap of LV around the free margin of RV, lateral surface of both valves entirely tuberculate, lack of marginal compression, and a lack of caudal process, sulcus or lateral extensions. They may correspond to a new genus but the material is still too scant to confirm this hypothesis and fully appreciate the diagnostic characters of this possibly new genus.

Superfamily Sigillioidea Mandelstam, 1960

Family Sigilliidae Mandelstam, 1960

Genus Cardobairdia van den Bold, 1960 emend. McKenzie 1967

\section{Type species}

Cardobairdia ovata van den Bold, 1960 by original designation.

\section{Cardobairdia sp. 3}

Fig. 12D-F

\section{Material examined}

ROMANIA - 1 complete carapace; Black Sea, Romanian Continental Shelf, borehole 817LV, sample CM31C; Rhaetian, Upper Triassic; MNHN.F.F63302 • 1 RV; same collection data as for preceding; Rhaetian, Upper Triassic; MNHN.F.F63362 1 complete carapace; same locality as for preceding but sample CM31A; Rhaetian, Upper Triassic; MNHN.F.F63303.

\section{Dimensions}

RV: $\mathrm{L}=275-354 \mu \mathrm{m} ; \mathrm{H}=143-203 \mu \mathrm{m} ; \mathrm{H} / \mathrm{L}=0.59-0.64$.

LV: $\mathrm{L}=283-299 \mu \mathrm{m} ; \mathrm{H}=168-192 \mu \mathrm{m} ; \mathrm{H} / \mathrm{L}=0.52-0.59$.

\section{Occurrence}

Romanian Continental Shelf, Black Sea, Rhaetian, Upper Triassic (this paper).

\section{Remarks}

Cardobairdia sp. 3 is very close to Cardobairdia cf. liassica (Drexler, 1958) in Monostori 2008 from the Pliensbachian of Hungary (Monostori 2008: pl. 1, fig. 8). Cardobairdia has been attributed to the Sigilliidae, which are merodont hinge ostracods (e.g., Tabuki \& Hanai 1999; Olempska 2001). Cardobairdia shows a crenulate posterior tooth, which might correspond to a merodont hingement. However, the ventral bar is not visible, so it is not possible to assess with certainty that it is crenulate or whether the lobes occur before and after the anterior and posterior teeth. 
Suborder Metacopina Sylvester-Bradley, 1961

Superfamily Healdioidea Harlton, 1933

Family Healdiidae Harlton, 1933

Genus Hungarella Méhes, 1911

\section{Type species}

Hungarella problematica Méhes, 1911 by original designation.

\section{Remarks}

The possible synonymy of Ogmoconcha, described from the Lias $\delta$ of Germany (Triebel 1941), and Hungarella, described from the Triassic of Hungary (Méhes 1911), has long been debated but material from the type locality of Hungarella has yet to be observed to clarify this issue (e.g., Lord 1972, 1982). Here we agree with the position of Lord who stated that "it is preferable to call Lower Jurassic species which are congeneric with Ogmoconcha contractula Triebel, 1941 (type species of Ogmoconcha) by the generic name Ogmoconcha rather than Hungarella since the synonymy of the two genera is unproved" (Lord 1972: 332), and consider that the corollary position should be applied by restricting the use of Hungarella to Triassic species. Until the relationship of Ogmoconcha and Hungarella is clarified, we choose to only use Hungarella for Triassic species to avoid artificially rooting Ogmoconcha down to the Triassic and biasing our understanding of the diversity dynamics at the end of the Triassic (Forel \& Crasquin 2020). We thus follow Kristan-Tollmann (1977a, 1977b) and Lord (1982) in considering that:

- the valves of Hungarella are asymmetrical contrary to those of Ogmoconcha

- the anterior margin of the RV of Hungarella may display a rim or a spine but numerous marginal spines are diagnostic of Ogmoconcha

Fig. 12 (opposite page). SEM micrographs of ostracods from borehole 817 Lebăda Vest, drill core CM31, western portion of Black Sea shelf, Rhaetian, Late Triassic. All specimens are housed in the collections of the Muséum national d'histoire naturelle, Paris, France (MNHN). A-C. Cardobairdia sp. 2. A. Same specimen as in Fig. 11U (MNHN.F.F63300), dorsal view. B. Right lateral view of a carapace, sample CM31C (MNHN.F.F63301). C. Same specimen, dorsal view. D-F. Cardobairdia sp. 3. D. Right lateral view of a carapace, sample CM31C (MNHN.F.F63302). E. Details of posterior end of hingement of specimen shown in F. F. Right lateral view of a carapace, sample CM31A (MNHN.F.F63303). G-K. Cardobairdia sp. 4. G. Right lateral view of a carapace, sample CM31A (MNHN.F.F63304). H. Right lateral view of a carapace, sample CM31B (MNHN.F.F63305). I. Same specimen, dorsal view. J. Right lateral view of a carapace, sample CM31B (MNHN.F.F63306). K. Same specimen, dorsal view. L. Cardobairdia sp. 5, external view of a left valve, sample CM31C (MNHN.F.F63307). M. Cardobairdia? sp. 6, right lateral view of a carapace, sample CM31B (MNHN.F.F63308). N-Q. Hungarella koessenensis (Mette \& Mohtat-Aghai, 1999). N. Right lateral view of a carapace, sample CM31B (MNHN.F.F63309). O. External view of a left valve, sample CM31B (MNHN.F.F63310). P. Inner view of a left valve, sample CM31B (MNHN.F.F63311). Q. External view of a right valve, sample CM31B (MNHN.F.F63312). R. Hungarella sp. 1, external view of a right valve, sample CM31B (MNHN.F.F63313). S. Hungarella? sp. 2, right lateral view of a carapace, sample CM31C (MNHN.F.F63314). T. Cytherelloidea cf. modesta Apostolescu, 1959, external view of a left valve, sample CM31B (MNHN.F.F63315). U. Cytherelloidea? sp., external view of a right valve, sample CM31A (MNHN.F.F63316). Scale bars: $100 \mu \mathrm{m}$. 


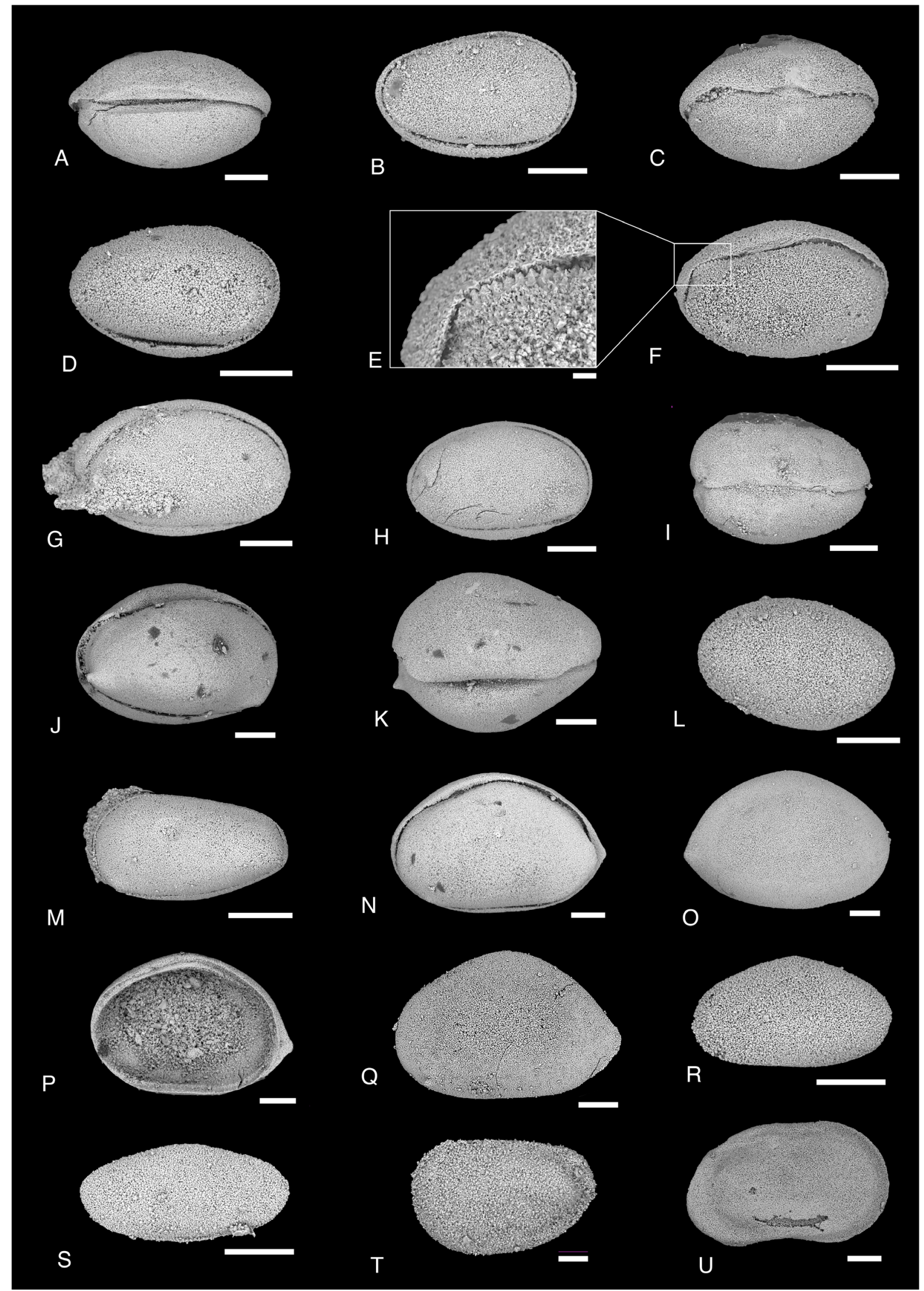


Hungarella koessenensis (Mette \& Mohtat-Aghai, 1999)

Fig. $12 \mathrm{~N}-\mathrm{Q}$

Ogmoconcha koessenensis Mette \& Mohtat-Aghai, 1999: 52-53, pl. 2, figs 1-4.

? Ogmoconcha sp. - Sohn 1987: C18, pl. 10, figs 12-14, pl. 11, figs 13-16, $20-24$.

\section{Material examined}

ROMANIA 1 complete carapace; Black Sea, Romanian Continental Shelf, borehole 817LV, sample CM31B; Rhaetian, Upper Triassic; MNHN.F.F63309 • $1 \mathrm{LV}$; same collection data as for preceding; Rhaetian, Upper Triassic; MNHN.F.F63310 - 1 LV; same collection data as for preceding; Rhaetian, Upper Triassic; MNHN.F.F63311 - $1 \mathrm{RV}$; same collection data as for preceding; Rhaetian, Upper Triassic; MNHN.F.F63312 3 complete carapaces, 14 LV, 8 RV; same locality as for preceding but samples CM31A, CM31B and CM31C; Rhaetian, Upper Triassic; MNHN.F.F63363.

\section{Occurrence}

Eiberg Member, upper Kössen Formation, Waidringer Setinplatte, Northern Calcareous Alps, Tyrol, Austria, upper Rhaetian, Upper Triassic (Mette \& Mohtat-Aghai 1999); Romanian Continental Shelf, Black Sea, Rhaetian, Upper Triassic (this paper).

\section{Dimensions}

Fig. 4B.

\section{Remarks}

This species was ascribed to Ogmoconcha Triebel, 1941 by Mette \& Mohtat-Aghai (1999) and it is here re-attributed to Hungarella as explained above. Mette \& Mohtat-Aghai (1999) noted the closeness of H. koessenensis to Hungarella sp. from the Carnian of Hungary (identified as Ogmoconcha sp. in Sohn 1987) but could not confirm their conspecificity because of low preservation and low abundance of their material. In spite of the relatively good preservation of the present material, apart from the inner structures, the illustrations of Ogmoconcha sp. in Sohn 1987 do not allow us to ascertain the conspecificity of the specimens.

The dimensions of all known valves and carapaces are shown in Fig. 4B, where LV and RV are distinguished. The delimitation of successive ontogenetic stages is here hardened by the relatively important overlap of LV over RV, resulting in the overlap of their distributions on the H/L diagram (Fig. 4B). The three carapaces known (e.g., Fig. 12N) serve as anchor-points and appear to document a relative increase in the thickness of the overlap through the ontogeny of Hungarella koessenensis. The $\mathrm{H} / \mathrm{L}$ diagram furthermore documents two distinct groups of valves that are not visible in the smallest specimens: a first group of small valves and a second group of larger valves, the three carapaces belonging to the first one. These two groups may represent sexually dimorphic specimens, the larger ones being wider posteriorly, with PB close to vertical, and possibly related to females. Such a pattern of size and morphology has also been observed for H. subtera Zheng, 1976 from the Carnian of South China (Forel et al. 2019b). Owing to these observations, we consider that six ontogenetic stages, A-5 to adult, occur for H. koessenensis (Fig. 4B). A-5 is represented by a unique RV while A-3 is represented by only two LV. The ontogeny of this species appear to be mainly related to size increase and the apparition of sexual dimorphism in A-3. 
Subclass Myodocopa Sars, 1866

Order Halocyprida Dana, 1853

Suborder Halocypridina Dana, 1853

Superfamily Thaumatocypridoidea Müller, 1906

Family Thaumatocyprididae Müller, 1906

Genus Pokornyopsis Kozur, 1974

\section{Type species}

Thaumatocypris feifeli Triebel, 1941 subsequently designated by Kozur (1974).

\section{Pokornyopsis sp. 1}

Fig. 13B-C

\section{Material examined}

ROMANIA 1 complete carapace; Black Sea, Romanian Continental Shelf, borehole 817LV, sample CM31B; Rhaetian, Upper Triassic; MNHN.F.F63318.

\section{Dimensions}

$\mathrm{L}=618 \mu \mathrm{m} ; \mathrm{H}=494 \mu \mathrm{m}$.

\section{Occurrence}

Romanian Continental Shelf, Black Sea, Rhaetian, Upper Triassic (this paper).

\section{Remarks}

Pokornyopsis feifeli (Triebel, 1941) from the Early to Late Jurassic (see Tóth \& Cséfán 2018 for a summary) is characterized by having strongly reticulate valves with parallel ribs surrounded by 3 concentric marginal ribs. Pokornyopsis sp. 1 has less numerous and more spaced parallel ribs on the lateral surface. The three marginal ribs of $P$. feifeli are here lacking, a strong thin ridge runs parallel to the free margin, the rostrum is more pronounced, and the incisure is deeper and narrower.

\section{Pokornyopsis? sp. 2}

Fig. 13D-E

\section{Material examined}

ROMANIA 1 complete carapace; Black Sea, Romanian Continental Shelf, borehole 817LV, sample CM31A; Rhaetian, Upper Triassic; MNHN.F.F63319 • 1 complete carapace; same collection data as for preceding; Rhaetian, Upper Triassic; MNHN.F.F63320.

\section{Dimensions}

LV (Fig. 13D): $\mathrm{L}=289 \mu \mathrm{m} ; \mathrm{H}=258 \mu \mathrm{m}$.

RV (Fig. 13E): $\mathrm{L}=228 \mu \mathrm{m} ; \mathrm{H}=203 \mu \mathrm{m}$.

\section{Occurrence}

Romanian Continental Shelf, Black Sea, Rhaetian, Upper Triassic (this paper).

\section{Remarks}

Pokornyopsis? sp. 2 is close to Polycope? or Thaumatocypris? sp. from the Jurassic of Tethys (Oertli 1972: pl. 3, figs 39-42) in having a sharp and pointed outline of the rostrum. However, the ornamentation 
of the present specimen is much stronger than in the Jurassic material. Furthermore, a postero-dorsal nodule is apparently present and relates the present specimen to the genus Pokornyopsis, which is not reported in Oertli (1972).

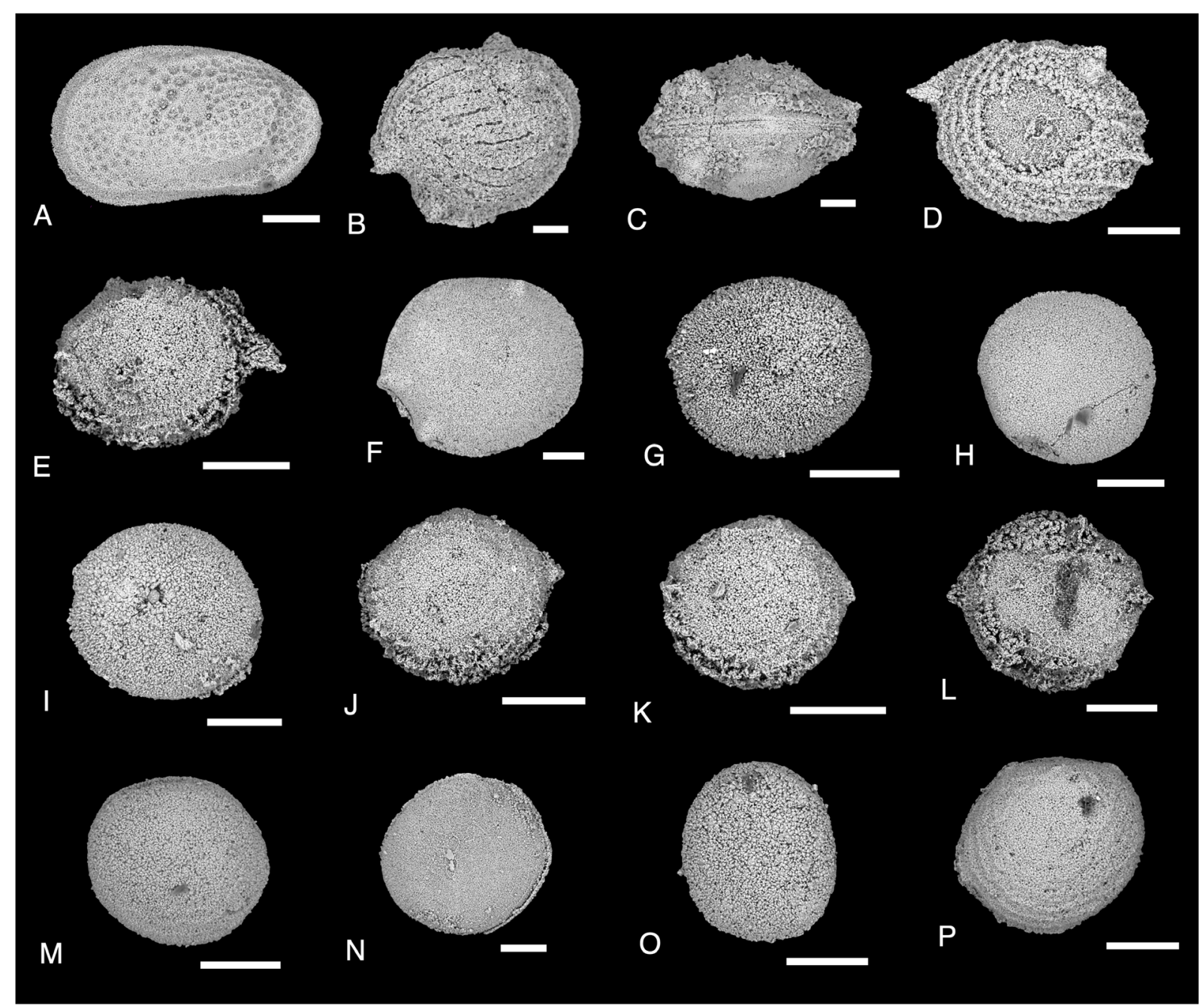

Fig. 13. SEM micrographs of ostracods from borehole 817 Lebăda Vest, drill core CM31, western portion of Black Sea shelf, Rhaetian, Late Triassic. All specimens are housed in the collections of the Muséum national d'histoire naturelle, Paris, France (MNHN). A. Leviella sp., external view of a left valve, sample CM31C (MNHN.F.F63317). B-C. Pokornyopsis sp. 1. B. Left lateral view of a carapace, sample CM31B (MNHN.F.F63318). C. Same specimen, dorsal view. D-E. Pokornyopsis? sp. 2. D. Left lateral view of a carapace, sample CM31A(MNHN.F.F63319). E. Right lateral view of a carapace, sample CM31A (MNHN.F.F63320). F. Pokornyopsis sp. 3, left lateral view of a carapace, sample CM31A (MNHN.F.F63321). G-I. Hungaroleberis sp. 1. G. Left lateral view of a carapace, sample CM31B (MNHN.F.F63322). H. Left lateral view of a carapace, sample CM31C (MNHN.F.F63323). I. Left lateral view of a carapace, sample CM31A (MNHN.F.F63324). J-L. Hungaroleberis sp. 2. J. Right lateral view of a carapace, sample CM31A (MNHN.F.F63325). K. Right lateral view of a carapace, sample CM31A (MNHN.F.F63326). L. Left lateral view of a carapace, sample CM31A (MNHN.F.F63327). M. Polycope sp. 1, lateral view of a carapace, sample CM31A (MNHN.F.F63328). N. Polycope sp. 2, lateral view of a carapace, sample CM31B (MNHN.F.F63329). O. Polycope sp. 3, lateral view of a carapace, sample CM31A (MNHN.F.F63330). P. Polycope sp. 4, lateral view of a carapace, sample CM31C (MNHN.F.F63331). Scale bars: $100 \mu \mathrm{m}$. 


\section{Discussion}

\section{Diversity and taxonomic composition of ostracod assemblages}

Each of the three samples collected from the Rhaetian sediments of the CM31 drill core 817LV performed on the Romanian Black Sea shelf yielded identifiable ostracods. In total, 72 species have been identified, belonging to 29 genera and 13 families. The genus Histriabairdia gen. nov. is newly described. Six species were previously known from the Triassic, seven are new (Bairdiacypris argonautaii sp. nov., Ceratobairdia? akhilleusi sp. nov., Histriabairdia pontuseuxinusensis gen. et sp. nov., Isobythocypris atalantella sp. nov., Petasobairdia amazonella sp. nov., Paracypris ovidi sp. nov. and Pseudomacrocypris? kerabani sp. nov.) and 59 are kept in open nomenclature due to poor preservation and/or paucity of material (including Bairdia sp. 7 in Mette \& Mohtat-Aghai 1999 and Bairdiacypris sp. in Forel et al. 2018, which are known from other localities from the Late Triassic). Table 1 provides a complete taxonomic list of the three assemblages from the Rhaetian of the Romanian Black Sea shelf. The composition of the ostracod assemblages retrieved from the studied samples is rather homogeneous, yet some variations in the distribution of species within the 13 families are visible, as shown in Fig. 14. The highest diversity in terms of species and genera occurs in samples CM31B and CM31C, with 46 species each and 23 and 24 genera, respectively. The assemblage from sample CM31A yielded 40 species distributed in 22 genera.

The three studied assemblages are very similar in terms of taxonomic composition and only differ by accessory genera. They are first characterized by the overall massive dominance of Bairdiidae, which constitutes $48 \%$ of the species in CM31A (19 species; genera Acratia, Bairdia, Bairdiacypris, Carinobairdia, Ceratobairdia, Fabalicypris, Histriabairdia gen. nov., Isobythocypris, Lobobairdia, Mirabairdia and Petasobairdia), 50\% in CM31B (23 species; genera Acratia, Bairdia, Bairdiacypris, Carinobairdia, Ceratobairdia, Hiatobairdia, Histriabairdia gen. nov., Isobythocypris, Lobobairdia and Petasobairdia) and 52\% in CM31C (24 species; genera Acratia, Bairdia, Bairdiacypris, Carinobairdia, Ceratobairdia, Hiatobairdia, Histriabairdia gen. nov., Isobythocypris, Lobobairdia and Petasobairdia). Paracyprididae are second in terms of species proportions: $15 \%$ in CM31A (6 species), $11 \%$ in CM31B (5 species) and 11\% in CM31B (4 species), represented by "Aglaiocypris" and Paracypris in all three assemblages. The third most important component of these assemblages are Sigilliidae, only represented by the genus Cardobairdia: $10 \%$ in CM31A, $9 \%$ in CM31B and 7\% in CM31C. Polycopidae are fourth in terms of importance, only represented by the genus Polycope, and are $8 \%$ of the species in CM31A, and 7\% in CM31B and CM31C. Cylindroleberididae (genus Hungaroleberis), Cytherellidae (genera Cytherelloidea, Leviella), Healdiidae (genus Hungarella), Cytheruridae (genera Judahella, gen. indet.) and Pontocyprididae (genus Pseudomacrocypris) are accessory components of all assemblages. Thaumathocyprididae (genus Pokornyopsis) only occur in CM31A and CM31B. Bythocytheridae are only found in CM31B and CM31C. Macrocyprididae and Rectonariidae only occur in CM31B and CM31C, respectively.

\section{Palaeoenvironmental implications}

The autochthonous or allochthonous nature of ostracod assemblages is generally discussed by the proportion of complete carapaces vs isolated valves, as well as the demographic structure of populations (e.g., Oertli 1971; Boomer et al. 2003). In the studied assemblages from the Rhaetian deposits of the Romanian Black Sea shelf, isolated valves occur but they are not dominant and thus indicate that some transportation might have occurred. However, ten of the species are composed of adults and successive ontogenetic stages (Figs 3-4): if transportation occurred, it may have been very limited.

A first important feature for palaeoenvironmental conditions is here the overall dominance of Bairdiidae, which is a good indicator of open marine conditions throughout the investigated interval. The low diversity and abundance of Cytheruridae, with the absence of Eucytherura Müller, 1894, is worth noting in the 


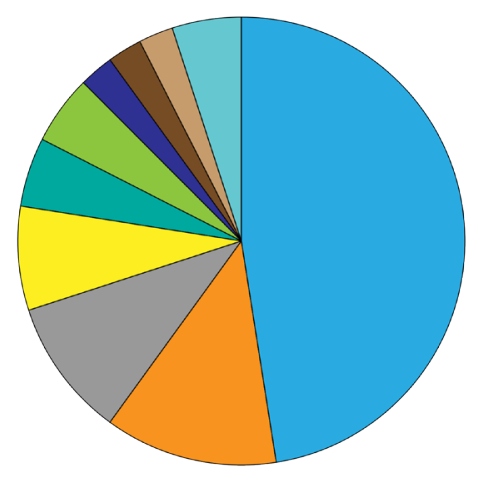

31A

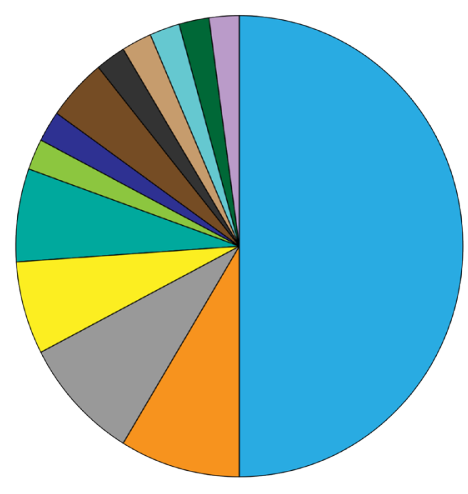

31B

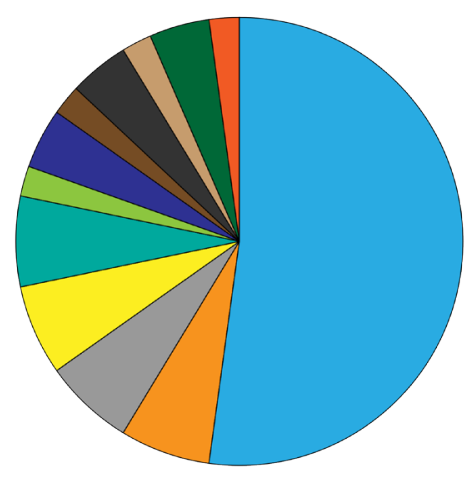

$31 \mathrm{C}$

$\begin{array}{|ll|}\square \text { Bairdiidae } & \text { Healdiidae } \\ \square \text { Paracyprididae } & \text { Bythocytheridae } \\ \square \text { Sigillidae } & \square \text { Cytheruridae } \\ \square \text { Polycopidae } & \square \text { Thaumatocyprididae } \\ \square \text { Pontocyprididae } & \text { Cytheroidea indet. } \\ \square \text { Cylindroleberididae } & \square \text { Macrocyprididae } \\ \text { Cytherellidae } & \text { Rectonariidae }\end{array}$

Fig. 14. Circular diagrams of faunal composition of ostracod assemblages by number of species in each group from drill core CM31, Black Sea, Romanian Continental Shelf, Rhaetian, Late Triassic. 
present assemblages from the Rhaetian deposits of the Romanian Black Sea shelf. During the Mesozoic, cytherurids were restricted to shelf depths, including marginal marine habitats: they are crawlers that dwell on and in soft, relatively fine-grained substrates (silt and fine sand) and generally indicate shallow marine conditions with clear and well-oxygenated waters (e.g., Ballent \& Whaltey 2000, 2009). In line with this observation is the limited occurrence of Cytherellidae, which are generally significant in warm water littoral environments (e.g., Sohn 1962; Kornicker 1963; Urlichs 1972; Whatley et al. 1995) and absent from shallow cold waters in the Mesozoic (Whatley 1988). For instance, Cytheruridae occurred on the outer platform-upper slope zone offshore of Turkey during the Carnian, Late Triassic (Forel et al. 2019a), but their absence from Early Jurassic deposits of Turkey (Lord \& Lambourne 1991) and Austria (Honigestein et al. 2014) has been considered as indicative of bathyal and outer neritic-upper continental slope conditions, respectively. Consequently, the low diversity and abundance of both platycopids and cytherurids seem to point to relatively deep conditions.

Accessory components of each assemblage document slight environmental differences. Bythocytheridae found in Middle and Late Triassic deep-sea deposits (e.g., Crasquin-Soleau \& Grădinaru 1996; Kozur et al. 2000; Sebe et al. 2013; Forel et al. 2019a) are rare but present in CM31B and CM31C, possibly demonstrating a relatively deeper position for these two assemblages compared to CM31A. Rectonariidae, which were typical Palaeozoic deep-sea taxa, occur in CM31C. Similarly, the thaumathocypridid Pokornyopsis is benthic and its maximum distribution depth is $200 \mathrm{~m}$ (Aubrecht \& Kozur 1995). These Thaumathocyprididae only occur in CM31A and CM31B, which may indicate that CM31A was deposited under a slightly shallower water column. To sum up, the ostracod assemblages collected from the Rhaetian deposits of the borehole $817 \mathrm{LV}$ drilled on the Romanian Black Sea shelf indicate open marine conditions. They furthermore document an increase in water depth from CM31A, deposited in the deep subtidal zone, to CM31C, which may correspond to the outer shelf area in normal marine oxygenation.

\section{A point on the genus Petasobairdia Chen, 1982}

Petasobairdia amazonella sp. nov., newly described here from the Rhaetian deposits of the Romanian Black Sea shelf calls for a necessary clarification of the concept of Petasobairdia. Petasobairdia Chen, 1982 was erected to accommodate bairdiids with laterally compressed antero-ventral and posteroventral margins, with the dorsal margin of the LV bearing a ridge, nodes, denticulation or horny spines (Chen \& Shi 1982). This genus was described from the Late Permian of South China and is said to occur from the Devonian to the Triassic (Chen \& Shi 1982). The Devonian occurrences were, however, not discussed or detailed by Chen \& Shi (1982), a fact that was also underlined by Becker (2001). Kozur (1985) provided a range extension from the Early Carboniferous to the Late Permian for Petasobairdia and created two tribes within the newly erected subfamily Ceratobairdiinae: Ceratobairdiini and Petasobairdiini. In this concept, Ceratobairdiini (Early Permian-Recent) contains Ceratobairdia Sohn, 1954 and Havanardia Pokorny, 1968, and have a strongly inflated or winged ventrolateral area with the flattened ventral surface delimited by a ventral strip, the dorsal margin of LV strongly convex, smooth or with small numerous or one or two large spines, and the lateral surface smooth to reticulate (Kozur 1985). Conversely, Petasobairdiini (Late Permian-Rhaetian) contains Petasobairdia and Alatobairdia Kristan-Tollmann, 1971, and have one or two long spines on the dorsal margin of the LV, with the lateral surface smooth to reticulate (Kozur 1985). In the same paper, Praelobobairdia Kozur, 1985 was erected (subfamily Carinobairdiinae), differing from Petasobairdia by the laterally compressed dorsal overlap of LV over RV, while it bears horns or spines in Petasobairdia. On this new basis, Kozur (1985) re-attributed the Permian species Petasobairdia nantongensis Chen, 1982, Petasobairdia sp. in Chen \& Shi 1982 and P. subnantongensis Chen in Shi \& Chen, 1987 to Praelobairdia.

However, the taxonomic status of Praelobobairdia and Petasobairdia, should they be synonyms or not, has been unstable and unclear, highlighting the confusion between these genera. This taxonomic 
re-attribution has indeed never been followed in subsequent papers scrutinizing assemblages from the Permian-Triassic interval worldwide, referring for instance to Petasobairdia nantongensis (e.g., Shi \& Chen 1987; Yi 2004; Crasquin-Soleau et al. 2004; Crasquin et al. 2010; Forel \& Crasquin 2011; Forel et al. 2015; Chitnarin et al. 2017), which implies that most authors implicitly consider Praelobairdia as a junior synonym of Petasobairdia. The only contributions that consider these two genera as distinct deal with the Late Permian assemblages from Israel (Gerry et al. 1987; Honigstein et al. 2005) and the Middle Permian of Thailand (Chitnarin et al. 2008), this last example illustrating the instability of authors regarding their concept of these genera. Praelobobairdia has been considered as a possible synonym of Petasobairdia (Becker 2001: 286). Here, this view is followed and two morphs are discriminated: the spinose/horny forms and the laterally compressed forms. This choice might be debatable, as it relies on the still unresolved issue of how to integrate the ornamentation features of Bairdiidae in their classification. However, considering the two morphological groups as distinct genera or as morphs within a unique genus is only a matter of semantics, which does not impair the scientific clustering of these species. The only necessity is thus to maintain a stability of taxonomic concepts until new analyses can be carried out on the significance of outer ornaments in bairdiids and of the phylogeny of Permian and Triassic ornate forms that have been proposed to be rooted in the Early Permian Petasobairdia (Forel \& Crasquin 2020). Here we follow Kozur (1985) in re-attributing Ceratobairdia gombasekensis Kozur, 1971 from the Ladinian, Middle Triassic, of Slovakia (Kozur 1971b) to Petasobairdia as its ventral margin is not winged. Conversely, Praeloboairdia cf. silenitiformis Kozur, 1985 from the Middle Permian of Thailand (Chitnarin et al. 2008) is not here re-attributed to Petasobairdia, because the dorsal margin on the LV is hardly visible. Praelobobairdia sp. from the Early-Middle Triassic of Israel (Honigstein \& Crasquin 2011) cannot be confirmed, as the illustrated specimens are heavily covered with sediment.

\section{Stratigraphic and geographical distributions: updates and discussion}

Research on Late Triassic marine ostracods worldwide sheds new light to the pivotal mechanisms underlying the Palaeozoic-Mesozoic turnover, i.e., the residual occurrence of Palaeozoic taxa up to the Late Triassic (e.g., Kozur et al. 2000; Forel et al. 2019a) and the early roots of typical Triassic and Jurassic taxa (e.g., Kristan-Tollmann 1983, 1993; Forel et al. 2019b). As summarized in Forel \& Moix (2020), three major hypotheses have been proposed for the area of origin of Mesozoic tethyan ostracods: western America (Kristan-Tollmann \& Tollmann 1981, 1982; Kristan-Tollmann 1986a, 1986b, 1988), western Tethys (Bate 1977; Lord 1988) and eastern Tethys (Bate 1977; Lord 1988; Kristan-Tollmann 1983, 1993; Ketmuangmoon et al. 2018; Forel et al. 2019b). An analysis performed at the generic and species levels documented the complexity of these issues and the intricate mixture of westward migration of genera (e.g., Nodobairdia as shown in Ketmuangmoon et al. 2018; Carinobairdia as shown in Forel et al. 2019b) and eastward migration of species (e.g., Nodobairdia mammilata; Forel \& Moix 2020). Our understanding of the radiative explosion of ornate Bairdiidae characterizing the Triassic has recently been renewed by the introduction of a new phylogenetic model for their radiation and evolution through the Permian and the Triassic (Forel \& Crasquin 2020). In reaching the general aim of unravelling the Palaeozoic-Mesozoic transition, new occurrences and spatial distribution are major tools, at all taxonomic levels.

Cardobairdia was described from the Middle Eocene of Trinidad (van den Bold 1960). It has since turned out to be typical of Jurassic layers of western Tethys (e.g., Apostolescu 1959; Szczechura \& Blaszyk 1968; Harloff \& Jäger 1994; Monostori 1996; Boomer et al. 1998; Ainsworth \& Boomer 2001; Olempska \& Blaszyk 2001; Beher 2004). The large geographical distribution of its oldest records in the Early Jurassic of England, Ireland (Lord \& Boomer 1988; Ainsworth 1986, 1987) and Australia (Lord et al. 1993) documented that Cardobairdia may have radiated earlier in the Triassic. The earliest roots of Cardobairdia have recently been identified in the Carnian of Slovenia (Forel et al. 2020b) and the present assemblages display the highest Triassic diversity for this genus which is, at the time of writing, not known from anywhere else during the Rhaetian. At this time, the early history of this 
important Jurassic taxon is purely western-tethyan, from its Carnian roots to the present record of a major diversification in the Rhaetian.

In terms of species, Judahella andrusovi Kozur \& Bolz in Bunza \& Kozur, 1971 (Fig. 11L-M) is a long lasting species known from the Late Anisian (Kristan-Tollmann 1983) to the Rhaetian (Urlichs 1972; Kristan-Tollmann et al. 1980, 1991a; Kristan-Tollmann 1988; Mette et al. 2012; this paper). This species was described from the Norian, Late Triassic, of Austria (Bunza \& Kozur 1971), but it radiated from the south Chinese shores on the eastern side of Tethys in the Anisian, Middle Triassic. The spatio-temporal distribution of this species is a new indicator of the importance of the easternmost Tethys (South China Block and Indochina Block) for the radiation and subsequent dispersal of taxa that later became typical for the Triassic or Jurassic of the western tethyan area (e.g., Kristan-Tollmann 1983; Ketmuangmoon et al. 2018; Forel et al. 2019b).

The Triassic myodocopid fossil record from the North Dobrogea is rich compared to that of contemporaneous assemblages (e.g., Crasquin-Soleau \& Grădinaru 1996; Sebe et al. 2013; Forel \& Grădinaru 2018). Until the present record, the thaumatocyprid Pokornyopsis was only known from the Jurassic (e.g., Triebel 1941; Bartenstein 1949; Aubrecht \& Kozur 1995; Tóth \& Cséfán 2018). Kozur (1974) and Aubrecht \& Kozur (1995) mentioned the occurrence of specimens of Pokornyopsis in the late Triassic, but these were not further discussed or illustrated and Tóth \& Csefan (2018) revealed that the specimens were lost. The present analysis of Rhaetian deposits from the Romanian Black Sea shelf therefore reports the first verified record of Pokornyopsis in the Triassic. Pokornyopsis is considered as the forerunner of recent anchialine and submarine cave ostracod taxa, including Danielopolina Kornicker \& Sohn, 1976. In the Jurassic, Pokornyopsis occurs in submarine neptunian dykes and crevices and it is assumed that this stock may have "survived in the stable, old crevicular habitat from the Mesozoic Tethys" with "extremely small changes within this stock since the Triassic" (Aubrecht \& Kozur 1995: 8). However, the sediments observed from the Romanian Black Sea shelf show no indication of crevicular deposition. Similarly, a project currently in progress by the present two authors on ostracods from Late Triassic neptunian dykes lack any trace of Pokornyopsis. This would rather indicate that Pokornyopsis did not colonize crevicular systems in the Triassic. Hungaroleberis has been reported from the Wordian, Middle Permian, of Greece (Crasquin-Soleau \& Baud 1998) to the Bajocian, Middle Jurassic, of Hungary (Tóth \& Cséfán 2018), and the species reported in this paper (Fig. 13G-L) correspond to its first known occurrence in the Triassic worldwide.

Data documenting the residual survivorship of Palaeozoic taxa in the Triassic have considerably increased in the recent years and have shown the importance of deep-water areas. Of them, Palaeocopida, which were among the chief components of the Palaeozoic fauna, have been traced up to the Carnian, Late Triassic, documenting their last presence in deep waters (Forel et al. 2019a). Palaeozoic deep-sea taxa such as Beecherellidae have also been increasingly documented up to the Middle Triassic (Kozur 1970; Crasquin-Soleau \& Grădinaru 1996; Sebe et al. 2013) and even to the Carnian, Late Triassic (Forel et al. 2019a). These taxa can now be considered as representative of deep waters of the tethyan Triassic and are irreplaceable proxies to trace deep-water conditions during this interval. Similar recognition is difficult in the Jurassic because of the absence of these distinctive facies-ostracods and deep-water assemblages are recognized by their dissimilarity with known coeval material (e.g., Lord \& Lambourne 1991; Honigstein et al. 2014). Rectonariidae were also important Palaeozoic deep-water taxa (e.g., Gründel 1962; Blumenstengel 1979; Kozur 1991) and they were considered as victims of the endPermian/Triassic event until their discovery in Carnian deep-water sediments of Turkey (Forel et al. 2019a). The present record of Rectonariidae gen. 1 in Forel et al. 2019 (Fig. 10E) is important for several reasons: 1) it represents the latest known occurrence of unquestionable facies-type ostracods related to the deep-sea, 2) it extends the record of Rectonariidae to the brink of the end-Triassic extinction after its Lazarus record from the Changhsingian to the Carnian and 3) it documents a maintained radiation in 
the deep sea, as this genus is new to science and restricted to the Triassic, ranging from the Carnian to the Rhaetian.

\section{Conclusions}

Ostracods of Rhaetian, Late Triassic, age have been extracted from drill core CM31, sampled from borehole 817 Lebăda Vest, drilled on the western Romanian portion of Black Sea shelf. The ostracod assemblage is composed of 72 species, which represent 29 genera and 13 families. The genus Histriabairdia gen. nov. is newly described to accommodate species from the Triassic-Jurassic interval that were previously attributed to the extent genus Anchistrocheles. Seven new species are described: Bairdiacypris argonautaii sp. nov., Ceratobairdia? akhilleusi sp. nov., Histriabairdia pontuseuxinusensis gen. et sp. nov., Isobythocypris atalantella sp. nov., Petasobairdia amazonella sp. nov., Paracypris ovidi sp. nov. and Pseudomacrocypris? kerabani sp. nov. The environmental affinities of the recovered taxa suggest an outer shelf environment with relatively normal marine oxygenation. We discuss the record of the genus Petasobairdia in the Permian-Triassic interval, and its synonymy with Praelobobairdia. The present material further provides the youngest record of Rectonariidae as well as the oldest verified occurrence of Pokornyopsis, the forerunner of recent anchialine and submarine cave ostracod taxa. However, contrary to previous claims, the Rhaetian material analysed here shows that Pokornyopsis may not have been troglobytic in the Triassic.

\section{Acknowledgements}

EG acknowledges the late Dr Doru Luțac, the former Director of PETROMAR-Constanța, for allowing free access to the documentation of boreholes and core materials, in the frame of the research project 'Analysis of Conditions of Generation, Migration and Accumulation of Hydrocarbons in the Continental Shelf of the Black Sea, in Order to Direct the Geological Research Works', Bucharest 1989, coordinated by the late Prof. Dr Bujor Almășan, the founder and former director of the Bureau of Expertise and Consulting, University of Bucharest. Iuliana Lazăr (University of Bucharest) is kindly acknowledged for assisting in the microfacies analysis and definition of the depositional environement. Nikita Bragin (Russian Academy of Sciences) is thanked for providing data on the Rhaetian limestone within the Kichik-Sarman olistolith, in mountainous Crimea. Milos Siblik (Czech Academy of Sciences) and Evgeny S. Sobolev (A.A. Trofimuk Institute of Petroleum Geology and Geophysics SB RAS) are gratefully acknowledged for assisting in the taxonomic assignment of the Rhaetian brachiopods. We are also grateful to Prof. Alan Lord (Senckenberg Forschungsinstitut, Frankfurt-am-Main, Germany) and Dr Emőke Tóth (Eötvös Loránd University, Budapest, Hungary) for their constructive remarks that greatly improved an earlier version of this contribution. We finally thank the editorial team for their work on the present contribution.

\section{References}

Aiello G., Barra D. \& Bonaduce G. 1996. Anchistrocheles interrupta a new deep-water ostracod species (Pussellinae, Ostracoda) from the Plio-Pleistocene of the Mediterranean Basin. Bollettino della Società paleontologica italiana 34: 271-274.

Ainsworth N.R. 1986. Toarcian and Aalenian Ostracoda from the Fastnet Basin, offshore south-west Ireland. Bulletin of the Geological Survey of Ireland 3: 277-336.

Ainsworth N.R. 1987. Pliensbachian Ostracoda from the Fastnet Basin, offshore Southwest Ireland. Bulletin of the Geological Survey of Ireland 4 (1): 41-62.

Ainsworth N.R. 1989. Rhaetian, Hettangian and Sinemurian Ostracoda from the Fastnet Basin, offshore southwest Ireland. Bulletin of the Geological Survey of Ireland 4 (2): 107-150. 
Ainsworth N.R. 1990. Uppermost Rhaetian to lower Bajocian Ostracoda from the Porcupine, Slyne, Erris and Donegal Basins, offshore west Ireland. Bulletin of the Geological Survey of Ireland 4 (3): $169-200$.

Ainsworth N.R. \& Boomer I. 2001. Upper Triassic and Lower Jurassic stratigraphy from exploration well L134/5-1, offshore Inner Hebrides, west Scotland. Journal of Micropalaeontology 20: 155-168. https://doi.org/10.1144/jm.20.2.155

Ainsworth N.R. \& Horton N.F. 1986. Mesozoic micropalaeontology of exploration well Elf 55/30-1 from the Fasnet Basin, offshore southwest Ireland. Journal of Micropalaeontology 5 (1): 19-29. https://doi.org/10.1144/jm.5.1.19

Ainsworth N.R., O’Neill M. \& Rutherford M.M. 1989. Jurassic and Upper Triassic biostratigraphy of the North Celtic Sea and Fastnet Basins. In: Batten D.J. \& Keen M.C. (eds) Northwest European Micropalaeontology and Palynology: 1-44. British Micropalaeontological Society Series, Totnes, UK.

Al-Khahab S.A. \& Al-Halawachi J.M. 2018. Ostracoda species from Upper Triassic of Baluti Formation (Amadiya Section) in Northern Iraq. Iraqi National Journal of Earth Sciences 18 (2): 61-68.

Anderson F.W. 1964. Rhaetic Ostracoda. Great Britain Geological Survey Bulletin 21: 133-174.

Apostolescu V. 1959. Ostracodes du Lias du Bassin de Paris. Revue de l'Institut français du Pétrole 14 : $795-826$.

Assereto R. 1972. Notes on the Anisian biostratigraphy of the Gebze area (Kocaeli Peninsula, Turkey). Zeitschrift der deutschen geologischen Gesellschaft 123: 435-444.

Aubrecht R. \& Kozur H. 1995. Pokornyopsis (Ostracoda) from submarine fissure fillings and cavities in the Late Jurassic of Czorsztyn Unit and the possible origin of the Recent anchialine faunas. Neues Jahrbuch für Geologie und Paläontologie, Abhandlungen 196 (1): 1-17.

Ayress M.A., Whatley R., Downing S.E. \& Millson K.J. 1995. Cainozoic and Recent deep sea cytherurid Ostracoda from the southwestern Pacific and eastern Indian Oceans, part 1: Cytherurinae. Records of the Australian Museum 47 (2): 203-223. https://doi.org/10.3853/j.0067-1975.47.1995.237

Ballent S.C. 1994. New marine microfaunas from the Triassic-Jurassic boundary in the Atuel River area (Mendoza, Argentina). $4^{\text {th }}$ International Congress on Jurassic Stratigraphy and Geology, Mendoza, Abstracts: 55.

Ballent S.C. \& Whatley R. 2000. The composition of Argentinian Jurassic marine ostracod and foraminiferal faunas: environment and zoogeography. Geobios 33 (3): 365-376.

https://doi.org/10.1016/s0016-6995(00)80164-3

Ballent S.C. \& Whatley R. 2009. Taxonomy and zoogeography of the Mesozoic cytherurid Ostracoda from west-central Argentina. Palaeontology 52 (1): 193-218.

https://doi.org/10.1111/j.1475-4983.2008.00827.x

Bartenstein H. 1949. Thaumatocypris bettenstaedti n. sp. aus dem nordwestdeutschen Lias (Ostrac.). Senckenbergiana 30 (1/3): 95-98.

Bate R.H. 1977. Jurassic Ostracoda of the Atlantic Basin. In: Swain F.M. (ed.) Stratigraphic Micropaleontology of Atlantic Basin and Borderlands: 231-244. Elsevier Scientific Pub., New York, Amsterdam. https://doi.org/10.1016/s0920-5446(08)70354-6

Bate R.H. 1978. The Trias. In: Bate R.H. \& Robinson E. (eds) A Stratigraphical Index of British Ostracoda: 175-188. Geological Journal, Special Issue 8. 
Becker G. 2001. The Superfamily Bairdiacea Sars, 1888 - 1. Family Bairdiidae Sars, 1888 (Palaeozoic members only). Contributions to Palaeozoic Ostracod Classification [POC] 18. Neues Jahrbuch für Geologie und Paläontologie, Abhandlungen 220 (2): 267-294.

https://doi.org/10.1127/njgpa/220/2001/267

Becker G. 2002. Contributions to Palaeozoic Ostracod Classification [POC], no. 24, Palaeozoic Ostracoda: the standard classification scheme. Neues Jahrbuch für Geologie und Paläontologie, Abhandlungen 226: 165-228. https://doi.org/10.1127/njgpa/226/2002/165

Beher E. 2004. Ostracodenfauna und Biostratigraphie im Ober-Sinemurium von Süddeutschland und der Nordschweiz. Stuttgarter Beiträge zur Naturkunde, Serie B (Geologie und Paläontologie) 349: 1-170.

Beher E., Franz M. \& Schweizer V. 2001. Zur Ostracodenfauna des Ober-Sinemurium und untersten Unter-Pliensbachium im Gebiet von Tuningen (Baden-Württemberg). Neues Jahrbuch für Geologie und Paläontologie, Abhandlungen 219: 329-391. https://doi.org/10.1127/njgpa/219/2001/329

Belloni S. 1960. La serie Retica del Monte Rena (Prealpi Bergamasche). Rivista italiana di Paleontologia e Stratigrafia 66 (2): 155-172.

Bennett C.E. 2008. A review of the Carboniferous colonisation of non-marine environments by ostracods. Senckenbergiana Lethaea 88: 37-46. https://doi.org/10.1007/bf03043976

Bennett C.E., Siveter D.J., Davies S.J., Williams M., Wilkinson I.P., Browne M. \& Miller C.G. 2012. Ostracods from freshwater and brackish environments of the Carboniferous of the Midland Valley of Scotland: the early colonization of terrestrial water bodies. Geological Magazine 149 (3): 366-396. https://doi.org/10.1017/s0016756811000719

Blake J.F. 1876. Subclass Entomostraca. In: Tate R. \& Blake J.F. (eds) The Yorkshire Lias: 429-435. John Van Voorst, London.

Blumenstengel H. 1979. Die Ostrakodenfauna der Wocklumeria-Stufe (Oberdevon) bei Saalfeld im Thüringer Schiefergebirge. Zeitschrift für Geologische Wissenschaften 7 (4): 521-557.

van den Bold W.A. 1960. Eocene and Oligocene Ostracoda of Trinidad. Micropaleontology 6 (2): 145196. https://doi.org/10.2307/1484466

Bolz H. 1969. Der "bairdoppilate" Verschluss und Skulptur-Unterschiede bei Bairdien (Ostrac.) der alpinen Obertrias. Senckenbergiana Lethaea 50: 411-431.

Bolz H. 1971a. Late Triassic Bairdiidae and Healdiidae. In: Oertli H.J. (ed.) Paléoécologie des Ostracodes: 717-745. Bulletin du Centre de Recherche, SNPA, 5 (Supplement).

Bolz H. 1971b. Die Zlambach-Schichten (alpine Obertrias) unter besonderer Berücksichtigung der Ostrakoden, 1: Ostrakoden der Zlambach-Schichten, besonders Bairdiidae. Senckenbergiana Lethaea 52: $129-283$.

Boomer I., Ainsworth N.R. \& Exton J. 1998. A re-examination of the Pliensbachian and Toarcian Ostracoda of Zambujal, west-central Portugal. Journal of Micropalaeontology 17 (1): 1-14.

https://doi.org/10.1144/jm.17.1.1

Boomer I., Duffin C.J. \& Swift A. 1999. Arthropods 1 - Crustaceans. In: Swift A. \& Martill D.M. (eds) Fossils of the Rhaetian Penarth Group: 129-148. Palaeontological Association Field Guide to Fossils, vol. 9.

Boomer I., Horne D.J. \& Slipper I.J. 2003. The use of ostracods in palaeoenvironmental studies or what can you do with an ostracod shell? Palaeontological Society Papers 9: 153-179.

https://doi.org/10.1017/s1089332600002199 
Bradfield H.H. 1935. Pennsylvanian Ostracoda of Ardmore Basin, Oklahoma. Bulletin of American Paleontology 22: 1-145.

Brady G.S. 1868. Description of Ostracoda. In: Folin D. \& Périer L. (eds) Les Fonds de la Mer, Etude internationale sur les Particularités nouvelles des Regions sous-marines 1: 49-112.

https://doi.org/10.5962/bhl.title.13261

Brady G.S. 1870. Description of Ostracoda. In: Folin D. \& Périer L. (eds) Les fonds de la mer, etude internationale sur les particularités nouvelles des regions sous-marines 12-16 (1-16): 177-256. https://doi.org/10.5962/bhl.title.13261

Brady G.S. 1880. Report on the Ostracoda dredged by H.M.S. Challenger during the years 1873-1876. The Voyage of H.M.S. Challenger: Zoology 1 (3): 1-184.

Brady G.S. 1890. On Ostracoda collected by H.B. Brady in the South Seas Islands. Transactions of the Royal Society of Edinburgh 35 (14): 489-525. https://doi.org/10.1017/s0080456800017749

Brady G.S. \& Norman A.M. 1889. A monograph of the marine and freshwater Ostracoda of the North Atlantic and of North Western Europe. Section I. Podocopa. Scientific Transactions of the Royal Dublin Society 2: 63-270. https://doi.org/10.1080/00222938909460549

Brand E. 1990. Biostratigraphische Untergliederung des Ober-Bathonium im Raum Hildesheim, Nordwestdeutschland, mittels Ostracoden und Korrelation ihrer Vertikal-Reichweiten mit AmmonitenZonen. Geologisches Jahrbuch A121: 119-274.

Brandão S.N. 2008. New species of Bairdioidea (Crustacea, Ostracoda) from the Southern Ocean and discussions on Bairdoppilata simplex (Brady, 1880), ?Bairdoppilata labiata (Müller, 1908) and Bythopussella aculeata (Müller, 1908). Zootaxa 1866 (1): 373-452.

https://doi.org/10.11646/zootaxa.1866.1.19

Brandão S.N., Hoppema M., Kamenev G.M., Karanovic I., Riehl T., Tanaka H., Vital H., Yoo H. \& Brandt A. 2019. Review of Ostracoda (Crustacea) living below the Carbonate Compensation Depth and the deepest record of a calcified ostracod. Progress in Oceanography 178: e102144.

https://doi.org/10.1016/j.pocean.2019.102144

Breman E. 1975. Ostracodes in a bottom core from the deep southeastern basin of the Adriatic Sea. I, II. Koninklijke Nederlandse Akademie van Wetenschappen, Proceedings, Ser. B 78: 198-218.

Bunza G. \& Kozur H. 1971. Beiträge zur Ostracodenfauna der tethyalen Trias. GeologischPaläontologische Mitteilungen Innsbruck 1: 1-76.

Cabioch G., Anglada R. \& Babinot J.-F. 1986. Microfaunes et paléoenvironnements des récifs frangeants quaternaires de Mamié et Ricaudy (Nouvelle-Calédonie). Cahiers de Micropaléontologie 1 (1 \& 2): $5-36$.

Cabral M.C., Loureiro I.M., Duarte L.V. \& Azerêdo A.C. 2013. Registro da extincão dos Metacopina (Ostracoda, Crustacea) no Toarciano de Rabacal, região de Coimbra. Comunicações Geológicas 100: 63-68.

Cătuneanu O. \& Maftei A. 1994. The Romanian Shelf of the Black Sea. In: Ionesi L. (ed.) The Geology of the Platform Units and the North-Dobrogean Orogen: 227-260. Ed. Tehn., Bucharest. [In Romanian.]

Chen D.Q. \& Shi C.G. 1982. Latest Permian Ostracoda from Nantong, Jiangsu and from Miannyang, Hubei. Bulletin of Nanjing Institute of Geology and Palaeontology, Academia Sinica 4: 105-152. [In Chinese with English abstract.]

Chitnarin A., Crasquin S., Chonglakmani C., Broutin J., Grote P.J. \& Thanee N. 2008. Middle Permian ostracods from Tak Fa limestone, Phetchabun Province, central Thailand. Geobios 41: 341-353.

https://doi.org/10.1016/j.geobios.2007.09.001 
Chitnarin A., Crasquin S., Forel M.-B. \& Tepnarong P. 2017. Ostracods (Crustacea) of the Early-Middle Permian (Cisarulian-Guadalupian) from Central Thailand (Indochina Block): Part II, Orders Podocopida, Platycopida and Myodocopida. Geodiversitas 39 (4): 651-690. https://doi.org/10.5252/g2017n4a1

Christensen O.B. 1962. Ostracodtyper fra Keuper-Rhaet lagserien i dybdeboringerne ved Harte og Ullerslev. Meddelelser fra Dansk Geologisk Forening 15: 90-98.

Colalongo M.L. 1965. Gli ostracodi della serie di Le Castella (Calabria). Giornale di Geologia 33: $83-123$.

Cooper C.L. 1946. Pennsylvanian ostracodes of Illinois. Illinois State Geological Survey Bulletin 70: $1-177$.

Crasquin S. \& Forel M.-B. 2014. Ostracods (Crustacea) through Permian-Triassic events. Earth-Science Reviews 137: 52-64. https://doi.org/10.1016/j.earscirev.2013.01.006

Crasquin S., Carcione L. \& Martini R. 2008. Permian ostracods from the Lercara Formation (Middle Triassic to Carnian?, Sicily, Italy). Palaeontology 51: 537-560.

https://doi.org/10.1111/j.1475-4983.2008.00755.x

Crasquin S., Forel M.-B., Feng Q.L., Yuan A.H., Baudin F. \& Collin P.-Y. 2010. Ostracods (Crustacea) through the Permian-Triassic boundary in South China: The Meishan stratotype (Zhejiang Province). Journal of Systematic Palaeontology 8: 331-370. https://doi.org/10.1080/14772011003784992

Crasquin S., Forel M.-B., Yuan A.H., Nestell G. \& Nestell M. 2017. Species of Hollinella (Palaeocopida: Ostracoda: Crustacea) as stratigraphical indices of the Late Permian-Early Triassic post-extinction interval. Journal of Systematic Palaeontology 16 (3): 213-224.

https://doi.org/10.1080/14772019.2017.1283648

Crasquin S., Sciuto F. \& Reitano A. 2018. Late Carnian (Tuvalian, Tropites dilleri zone) ostracods (Crustacea) from the Mufara Formation (Monte Scalpello, Central-Eastern Sicily, Italy). Annales de Paléontologie 104 (2): 129-142. https://doi.org/10.1016/j.annpal.2018.03.001

Crasquin-Soleau S. \& Baud A. 1998. New Permian ostracods from Greece (Hydra Island). Journal of Micropalaeontology 17: 131-152. https://doi.org/10.1144/jm.17.2.131

Crasquin-Soleau S. \& Grădinaru E. 1996. Early Anisian ostracode fauna from the Tulcea unit (Cimmerian North Dobrogean Orogen, Romania). Annales de Paléontologie 82: 59-116.

Crasquin-Soleau S., Berra F. \& Rettori R. 2000. A Late Triassic ostracod assemblage from the Quattervals Nappe (Austroalpine, Northern Italy). Rivista italiana di Paleontologia e Stratigrafia 106 (2): 181-190.

Crasquin-Soleau S., Marcoux J., Angiolini L., Richoz S., Nicora A., Baud A. \& Bertho Y. 2004. A new ostracode fauna from the Permian-Triassic boundary in Turkey (Taurus, Antalya Nappes). Micropalaeontology 50: 281-296. https://doi.org/10.2113/50.3.281

Crasquin-Soleau S., Vaslet D. \& Le Nindre Y.M. 2005. Ostracods as markers of the Permian/Triassic boundary in the Khuff Formation of Saudi Arabia. Palaeontology 48: 853-868.

https://doi.org/10.1111/j.1475-4983.2005.00476.x

Crasquin-Soleau S., Galfetti T., Bucher H., Kershaw S. \& Feng Q.L. 2007. Ostracod recovery in the aftermath of the Permian-Triassic crisis: Palaeozoic-Mesozoic turnover. Hydrobiologia 585: 13-27. https://doi.org/10.1007/s10750-007-0625-6

Dagys A.S. 1974. Triassic brachiopods. Transactions of Institute of Geology and Geophysics, Novosibirsk 214: 1-323. [In Russian.] 
Delo D.M. 1930. Some Upper Carboniferous Ostracoda from the shale basin of Western Texas. Journal of Paleontology 4: 152-178.

Dépêche F. \& Crasquin-Soleau S. 1992. Triassic marine ostracodes of the Australian margin (Holes 759B, 760B, 761C, 764A and 764B). Proceedings of the Ocean Drilling Program, Scientific Results 122: 453-462. https://doi.org/10.2973/odp.proc.sr.122.177.1992

de Vos A.P.C. 1953. Three new commensal ostracods from Limnoria lingorum (Rathke). Beaufortia 4: $21-31$

Dinu C., Orban T. \& Grădinaru E. 1989. Tectonics of the Dobrogean Continental Shelf of the Black Sea. Condition for the Generation, Migration and Accumulation of Hydrocarbons on the Romanian Continental Shelf of the Black Sea: 86-100. Internal Report, vol. 1. Faculty of Geology and Geophysics, Bucharest University. [In Romanian.]

Dinu C., Wong H.C., Țambrea D. \& Mațenco L. 2005. Stratigraphic and structural characteristics of the Romanian Black Sea shelf. Tectonophysics 410: 417-435. https://doi.org/10.1016/j.tecto.2005.04.012

Donze P. 1966. Ostracodes de l'Hettangien entre Aubenas et Privas (Ardèche). Travaux du Laboratoire de Geologie de la Faculté de Sciences de Lyon 13: 121-139.

Dreyer E. 1967. Mikrofossilien des Rot und Lias von SW-Brandenburg. Jahrbuch für Geologie 1: 491531.

Fantini Sestini N. 1988. Anisian ammonites from Gebze area (Kockaeli Peninsula, Turkey). Rivista italiana di Paleontologia e Stratigrafia 94 (1): 35-80.

Flügel E. 2004. Microfacies of Carbonate Rocks: Analysis, Interpretation and Application. Springer Verlag, Berlin, Heidelberg.

Forel M.-B. \& Crasquin S. 2011. In the aftermath of the Permian-Triassic boundary mass-extinction: new ostracod (Crustacea) genus and species from South Tibet. Geodiversitas 33: 247-263. https://doi.org/10.5252/g2011n2a3

Forel M.-B. \& Crasquin S. 2020. Bounded by crises: an updated view of the evolution of marine ostracods during the Triassic. Marine Micropaleontology. https://doi.org/10.1016/j.marmicro.2020.101925

Forel M.-B. \& Grădinaru E. 2018. First report of ostracods (Crustacea) associated with Bithynian (Anisian, Middle Triassic) Tubiphytes-microbial reef in the North Dobrogean Orogen (Romania). Papers in Palaeontology 4 (2): 211-244. https://doi.org/10.1002/spp2.1103

Forel M.-B. \& Moix P. 2020. Late Triassic ostracods from the Lycian Nappes, southwestern Turkey: implications on taxonomy and palaeobiogeographical distribution. Geodiversitas 191 (30): 1-18. https://doi.org/10.1051/bsgf/2020035

Forel M.-B., Crasquin S., Hips K., Kershaw S., Collin P.-Y. \& Haas J. 2013a. Biodiversity evolution through the Permian-Triassic boundary event: Ostracods from the Bükk Mountains, Hungary. Acta Palaeontologica Polonica 58 (1): 195-219. https://doi.org/10.4202/app.2011.0126

Forel M.-B., Crasquin S., Kershaw S. \& Collin P.-Y. 2013b. In the aftermath of the end-Permian extinction: the microbialite refuge. Terra Nova 25: 137-143. https://doi.org/10.1111/ter.12017

Forel M.-B., Crasquin S., Chitnarin A., Angiolini L. \& Gaetani M. 2015. Precocious sexual dimorphism and Lilliput effect of Neo-Tethyan Ostracoda (Crustacea) through the Permian-Triassic boundary. Palaeontology 58: 409-454. https://doi.org/10.1111/pala.12151

Forel M.-B., Ozsvárt P. \& Moix P. 2018. Carnian (Late Triassic) ostracods from the Sorgun Ophiolitic Mélange (Southern Turkey): Taxonomy, palaeoenvironment and evidence of predation. Palaeontologia Electronica 21.2.26A: 1-23. https://doi.org/10.26879/852 
Forel M.-B., Tekin U.K., Okuyucu C., Bedi Y., Tuncer A. \& Crasquin S. 2019a. Discovery of a longterm refuge for ostracods (Crustacea) after the end-Permian extinction: a unique Carnian (Late Triassic) fauna from the Mersin Mélange, southern Turkey. Journal of Systematic Palaeontology 17 (1): 9-58. https://doi.org/10.1080/14772019.2017.1391342

Forel M.-B., Thuy B. \& Wisshak M. 2019b. Digging into the ancestral stocks of Jurassic lineages: Ostracods (Crustacea) from Carnian (Late Triassic) sponge mounds from the Maantang Formation (South China). Bulletin de la Société géologique de France 190 (9): 1-28. https://doi.org/10.1051/bsgf/2019009

Forel M.-B., Bercovici A. \& Yu J.X. 2020a. Ostracods after the end-Permian extinction in South China: insights into non-microbial survival. Micropaleontology 66 (5): 377-396.

Forel M.-B., Kolar-Jurkovšek T. \& Jurkovšek B. 2020b. Ostracods from the "Raibl Beds" (Carnian, Late Triassic) of Belca section in Karavanke Mountains, northwestern Slovenia. Geodiversitas 42 (21): 377-407. https://doi.org/10.5252/geodiversitas2020v42a21

Gaetani M. 2016. Brachiopods from the type-section of the Bithynian substage (Anisian, Middle Triassic, Northwestern Turkey). Rivista italiana di Paleontologia e Stratigrafia 122 (2): 61-76.

Gerry E., Honigstein A., Derin B. \& Flexer A. 1987. Late Permian ostracodes of Israel. Taxonomy, distribution, and paleogeographical implications. Senckenbergiana Lethaea 68 (1-4): 197-223.

Gliwa J., Forel M.-B., Crasquin S., Ghaderi A. \& Korn D. 2020. Ostracods from the end-Permian mass extinction in the Aras Valley section (north-west Iran). Papers in Palaeontology.

https://doi.org/10.1002/spp2.1330

Grădinaru E. 1984. Jurassic rocks of North Dobrogea: a depositional-tectonic approach. Revue roumaine de Géologie 28: 61-72.

Grădinaru E. 1995. Mesozoic rocks in North Dobrogea: an overview. In: Săndulescu M. \& Grădinaru E. (eds) Field Guidebook, Central and North Dobrogea, Romania, October 1-4, 1995. IGCP Project No. 369, Comparative Evolution of Peri-Tethyan Rift Basins: 17-26. Geological Institute of Romania, Bucharest.

Grădinaru E. 2000. Introduction to the Triassic geology of North Dobrogea Orogen. In: Grădinaru E. (ed.) Workshop on the Lower-Middle Triassic (Olenekian-Anisian) Boundary: 5-37. 7-10 June 2000, Tulcea, Romania, Conference and Field Trip. Field Trip Guide, Bucharest.

Grădinaru E. \& Gaetani M. 2019. Upper Spathian to Bithynian (Lower to Middle Triassic) brachiopods from North Dobrogea (Romania). Rivista italiana di Paleontologia e Stratigrafia 125 (1): 91-123.

Grădinaru E., Dinu C. \& Dragastan O. 1989. Stratigraphy of the Dobrogean Continental Shelf of the Black Sea. In: Almășan B. (ed.) Conditions for the Generation, Migration and Accumulation of Hydrocarbons on the Romanian Continental Shelf of the Black Sea: 39-85. Internal Report, vol. 1. Faculty of Geology and Geophysics, Bucharest University. [In Romanian.]

Greco A., Ruggieri G. \& Sprovieri R. 1974. La sezione calabriana di Monasterace (Calabria). Bollettino della Società paleontologica italiana 93: 151-179.

Gründel J. 1962. Zur Taxonomie der Ostracoden der Gattendorfia-Stufe Thüringens. Freiberger Forschungshefte 151: 51-105.

Gümbel C.W. 1869. VII. Ueber Foraminiferen, Ostracoden und mikroskopische Thier-Ueberreste in den St. Cassianer und Raibler Schichten. Jahrbuch der kaiserlich-königlichen geologischen Reichsanstalt 10: $175-186$.

Hammer Ø. \& Harper D.A.T. 2005. Paleontological Data Analysis. Blackwell, Oxford. 
Hammer Ø., Harper D.A.T. \& Ryan P.D. 2001. PAST: Palaeontological Statistics software package for education and data analysis. Palaeontologia Electronica 4: 9.

Harloff J. 1993. Ostracoden des Unter-Pliensbachiums in Baden-Württemberg. Stuttgarter Beiträge zur Naturkunde, Serie B, Geologie und Paläontologie 191: 1-214.

Harloff J. \& Jäger R. 1994. Ostracoden aus dem Lias der Kalkalpen Bayerns und Nordtirols. Stuttgarter Beiträge zur Naturkunde, Serie B, Geologie und Paläontologie 205: 1-63.

Herrig E. 1979a. Die Gattung Bairdia (Ostracoda, Crustacea) im Lias von Thüringen. Teil I. Zeitschrift für Geologische Wissenschaften 7 (5): 641-661.

Herrig E. 1979b. Ostrakoden aus dem Lias von Thüringen: Die Gattungen Bairdia (Teil II), Fabalicypris und Bairdiacypris. Zeitschrift für Geologische Wissenschaften 7 (6): 763-782.

Herrig E. 1992. Neue Ostrakoden aus verkieselten Kalksteinen der höheren Ober-Kreide (OberMaastricht) der Dänisch-Polnischen Furche/Ostsee, I. Zeitschrift für Geologische Wissenschaften 20: $27-49$.

Hillebrandt A.V., Krystyn L. \& Kürschner W.M. 2007. A candidate GSSP for the base of the Jurassic in the Northern Calcareous Alps (Kuhjoch section, Karwendel Mountains, Tyrol, Austria). ISJS Newsletter 34 (1): $2-20$.

Hillebrandt A.V., Krystyn L., Kürschner W.M., Bonis N.R., Ruhl M., Richoz S., Schobben M.A.N., Urlichs M., Bown P.R., Kment K., McRoberts C., Simms M. \& Tomasovych A. 2013. The Global Stratotype Sections and Point (GSSP) for the base of the Jurassic System at Kuhjoch (Karwendel Mountains, Northern Calcareous Alps, Tyrol, Austria). Episodes 36 (3): 162-198.

https://doi.org/10.18814/epiiugs/2013/v36i3/001

Hoare R.D., Svitko J.L. \& Stugeon M.T. 1999. Pennsylvanian Bairdiidae(Ostracoda) from the Appalachian Basin. Journal of Paleontology 73 (3): 437-453. https://doi.org/10.1017/s0022336000027967

Honigstein A. \& Crasquin S. 2011. Late Scythian-Anisian ostracods (Crustacea) from the Meged-2 borehole, central Israel. Journal of Micropalaeontology 30: 17-31.

https://doi.org/10.1144/0262-821x10-022

Honigstein A., Rosenfeld A. \& Derin B. 2005. Late Permian ostracodes: new subsurface material from Israel. Micropaleontology 51 (5): 405-422. https://doi.org/10.2113/gsmicropal.51.5.405

Honigstein A., Lord A.R. \& Thuy B. 2014. Early Jurassic ostracods from the Glasenbach Gorges, Northern Calcareous Alps, Austria, and evidence for upper slope deposition. Neues Jahrbuch für Geologie und Paläontologie, Abhandlungen 273 (1): 1-11. https://doi.org/10.1127/0077-7749/2014/0412

Horne D.J., Cohen A. \& Martens K. 2002. Taxonomy, morphology and biology of Quaternary and living Ostracoda. In: Holmes J.A. \& Chivas A. (eds) The Ostracoda: Applications in Quaternary Research: 5-36. Geophysical Monograph, American Geophysical Union, Washington DC.

https://doi.org/10.1029/131gm02

Jellinek T. 1989. Zwei neue Havanardia-Arten (Crustacea, Ostracoda, Bairdiidae) aus dem E-afrikanischen Küstengebeit (Madagascar und Kenia). Courier Forschungsinstitut Senckenberg 113: $37-47$.

Jones T.R. 1894. On the Rhætic and some Liassic Ostracoda of Britain. Quarterly Journal Geological Society of London 50: 156-169. https://doi.org/10.1144/gsl.jgs.1894.050.01-04.14

Kalvoda J., Melichar R., Babel O. \& Leichmann J. 2002. Late Proterozoic-Paleozoic tectonostratigraphic development and paleogeography of Brunovistulian terrane and comparison with other terranes at the SE margin of Baltica-Laurussia. Journal of the Czech Geological Society 47 (3): 81-102. 
Kaye P. 1965. Further Ostracoda from the British Lower Cretaceous. Senckenbergiana Lethaia 46: 7381.

Ketmuangmoon P., Chitnarin A., Forel M.-B. \& Tepnarong P. 2018. Diversity and paleoenvironmental significance of Middle Triassic ostracods (Crustacea) from northern Thailand: Pha Kan Formation (Anisian, Lampang Group). Revue de Micropaléontologie 61 (1): 3-22.

https://doi.org/10.1016/j.revmic.2017.11.001

Keyser D. 1995. Structural elements on the surface of ostracod shells. In: Riha J. (ed.) Ostracoda and Biostratigraphy: 5-10. Proceedings of the Twelfth International Symposium on Ostracoda, Prague, Czech Republic, 26-30 July 1994. Balkema, Rotterdam.

Khosla S.C. \& Jakhar S.R. 1999. A note on the ostracode fauna from the Jurassic of Jumara Dome, Kachchh. Journal of the Geological Society of India 54: 43-49.

Khosla S.C., Jakhar S.R., Manisha K. \& Dubey S. 2006. Middle Jurassic Ostracoda from the Jaisalmer Formation, Jaisalmer District, Rajasthan, India. Journal of the Palaeontological Society of India 51 (1): $1-31$.

Khosla S.C., Jakhar S.R. \& Manisha K. 2009. Atlas of the Middle Jurassic Ostracods from Western India. Department of Geology, Mohanlal Sukhadia University Udaipur, The Palaeontological Society of India, Lucknow, India.

Knitter H. 1983. Biostratigraphische Untersuchungen mit Ostracoden im Toarcien Süddeutschlands. Facies 8: 213-262. https://doi.org/10.1007/bf02536743

Kollmann K. 1960. Ostracoden aus der alpinen Trias. I. Parabairdia n. g. und Ptychobairdia n. g. (Bairdiidae). Jahrbuch der Geologischen Bundesanstalt 5: 79-105.

Kollmann K. 1963. Ostracoden aus der alpinen Trias. II. Weitere Bairdiidae. Jahrbuch der Geologischen Bundesanstalt 106: 121-203.

Korchagin O.A., Kuznetsova K.I. \& Bragin N.Y. 2003. Find of early planktonic foraminifers in the Triassic of the Crimea. Doklady Earth Sciences 390 (4): 482-486.

Kornicker L.S. 1963. Ecology and classification of Bahamian Cytherellidae (Ostracoda). Micropaleontology 9 (1): 61-70. https://doi.org/10.2307/1484607

Kotlyar G.V., Baud A., Pronina G.P., Zakharov Y.D., Vuks V.J., Newell M.K., Belyaeva G.V. \& Marcoux J. 1999. Permian and Triassic exotic limestone blocks of the Crimea. In: Crasquin-Soleau S. \& De Wever P. (eds) Peri-Tethys Stratigraphic Correlations 3: 299-323. Geodiversitas 21 (3).

Kozur H. 1968. Neue Ostracoden aus dem Röt und Muschelkalk des germanischen Binnenbeckens. Monatsberichte der deutschen Akademie der Wissenschaften zu Berlin 10: 498-519.

Kozur H. 1970. Neue Ostracoden-Arten aus dem Obersten Anis des Bakonyhochlandes (Ungarn). Berichte des naturwissenschaftlich-medizinischen Vereins in Innsbruck 58: 384-428.

Kozur H. 1971a. Die Bairdiacea der Trias. Teil I: Skulpturierte Bairdiidae aus Mitteltriassischen Flachwasserablagerungen. Geologisch-Paläontologische Mitteilungen Innsbruck 1 (3): 1-27.

Kozur H. 1971b. Die Bairdiacea der Trias. Teil II: Skulpturierte Bairdiidae aus mitteltriassischen Teifschelfablagerungen. Geologisch-Paläontologische Mitteilungen Innsbruck 1 (5): 1-21.

Kozur H. 1971c. Die Bairdiacea der Trias. Teil III: Einige neue Arten triassischer Bairdiacea und Bemerkungen zur Herkunft der Macrocyprididae (Cypridacea). Geologisch-Paläontologische Mitteilungen Innsbruck 1 (6): 1-18. 
Kozur H. 1972. Die Bedeutung triassischer Ostracoden fur stratigraphische und paläoökologische Untersuchungen. Mitteilungen der Gesellschaft der Geologie- und Bergbaustudenten in Österreich 21: 623-660.

Kozur H. 1974. Eine neue Gattung der Familie Polycopidae (Cladocopida, Ostracoda). Zeitschrift für geologische Wissenschaften 2 (7): 853-855.

Kozur H. 1985. Neue Ostracoden-Arten aus dem oberen Mittelkarbon (höheres Moskovian), Mittel- und Oberperm des Bükk-Gebirges (N-Ungarn). Geologisch-Paläontologische Mitteilungen S2: 1-145.

Kozur H. 1991. Permian deep-water ostracods from Sicily (Italy). Part 1. Taxonomy. Geologischpaläontologische Mitteilungen 3: 1-24.

Kozur H., Kampschuur W., Mulder-Blanken C.W.H. \& Simon O.J. 1974. Contribution to the Triassic ostracode faunas of the betic zone (southern Spain). Scripta Geologica 23: 1-56.

Kozur H., Aydin M., Demir O., Yakar H., Göncüoglu M.C. \& Kuru F. 2000. New stratigraphic and palaeogeographic results from the Palaeozoic and Early Mesozoic of the Middle Pontides (Northern Turkey) in the Azdavay, Devrekani, Küre and Inebolu areas: Implications for the Carboniferous-Early Cretaceous geodynamic evolution and some related remarks to the Karakaya Oceanic Rift Basin. Geologia Croatica 53: 209-268.

Kristan-Tollmann E. 1964. Zur Charakteristik triadischer Mikrofaunen. Paläontologische Zeitschrift 38 (1/2): 66-73. https://doi.org/10.1007/bf02987945

Kristan-Tollmann E. 1969. Zur stratigraphischen Reichweite der Ptychobairdien und Anisobairdien (Ostracoda) in der alpinen Trias. Geologica et Palaeontologica 3: 81-95.

Kristan-Tollmann E. 1970. Einige neue Bairdien (Ostracoda) aus der alpinen Trias. Neues Jahrbuch für Geologie und Paläontologie, Abhandlungen 135: 268-310.

Kristan-Tollmann E. 1971a. Weitere Beobachtungen an skulptierten Bairdiidae (Ostrac.) der alpinen Trias. Neues Jahrbuch für Geologie und Paläontologie, Abhandlungen 139: 57-81.

Kristan-Tollmann E. 1971b. Torohealdia n. gen., eine charakteristische Ostracoden-Gattung der obersten alpinen Trias. Erdoel-Erdgas-Zeitschrift 87: 50-54.

Kristan-Tollmann E. 1972. Die obertriadischen Arten der Ostracoden-Gattung Kerocythere Kozur \& Nicklas, 1970, und ihr stratigraphischer Wert. Erdoel-Erdgas-Zeitschrift 88: 43-49.

Kristan-Tollmann E. 1977a. On the development of the muscle-scar patterns in Triassic Ostracoda. In: Löffler H. \& Danielopol D. (eds) Aspects of Ecology and Zoogeography of Recent and Fossil Ostracoda: 133-143. Springer Verlag, The Hague, Junk.

Kristan-Tollmann E. 1977b. Zur Evolution des Schließmuskelfeldes bei Healdiidae und Cytherellidae (Ostracoda). Neues Jahrbuch für Geologie und Paläontologie 10: 621-639.

Kristan-Tollmann E. 1978. Bairdiidae (Ostracoda) aus den obertriadischen Cassianer Schichten der Ruones-Wiesen bei Corvara in Südtirol. Schriftenreihe der Erdwissenschaftlichen Kommissionen, Österreichische Akademie der Wissenschaften 4: 77-104.

Kristan-Tollmann E. 1983. Ostracoden aus dem Oberanis von Leidapo bei Guiyang in Südchina. In: Zapfe H. (ed.) Neue Beiträge zur Biostratigraphie der Tethys-Trias: 121-176. Springer Verlag, Berlin, Heidelberg.

Kristan-Tollmann E. 1986a. Beobachtungen zur Trias am Südostende der Tethys-Papua/Neuguinea, Australien, Neuseeland. Neues Jahrbuch für Geologie und Paläontologie, Monatshefte 4: 201-222. 
Kristan-Tollmann E. 1986b. Triassic of the Tethys and its relations with the Triassic of the Pacific realm. In: McKenzie K.G. (ed.) Shallow Tethys 2: 169-186. Proceedings of the International Symposium on Shallow Tethys 2, Wagga Wagga, Australia.

Kristan-Tollmann E. 1988. Unexpected microfaunal communities within the Triassic Tethys. Geological Society of London, Special Publication 37: 213-223. https://doi.org/10.1144/gsl.sp.1988.037.01.13

Kristan-Tollmann E. 1993. Zur paläogeographischen Verbreitung der Ostracoden-Gattung Hermiella an der Rhät/Lias-Grenze. Zitteliana 20: 331-342.

Kristan-Tollmann E. \& Gupta V.J. 1988. Die Übereinstimmung der unterrhätischen Mikrofauna der Zlambach- und Kiotomergel (Ostalpen-Himalaya). Newsletters on Stratigraphy 20 (1): 1-6.

Kristan-Tollmann E. \& Gramann F. 1992. 27. Paleontological evidence for the Triassic age of rocks dredged from the Northern Exmouth Plateau (Tethyan foraminifers, echinoderms, and ostracodes). Proceedings of the Ocean Drilling Program, Scientific Results 122: 463-474.

https://doi.org/10.2973/odp.proc.sr.122.186.1992

Kristan-Tollmann E. \& Tollmann A. 1981. Die Stellung der Tethys in der Trias und die Herkunft ihrer Fauna. Mitteilungen der österreichischen geologischen Gesellschaft 74/75: 129-135.

Kristan-Tollmann E. \& Tollmann A. 1982. Die Entwicklung der Tethystrias und Herkunft ihrer Fauna. Geologische Rundschau 71 (8): 987-1019. https://doi.org/10.1007/bf01821115

Kristan-Tollmann E., Tollmann A. \& Hamedani A. 1979. Beiträge zur Kenntnis der Trias von Persien. I. Revision der Triasgliederung. Rhätfazies in Raum von Isfaham und Kossener Fazieseinschlag bei Waliabad SE Abadeh. Mitteilungen der österreichischen geologischen Gesellschaft 70: 119-190.

Kristan-Tollmann E., Tollmann A. \& Hamedani A. 1980. Beiträge zur Kenntnis der Trias von Persien. II. Zur Rhätfauna von Bagerabad bei Isfahan (Korallen, Ostracoden). Mitteilungen der österreichischen geologischen Gesellschaft 73: 163-235.

Kristan-Tollmann E., Lobitzer H. \& Solti G. 1991a. Mikropaläontologie und Geochemie der Kössener Schichten des Karbonatplatform-Becken-Komplexes Kammerköhralm - Steinplatte (Tirol/Salzburg). In: Lobitzer H. \& Csaszar G. (eds) Jubiläumsschrift 20 Jahre geologische Zusammenarbeit ÖsterreichUngarn, Wien, Teil I: 155-191. Geologische Bundesanstalt, Vienna.

Kristan-Tollmann E., Haas J. \& Kovács S. 1991b. Karnische Ostracoden und Conodonten der Bohrung Zsámbék-14 im Transdanubischen Mittelgebirge (Ungarn). In: Lobitzer H. \& Csaszar G. (eds) Jubiläumsschrift 20 Jahre geologische Zusammenarbeit Österreich-Ungarn, Wien, Teil I: 193-219. Geologische Bundesanstalt, Vienna.

Krystyn L. 1987. Zur Rhät-Stratigraphie in den Zlambach-Schichten (vorläufiger Bericht). Sitzungsberichte der österreichischen Akademie der Wissenschaften in Wien, mathematischnaturwissenschaftliche Klasse 196 (1-4): 21-36.

Lethiers F. \& Crasquin-Soleau S. 1988. Comment extraire des microfossiles à tests calcitiques de roches calcaires dures. Revue de Micropaléontologie 31: 56-61.

Liebau A. 1977. Homologous Sculpture Patterns in Trachyleberididae and Related Ostracods. Nolit Publishing House, Belgrade.

Lord A.R. 1972. The ostracod genera Ogmoconcha and Procytheridea in the Lower Jurassic. Bulletin of the Geological Society of Denmark 21: 319-336.

Lord A.R. 1982. Metacopine ostracods in the Lower Jurassic. In: Bannar E.T. \& Lord A.R. (eds) Aspects of Micropalaeontology: 262-277. Allen \& Unwin, London.

https://doi.org/10.1007/978-94-011-6841-0_7 
Lord A.R. 1988. Ostracoda of the Early Jurassic Tethyan Ocean. In: Hanai T., Ikeya N. \& Ishizaki K. (eds) Evolutionary Biology of Ostracoda: Its Fundamentals and Applications: 855-868. Proceedings of the Ninth International Symposium on Ostracoda, Shizuoka, Japan, 1985. Developments in Palaeontology and Stratigraphy 11. Kodansha, Tokyo and Elsevier, Amsterdam. https://doi.org/10.1016/s0920-5446(08)70226-7

Lord A.R. \& Boomer I. 1988. The Lower and Middle Jurassic. In: Keen M.C., Lord A.R. \& Whatley R.C. (eds) British Micropalaeontological Society Field Guide 6: 1-22. The University College of Wales, Aberystwyth.

Lord A.R. \& Lambourne D.C. 1991. Lower Jurassic ostracods from the Western Pontides, Turkey. Geologica Romana 27: 381-387.

Lord A.R., Malz H. \& Apthorpe M. 1993. Lower Jurassic Ostracoda from off Western Australia. In: McKenzie K.G. \& Jones P.J. (eds) Ostracoda in the Earth and Life Sciences: 109-121. Proceedings of the Eleventh International Symposium on Ostracoda. A.A. Balkema, Rotterdam, Brookfield.

Maddocks R.F. 1968. Commensal and free-living species of Pontocypria Müller, 1894 (Ostracoda, Pontocyprididae) from the Indian and Southern Oceans. Crustaceana 15: 121-136.

https://doi.org/10.1163/156854068x00962

Maddocks R.F. 1969. Revision of Recent Bairdiidae (Ostracoda). United States National Museum Bulletin 295: 1-126. https://doi.org/10.5479/si.03629236.295.1

Maddocks R.F. 1975. Recent Bairdiidae (Ostracoda) from Ascension Island. Crustaceana 28 (1): 53-65. https://doi.org/10.1163/156854075x00874

Maddocks R.F. 1976. Pussellinae are interstitial Bairdiidae (Ostracoda). Micropaleontology 22 (2): 194-214. https://doi.org/10.2307/1485400

Maddocks R.F. 1991. Living and fossil Macrocyprididae (Ostracoda). University of Kansas Paleontological Contributions Monograph 2: 1-285.

Maddocks R.F. 2005. Three new species of podocopid Ostracoda from hydrothermal vent fields at $9^{\circ} 50^{\prime} \mathrm{N}$ on the East Pacific Rise. Micropaleontology 51 (5): 345-372.

https://doi.org/10.2113/gsmicropal.51.5.345

Maddocks R.F. 2013. New and poorly known species of Neonesidea (Bairdiidae, Ostracoda, Crustacea) from French Frigate Shoals, the Hawaiian Islands. Zootaxa 3608 (6): 457-510.

https://doi.org/10.11646/zootaxa.3608.6.3

Maddocks R.F. 2015. New and poorly known species of Bairdoppilata and Paranesidea (Bairdiidae, Ostracoda) from French Frigate Shoals and O'ahu, the Hawaiian Islands. Zootaxa 4059 (2), 277-317. https://doi.org/10.11646/zootaxa.4059.2.3

Maddocks R.F. 2018. Flapper valve and hayfork: Functional anatomy and taxonomic potential of the gastric mill of Bairdioidea (Ostracoda, Podocopida). Zootaxa 4378 (1): 1-39.

https://doi.org/10.11646/zootaxa.4378.1.1

Maddocks R.F. \& Illife T.M. 1991. Anchialine podocopid Ostracoda of the Galapagos Islands. Zoological Journal of the Linnean Society 103: 75-99. https://doi.org/10.1111/j.1096-3642.1991.tb00898.x

Maddocks R.F. \& Steineck P.L. 1987. Ostracoda from experimental wood-island habitats in the deep sea. Micropaleontology 33: 318-355. https://doi.org/10.2307/1485572

Maddocks R.F. \& Wouters K. 1990. Triebelina? pustulata Keij, 1974 from the Maldive Islands: more homeomorphy in the ornate Bairdiidae (Ostracoda). Bulletin de l'Institut royal des Sciences naturelles de Belgique, Biologie 60: 173-180. 
Malz H. 1988. The Bairdia dynasty review - activities - aspects. In: Hanai T., Ikeya N. \& Ishizaki K. (eds) Evolutionary Biology of Ostracoda: Its Fundamentals and Applications: 75-80. Proceedings of the Ninth International Symposium on Ostracoda, Shizuoka, Japan, 1985. Developments in Palaeontology and Stratigraphy 11. Kodansha, Tokyo and Elsevier, Amsterdam.

https://doi.org/10.1016/s0920-5446(08)70173-0

Malz H. \& Lord A.R. 1988. Recent ornate bairdiid Ostracoda: origin and distribution. In: Hanai T., Ikeya N. \& Ishizaki K. (eds) Evolutionary Biology of Ostracoda: Its Fundamentals and Applications: 63-74. Proceedings of the Ninth International Symposium on Ostracoda, Shizuoka, Japan, 1985. Developments in Palaeontology and Stratigraphy 11. Kodansha, Tokyo and Elsevier, Amsterdam. https://doi.org/10.1016/s0920-5446(08)70172-9

Mazzini I. \& Gliozzi E. 2000. Occurrence of fossil and Recent Microceratina Swanson 1980 (Ostracoda, Eucytherurinae) in the Mediterranean. Micropaleontology 46: 143-152. https://doi.org/10.2113/46.2.143

McCoy F. 1844. A Synopsis of the Characters of the Carboniferous Limestone Fossils of Ireland. Dublin University Press, Dublin. https://doi.org/10.5962/bhl.title.11559

McKenzie K.G. 1967. Saipanellidae: a new family of podocopid Ostracoda. Crustaceana 13: 103-113. https://doi.org/10.1163/156854067x00125

McKenzie K.G. 1982. Palaeozoic-Cenozoic Ostracoda of Tethys. Bollettino della Società paleontologica italiana 21 (2-3): 311-326.

Méhes G. 1911. Über Trias-Ostrakoden aus dem Bakony. Resultate der wissenschaftlichen Erforschung des Balatonsees. Anhang zu Band 1, Teil 1, Paläontologie der Umgebung des Balatonsees 3: 1-38.

Mette W. \& Mohtat-Aghai P. 1999. Ostracods and Foraminifera from Upper Triassic intrashelf basin deposits in the Northern Calcareous Alps. Geologisch-Paläontologische Mitteilungen Innsbruck 24: $45-77$.

Mette W., Elsler A. \& Korte C. 2012. Palaeoenvironmental changes in the Late Triassic (Rhaetian) of the Northern Calcareous Alps: clues from stable isotopes and microfossils. Palaeogeography, Palaeoclimatology, Palaeoecology 350: 62-72. https://doi.org/10.1016/j.palaeo.2012.06.013

Mette W., Honigstein A. \& Crasquin S. 2015. Deep-water ostracods from the Middle Anisian (Reifling Formation) of the Northern Calcareous Alps (Austria). Journal of Micropalaeontology 34: 71-91. https://doi.org/10.1144/jmpaleo2014-009

Michelsen O. 1975. Lower Jurassic biostratigraphy and ostracods of the Danish Embayment. Danmarks Geologiske Undersøgelser, Series 2 104: 1-287.

Mirăuță E. \& Gheorghian D. 1975. Norian conodonts and foraminifers from North Dobrogea. Dări de Seamă ale Şedințelor, Institutul de Geologie și Geofizică 61 (3): 47-46.

Mirăuță E., Gheorghian D. \& Bădiceanu M. 1993. Données biostratigraphiques sur la Formation de Cataloi (Dobrogea de Nord, Roumanie). Romanian Journal of Statigraphy 75: 21-27.

Monostori M. 1995. Environmental significance of the Anisian Ostracoda fauna from the Forrás Hill near Felsöórs (Balatón Highland, Transdanubia, Hungary). Acta Geologica Hungarica 39: 37-56.

Monostori M. 1996. Pliensbachian ostracod fauna from condensed limestones of the Bakony Mts. (Transdanubian Central Range, Hungary). Fragmenta Mineralogica et Palaeontologica 18: 31-61.

Monostori M. 2008. Comparative study of the Pliensbachian and Toarcian ostracods in the Gerecse and Mecsek Mountains, Hungary. Hantkeniana 6: 17-31. 
Monostori M. \& Tóth E. 2013. Ladinian (Middle Triassic) silicified ostracod faunas from the Balaton Highland (Hungary). Rivista italiana di Paleontologia e Stratigrafia 119: 303-323.

Monostori M. \& Tóth E. 2014. Additional Middle to Upper Triassic ostracod faunas from the boreholes of Transdanubian Central Range (Hungary). Hantkeniana 9: 21-43.

Moore R.C. 1961. Treatise on Invertebrate Paleontology. Arthropoda 3, Crustacea, Ostracoda. Geological Society of America and University of Kansas Press.

Morales-Ramires A. \& Jakob J. 2008. Seasonal vertical distribution, abundance, biomass and biometrical relationships of ostracods in Golfo Dulce, Pacific coast of Costa Rica. Revista de Biologia tropical 56: $125-147$.

Mostafawi N. 1989. Limnische und marine Ostracoden aus dem Neogen der Insel Rhodos (Griechenland). Courier Forschungsinstitut Senckenberg 113: 117-157.

Oertli H.J. 1971. The aspect of ostracode fauna - a possible new tool in petroleum sedimentology. In: Oertli H.J. (eds) Paléoécologie des Ostracodes: 137-151. Bulletin du Centre de Recherches de Pau, SNPA.

Oertli H.J. 1972. Jurassic ostracodes of DSDP Leg 11 (sites 100 and 105) - Preliminary account. Initial Reports of the Deep-Sea Drilling Project 11: 645-657. https://doi.org/10.2973/dsdp.proc.11.122.1972

Okay A. \& Görür N. 2007. Tectonic evolution models for the Black Sea. In: Yilmaz P.O. \& Isaksen G.H. (eds) Oil and Gas of the Greater Caspian Area: 13-16. AAPG Studies in Geology 55. https://doi.org/10.1306/1205833st553249

Okay A. \& Nikishin A.M. 2015. Tectonic evolution of the southern margin of Laurasia in the Black Sea region. International Geology Review 57 (5-8): 1051-1076.

https://doi.org/10.1080/00206814.2015.1010609

Okay A. \& Topuz G. 2017. Variscan Orogeny in the Black Sea region. International Journal of Earth Sciences 106 (2): 569-592. https://doi.org/10.1007/s00531-016-1395-z

Okay A. \& Tüysüz O. 1999. Tethyan sutures of northern Turkey. In: Durand B., Jolivet L., Horváth F. \& Séranne M. (eds) The Mediterranean Basins: Tertiary Extension within the Alpine Orogen: 475-515. Special Publications 156. Geological Society, London. https://doi.org/10.1144/gsl.sp.1999.156.01.22

Okay A., Șengör A.M.C. \& Görür N. 1994. Kinematic history of the opening of the Black Sea and its effect on the surrounding regions. Geology 22 (3): 267-270.

https://doi.org/10.1130/0091-7613(1994)022<0267:KHOTOO>2.3.CO;2

Okay A., Altiner D. \& Kiliç A.M. 2015. Triassic limestone, turbidites and serpentinite - the Cimmeride orogeny in the Central Pontides. Geological Magazine 152 (3): 460-479.

https://doi.org/10.1017/s0016756814000429

Okay A., Altiner D., Sunal G., Aygül M., Akdoğan R., Altiner S. \& Simmons M.D. 2018. Geological evolution of the Central Pontides. In: Simmons M.D., Tari G.C. \& Akay A.I. (eds) Petroleum Geology of the Black Sea: 33-67. Special Publications 464. Geological Society, London.

https://doi.org/10.1144/sp464.3

Okay A., Sunal G., Sherlock S., Kylander-Clark A.R.C. \& Özcan E. 2020. İzmir-Ankara suture as a Triassic to Cretaceous plate boundary - data from Central Anatolia. Tectonics 39 (5).

https://doi.org/10.1029/2019TC005849

Olempska E. 2001. Palaeozoic roots of the sigilliid ostracods. Marine Micropalentology 41: 109-123. https://doi.org/10.1016/s0377-8398(00)00062-1 
Olempska E. \& Blaszyk J. 2001. A boreal ostracod assemblage from the Callovian of Lukow area, Poland. Acta Palaeontologica Polonica 46 (4): 553-582.

Patte E. 1926. Etudes paléontologiques relatives à la géologie de l'Est du Tonkin (Paléozoïque et Trias). Bulletin du Service géologique de l'Indochine 15 (1): 1-240.

Reuss A.E. 1869. Zur fossilen Fauna der Oligocänschichten von Gaas. Sitzungsberichte der österreichischen Akademie der Wissenschaften, mathematisch-naturwissenschaftliche Klasse, Abteilung 1 59 (3): 446-488.

Riccardi A.C., Damborenea S.E., Mancenido M.O. \& Iglesia Llanos M.P. 2004. The Triassic/Jurassic boundary in the Andes of Argentina. Rivista italiana di Paleontologia e Stratigrafia 110 (1): 69-76.

Rutherford M.M. \& Ainsworth N.R. 1989. Micropalaeontological and stratigraphical recognition of the Triassic-Jurassic boundary in the North Celtic Sea and Fastnet Basins. In: Batten D.J. \& Keen M.C. (eds) Northwest European Micropalaeontology and Palynology: 47-65. Ellis Horwood, Chichester.

Salas M.J. 2007. Assessing the biodiversity of the Ordovician ostracods from the Argentine Precordillera. Journal of Paleontology 81: 1442-1453. https://doi.org/10.1666/06-003r.1

Salas M.J., Vannier J. \& Williams M. 2007. Early Ordovician ostracods from Argentina: their bearing on the origin of binodicope and palaeocope clades. Journal of Paleontology 81 (6): 1384-1395.

https://doi.org/10.1666/05-134.1

Sars G.O. 1866. Oversigt af marine Ostracoder. Norske Videnskaps-Akademis Forhandlingar 1865: $1-130$.

Schornikov E.I. 1990. Evolution and classification of Bythocytheridae. Courier Forschungsinstitut Senckenberg 123: 291-302.

Sciuto F. 2012. New ostracod species from Lower Pleistocene sediments from Capo Milazzo (NE Sicily). Bollettino della Società paleontologica italiana 51 (2): 117-125.

Sciuto F. 2015. Palaeoenviromental and palaeogeographical traits on deep-water ostracod assemblages from the Lower Pleistocene sediments along the Ionian side of Mount Etna (Sicily, Italy). Carnets de Géologie 15: 179-197. https://doi.org/10.4267/2042/57945

Sciuto F. \& Pugliese N. 2013. Description of two new species of ostracods from the Strait of Messina (central Mediterranean). Zoosystema 35 (1): 35-44. https://doi.org/10.5252/z2013n1a4

Sebe E.G., Crasquin S. \& Grădinaru E. 2013. Early and Middle Anisian deep-water ostracods (Crustacea) from North Dobrogea (Romania). Revue de Paléobiologie 32: 509-529.

Seghedi A. 2012. Palaeozoic formations from Dobrogea and Pre-Dobrogea - an overview. Turkish Journal of Earth Sciences 21 (5): 669-721.

Shi C.G. \& Chen D.Q. 1987. The Changhsingian ostracodes from Meishan, Changxing, Zhejiang. Stratigraphy and Palaeontology of Systemic Boundaries in China; Permian and Triassic Boundary 5: 23-80. [In Chinese with English abstract.]

Sivhed U. 1980. Lower Jurassic ostracodes and stratigraphy of western Skåne, southern Sweden. Sveriges geologiska Undersökning, Serie Ca 50: 1-84.

Siveter D.J. 1984. Habitats and modes of life of Silurian ostracods. In: Bassett M.G. \& Lawson J.D. (eds). Autecology of Silurian Organisms: 71-85. Special Papers in Palaeontology 32. The Palaeontological Association, London. 
Siveter D.J. 2008. Ostracods in the Palaeozoic? Senckenbergiana Lethaea 88: 1-9. https://doi.org/10.1007/bf03043973

Siveter D.J. \& Vannier J.M.C. 1990. The Silurian myodocope ostracode Entomozoe from the Pentland Hills, Scotland, its taxonomic, ecological and phylogenetic significance and the affinity of bolbozoid myodocopes. Transactions of the Royal Society of Edinburgh, Earth Sciences 81 (1): 45-67. https://doi.org/10.1017/s0263593300005125

Siveter D.J., Vannier J.M.C. \& Palmer D. 1991. Silurian myodocopes, pioneer pelagic ostracods and the chronology of an ecological shift. Journal of Micropalaeontology 10: 151-173.

https://doi.org/10.1144/jm.10.2.151

Sohn I.G. 1954. Ostracoda from the Permian of the Glass Mountains, Texas. United States Geological Survey Professional Paper 264-A: 1-24. https://doi.org/10.3133/pp264a

Sohn I.G. 1960. Paleozoic species of Bairdia and related genera. United States Geological Survey Professional Paper 330-A: 1-120. https://doi.org/10.3133/pp330a

Sohn I.G. 1962. The ostracode genus Cytherelloidea, a possible indicator of paleotemperature. United States Geological Survey Professional Paper 450-D: 144-147. https://doi.org/10.3133/pp450d

Sohn I.G. 1968. Triassic ostracodes from Makhtesh Ramon, Israel. Bulletin of the Geological Survey of Israel 44: 1-71.

Sohn I.G. 1983. Ostracodes of the "Winifrede Limestone" (Middle Pennsylvanian) in the region of the proposed Pennsylvanian System stratotype, West Virginia. Bulletins of American Paleontology 84 (316): 1-53.

Sohn I.G. 1987. Middle and Upper Triassic marine Ostracoda from the Shublik Formation, northeastern Alaska. United States Geological Survey Bulletin 1664: C1-C24.

Starostenko V., Janik T., Yegorova T., Farfuliak L., Czuba W., Środa P., Thybo H., Artemieva I., Sosson M., Volfman Y., Kolomiyets K., Lysynchuk D., Omelchenko V., Gryn D., Guterch A., Komminaho K., Legostaeva O., Tiira T. \& Tolkunov A. 2015. Seismic model of the crust and upper mantle in the Scythian Platform: the DOBRE-5 profile across the north western Black Sea and the Crimean Peninsula. International Geophysical Journal 201 (1): 406-428. https://oi.org/10.1093/gji/ggv018

Stephenson R. \& Schellart W.P. 2010. The Black Sea back-arc basin: insights to its origin from geodynamic models of modern analogues. Geological Society, London, Special Publications 340 (1): 11-21. https://doi.org/10.1144/sp340.2

Styk O. 1958. Triassic microfauna in the neighbourhood of Chrzanow and the north- western part of the Mesozoic periphery of the Święty Krzyż Mts. Micropalaeontological Researches in Poland 3: 163-176. [In Polish.]

Swain F.M. 2000. Micro-Ostracoda from the Eocene of North Carolina: a suggested interstitial faunule. Revista española de Micropaleontología 32: 411-420.

Swift A. 2003. An ostracod fauna from the upper Langport Member (Penarth Group: Rhaetian, Upper Triassic) near Watchet, west Somerset (UK), including two new species of Eucytherura and Cytherelloidea praepulchella $\mathrm{n}$. nom. Journal of Micropalaeontology 22: 127-136. https://doi.org/10.1144/jm.22.2.127

Sylvester-Bradley P.C. 1947. Some ostracod genotypes. Annals and Magazine of Natural History, Series 1113 (99): 192-199. https://doi.org/10.1080/00222934608654541

Szczechura J. \& Blaszyk J. 1968. Cardobairdia inflata n. sp. from the Middle Jurassic of Poland and its taxonomic position within Ostracoda. Acta Palaeontologica Polonica 13: 185-197. 
Tabuki R. \& Hanai T. 1999. A new sigillid ostracod from submarine caves of the Ryukyu Islands, Japan. Palaeontology 42 (4): 569-593. https://doi.org/10.1111/1475-4983.00086

Țambrea D., Dinu C. \& Sâmpetrean E. 2002. Characteristics of the tectonics and lithostratigraphy of the Black Sea Shelf, offshore Romania. In: Dinu C. \& Mocanu V. (eds) Geology and Tectonics of the Romanian Black Sea Shelf and its Hydrocarbon Potential: 29-42. Bucharest Geoscience Forum, Special Volume, $2^{\text {nd }}$ ed. Vergiliu, Bucharest.

Tanaka H. \& Hayashi R. 2019. Chelonocytherois omutai gen. et sp. nov. (Crustacea: Ostracoda) from the back of loggerhead sea turtles. Zootaxa 4624 (4): 507-522. https://doi.org/10.11646/zootaxa.4624.4.4

Tari G., Fallah M., Kosi W., Schleder, Z., Turi V. \& Krezsek C. 2015. Regional rift structure of the western Black Sea Basin: map-view kinematics. In: Post P.J., Coleman J. Jr, Rosen N.C., Brown D.E., Roberts-Ashby T, Rahn P. \& Rowan M. (eds) Petroleum Systems in "Rift" Basins: 372-395. GeoScience World, McLean, VA. https://doi.org/10.5724/gcs.15.34.0372

Titterton R. \& Whatley R. 1988. Recent Bairdiinae (Crustacea, Ostracoda) from the Solomon Islands. Journal of Micropalaeontology 7 (2): 111-142. https://doi.org/10.1144/jm.7.2.111

Tóth E. \& Cséfán T. 2018. Rare myodocopid ostracods from Mesozoic sections of Hungary: summary, revision and description of new taxa. Zootaxa 4374 (3): 350-374.

https://doi.org/10.11646/zootaxa.4374.3.2

Triebel E. 1941. Zur Morphologie und Ökologie der fossilen Ostracoden. Mit Beschreibung einiger neuer Gattungen und Arten. Senckenbergiana 23: 294-400.

Tüysüz O. 2018. Cretaceous geological evolution of the Pontides. In: Simmons M.D., Tari G.C. \& Okay A.I. (eds) Petroleum Geology of the Black Sea: 69-94. Special Publications 464. Geological Society, London. https://doi.org/10.1144/sp464.9

Ulrich E.O. \& Bassler R.S. 1923. Paleozoic Ostracoda: their morphology, classification and occurence. In: Maryland Geological Survey (ed.) Silurian: 271-391. Johns Hopkins Press, Baltimore.

Urlichs M. 1971. Variability of some ostracods from the Cassian Beds (Alpine Triassic) depending on the ecology. Bulletin du Centre de Recherches Pau-SNPA 5: 695-715.

Urlichs M. 1972. Ostracoden aus den Kössener Schichten und ihre Abhängigkeit von der Ökologie. Mitteilungen der Gesellschaft der Geologie- und Bergbaustudenten in Österreich 21: 661-710.

Urlichs M. \& Krystyn L. 2016. Stratigraphic significance of the early Rhaetian ostracods from the proposed Norian/Rhaetian GSSP At Steinbergkogel (Late Triassic, Upper Austria). Albertiana 43: 1923.

Vannier J.M.C. \& Abe K. 1992. Recent and early Palaeozoic myodocope ostracodes: functional morphology, phylogeny, distribution and lifestyles. Palaeontology 35 (3): 485-517. Available from https://www.biodiversitylibrary.org/page/49777513 [accessed 16 Nov. 2020].

Wang S. 1978. Late Permian and Early Triassic ostracods of Western Guizhou and Northeastern Yunnan. Acta Palaeontologica Sinica 17: 277-308.

Warne M.T. 1990. Bythocyprididae (Ostracoda) from the Miocene of the Port Phillip and Western Port basins, Victoria. Proceedings of the Royal Society of Victoria 102 (2): 105-115.

Warne M.T. \& Whatley R. 2016. Neohornibrookella sorrentae (Chapman and Crespin, 1928) and allied ostracod taxa from the Neogene of southeastern Australia: Systematic and palaeoceanographical relationships, palaeoecology and palaeobiogeography. Marine Micropaleontology 125: 110-133.

https://doi.org/10.1016/j.marmicro.2016.04.003 
Wei M., Li Y.W., Jiang Z.W. \& Xie L.C. 1983. Subclass Ostracoda. In: Chengdu Institute of Geology and Mineral Resources (eds) Palaeontological Atlas of Southwest China, Guizhou. Volume of Microfossils: 23-254. Geological Publishing House, Beijing. [In Chinese.]

Whatley R. 1988. Patterns and rates of evolution in Mesozoic Ostracoda. Developments in Palaeontology and Stratigraphy 11: 1021-1040. https://doi.org/10.1016/s0920-5446(08)70236-x

Whatley R. \& Boomer I.D. 2000. Systematic review and evolution of the early Cytheruridae (Ostracoda). Journal of Micropalaeontology 19: 139-151. https://doi.org/10.1144/jm.19.2.139

Whatley R. \& Downing S. 1984. Middle Miocene Ostracoda from Victoria, Australia. Revista española de Micropaleontologia 15(3): 347-407.

Whatley R., Cooke P.C.B. \& Warne M.T. 1995. Ostracoda from Lee Point on Shoal Bay, Northern Australia: Part 1 - Cladocopina and Platycopina. Revista española de Micropaleontologia 27: 69-89.

Williams M., Leng M.L., Stephenson M.H., Andrews J.E., Wilkinson I.P., Siveter D.J., Horne D.J. \& Vannier J.M.C. 2006. Evidence that Early Carboniferous ostracods colonised coastal flood plain brackish water environments. Palaeogeography, Palaeoclimatology, Palaeoecology 230: 299-318.

https://doi.org/10.1016/j.palaeo.2005.07.021

Yajima M. 1987. 830. Pleistocene Ostracoda from the Atsumi Peninsula, Central Japan. Transactions and Proceedings of the Palaeontological Society of Japan 146: 49-76.

Yasuhara M., Sztybor K., Rasmussen T.L., Okahashi H., Sato R. \& Tanaka H. 2018. Cold-seep ostracods from the western Svalbard margin: direct palaeo-indicator for methane seepage? Journal of Micropalaeontology 37: 139-148. https://doi.org/10.5194/jm-37-139-2018

Yi W. 2004. Ostracodes from the Upper Permian and Lower Triassic at the Kongtongshan section of Datian, Fujian. Acta Palaeontologica Sinica 43: 556-570.

Yurttaş-Özdemir Ü. 1971. Macrofauna and biostratigraphy of the Tepeköy Triassic on the Kocaeli Peninsula. Maden Tetkik ve Arama Enstitüsü Dergisi 77: 57-98. [In Turkish.]

Zorn I. 2010. Ostracodal type specimens stored in the paleontological collection of the Geological Survey of Austria. Jahrbuch der Geologischen Bundesanstalt 150 (1+2): 263-299.

Manuscript received: 9 June 2020

Manuscript accepted: 24 September 2020

Published on: 8 December 2020

Topic editor: Christian de Muizon

Desk editor: Danny Eibye-Jacobsen

Printed versions of all papers are also deposited in the libraries of the institutes that are members of the EJT consortium: Muséum national d'histoire naturelle, Paris, France; Meise Botanic Garden, Belgium; Royal Museum for Central Africa, Tervuren, Belgium; Royal Belgian Institute of Natural Sciences, Brussels, Belgium; Natural History Museum of Denmark, Copenhagen, Denmark; Naturalis Biodiversity Center, Leiden, the Netherlands; Museo Nacional de Ciencias Naturales-CSIC, Madrid, Spain; Real Jardín Botánico de Madrid CSIC, Spain; Zoological Research Museum Alexander Koenig, Bonn, Germany; National Museum, Prague, Czech Republic. 